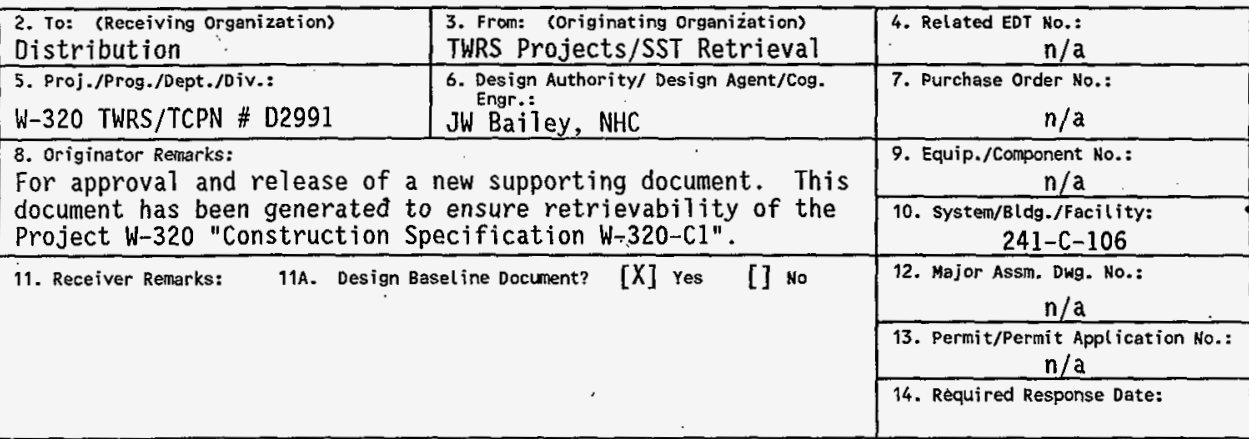

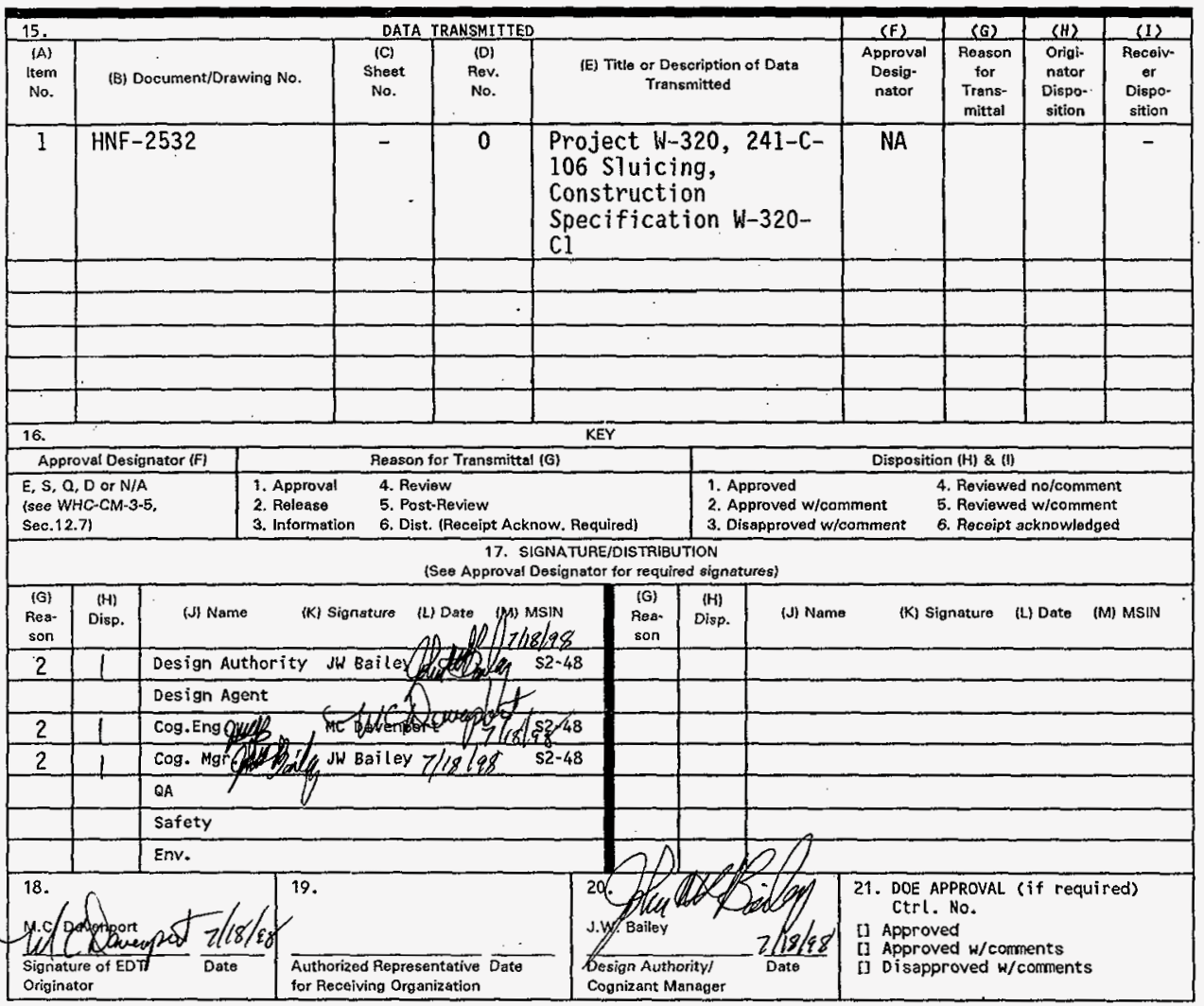




\section{Project W-320, 241-C-106 Sluicing, Construction Specification, W-320-C1}

John W. Bailey

Numatec Hanford Co., Richland, WA 99352

U.S. Department of Energy Contract DE-AC09-96RL13200

$\begin{array}{lll}\text { EDT/ECN: } & 622266 & \text { UC: } 506 \\ \text { Org Code: } & 8 C 452 & \text { Charge Code: } \text { D2991/HANA0600 } \\ \text { B\&R Code: } & \text { EW3130010 } & \text { Total Pages: } 135\end{array}$

Key Words: W-320, Sluicing, Tank 241-C-106, Tank 241-AY-102, WRSS, Specifications, Construction.

Abstract: This supporting document has been prepared to make the construction specifications for Project $W-320$, readily available.

TRADEMARK DISCLAIMER. Reference herein to any specific commercial product, process, or service by trade name, trademark, manufacturer, or otherwise, does not necessarily constitute or imply $i$ ts endorsement, recommendation, or favoring by the United states Government or any agency thereof or its contractors or subcontractors.

Printed in the United States of America. To obtain copies of this document, contact: Document Control Services, P.0. Box 950, Mailstop K6-08, Richland WA 99352, Phone (509) 372-2420; Fax (509) 376-4989.
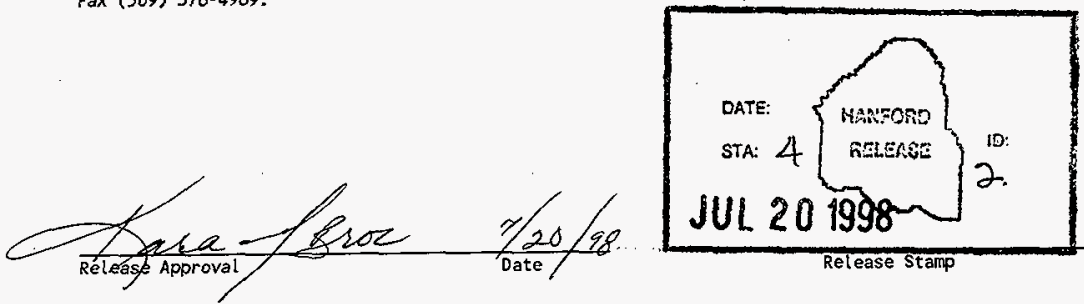

Approved for Public Release 


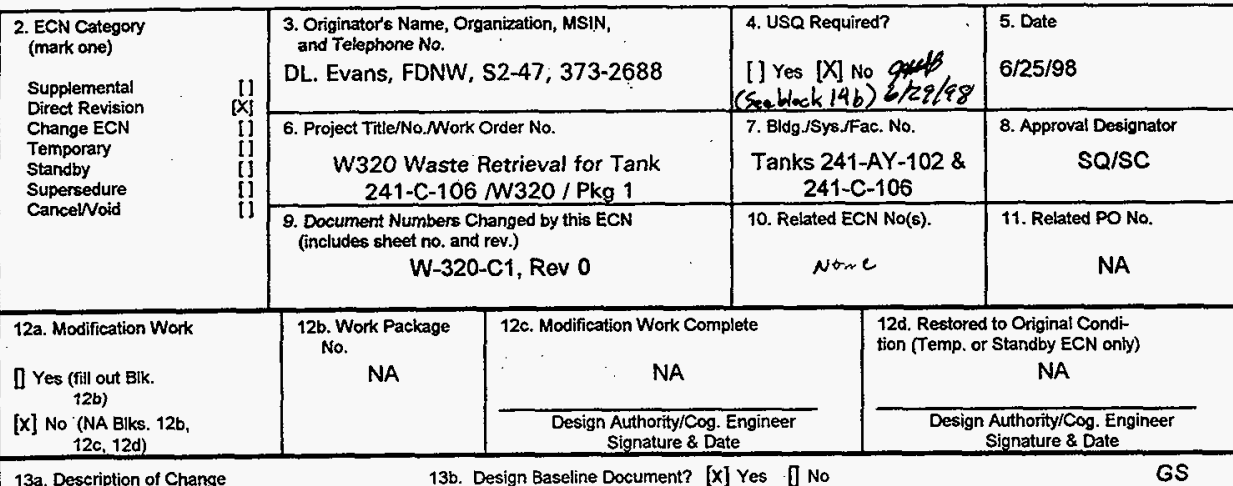

As-Built and General Revisions of the construction spectification W-320-C1. Changes to include:

Section 15493

1.3.3 change "Safety Class 2 " to "Safety Significant products"

Table PIPE CODE M-5 pages 14 \& 15 change "(Safety Class 3$)^{n}$ to "(General Service)"

Table PIPE CODE M-7 page 16 change "(Safety Class 3$)^{n}$ to "(General Service)"

Table PIPE CODE M-9 page 17 change "(Safety Class 2)" to "(Safety Significant)"

Table PIPE CODE M-26a page 18 change "(Safety Class 3)" to "(General Service)"

14a. Justification (mark one)

Criteria Change

As-Found

$[\mathrm{X}]$

Design Improvement , []

Environmenta!

Const. Error/Omission

0

Facility Deactivation

Design Error'Omission

14b. Justification Details

As-Built construction specification for project turnover.

No USQ required because categorical exciusion (TF-96-0690, Rev 2) applies.

No project calculations are affected by this work.

An independent review of this design change was performed by FDNW in accordance with HNF-PRO-445.

15. Distribution (include name, MSIN, and no. of copies)

CDC, S2-53, 1

TJ Kasnick, S2-47, 1

JW Bailey, $52-48,1$

RL Powers, S5-13, 1

Project Files, R1-29,

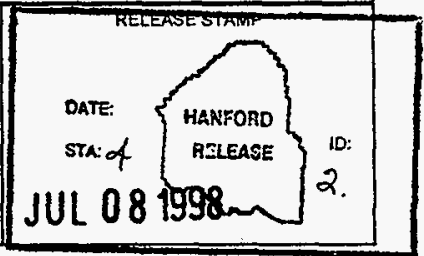




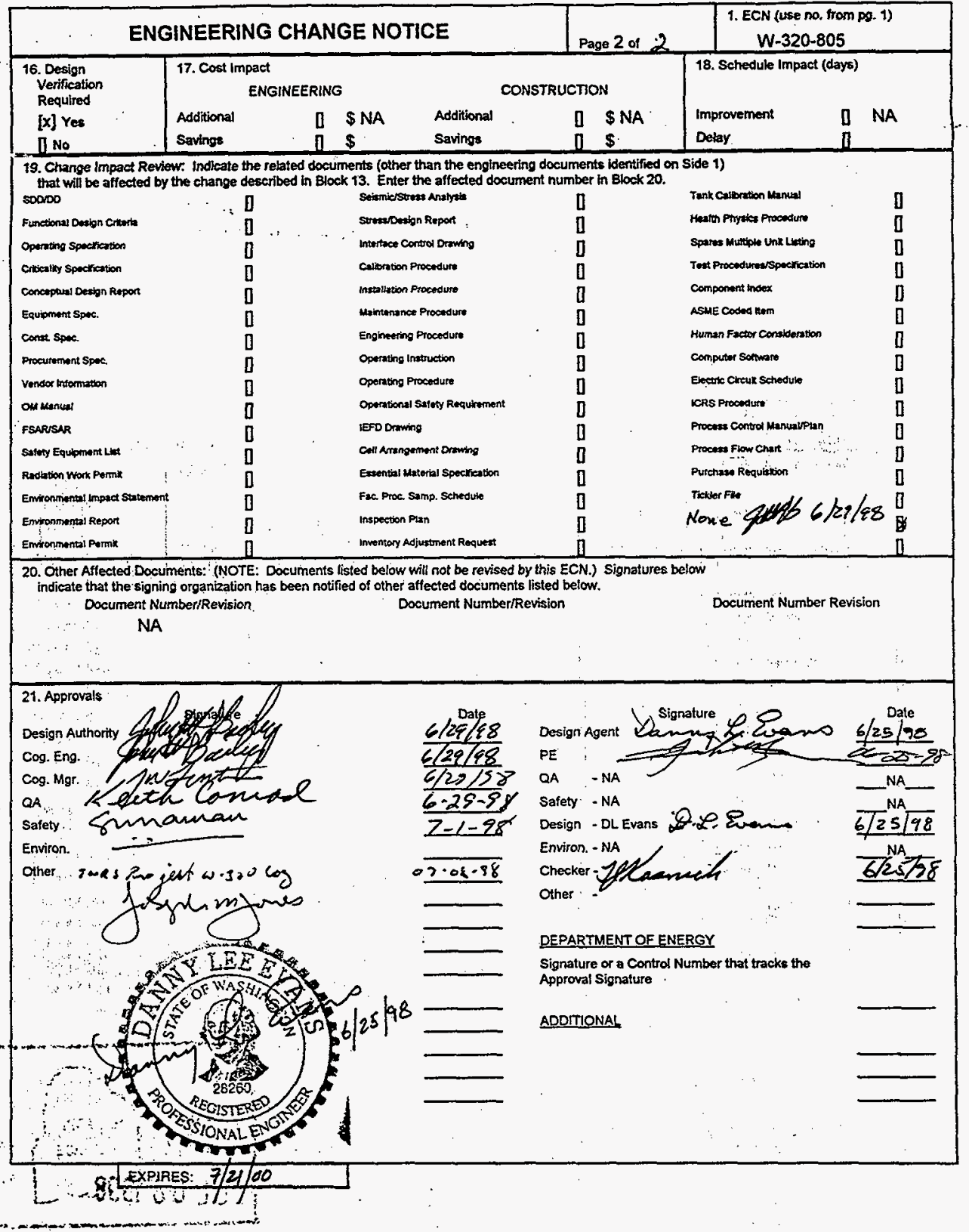




\section{AS-BUILT REV 1}

TANK 241-C-106 SLUICING

Sitework/Interfarm Piping System

Original Issue: 11/07/94

Prepared By

Fluor Daniel Northwest

Richland, Washington

For

Numatec Hanford Corporation

Contract 651005
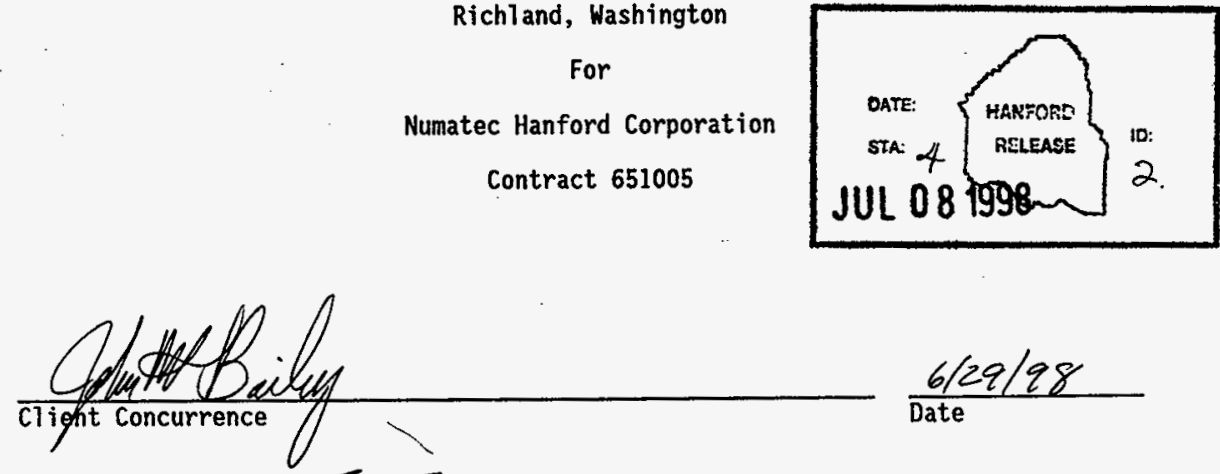

$\frac{6 / 2 q / 98}{\text { Date }}$

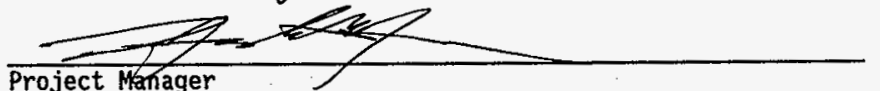

$\frac{26-25-98}{\text { Date }}$

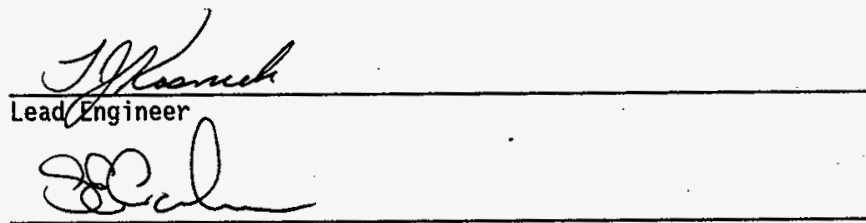

Field Concurrence
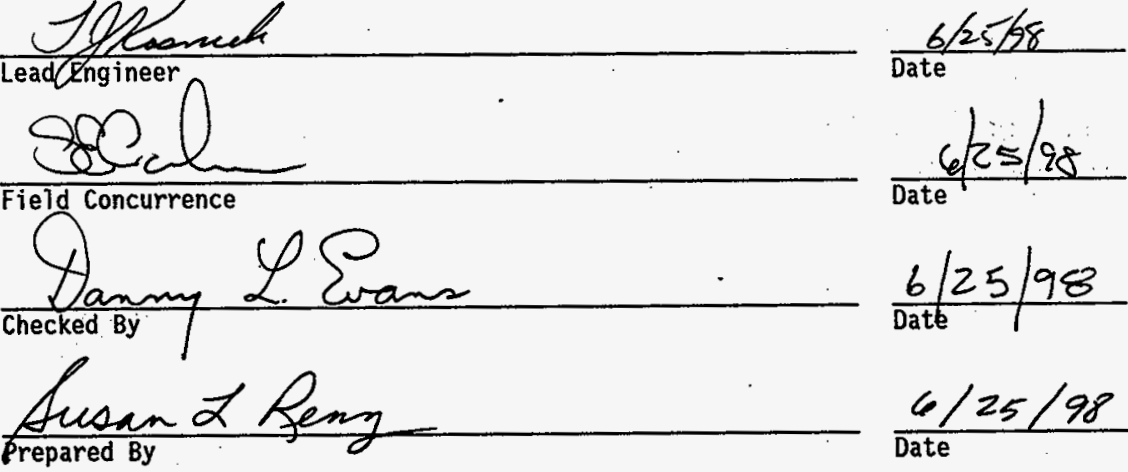

The ECNs affecting specification page attached. 
(2) Title

Tank 241-C-106 S7uicing Equipment Removal System

CHAHGE COHTROL RECORD

\begin{tabular}{|c|c|c|c|}
\hline \multirow{2}{*}{$\begin{array}{c}\text { (3) } \\
\text { Revision }\end{array}$} & \multirow{2}{*}{ (4) Description of Change - Replace, Add, and Delete Pages } & \multicolumn{2}{|c|}{ Authorized for Release } \\
\hline & & (5) Cog. Engr. & (6) Cog. Mgr. \\
\hline 0 & (7) $\quad \mathrm{H}-320-\mathrm{C} 2$, Rev. 0 , EDT 606525 & $N / A$ & $N / A$ \\
\hline 1 RS & $\begin{array}{l}\text { W-320-C2, Rev. 1, As-Built per ECN W-320-806. } \\
\text { includes incorporation of the following ECNs: } \\
W-320-068,-069,-070,-071,-077,-093 \text {, } \\
-548,-597,-806 \text {. }\end{array}$ & $\begin{array}{l}\text { DL Evans } \\
\text { X. L. Eans }\end{array}$ & MA Lane, \\
\hline & & & \\
\hline & & & \\
\hline & & & \\
\hline & & & \\
\hline . & & $\because$ & $:$ \\
\hline & & & \\
\hline$\therefore \ldots$ & $\therefore$ & : $:$ & का \\
\hline & & & \\
\hline$\therefore$ & & & $\therefore$ \\
\hline ? & & & $\therefore$ \\
\hline$\therefore \quad \therefore$ & & & $\therefore \therefore$ \\
\hline & & & $\because$ \\
\hline & $:$ & & . \\
\hline & & & \\
\hline & & & \\
\hline & $\cdot$ & & \\
\hline & & & \\
\hline & & & \\
\hline & & . & \\
\hline & & & \\
\hline & & & \\
\hline & & & \\
\hline & & & \\
\hline . & & & \\
\hline & & & \\
\hline & & & \\
\hline
\end{tabular}


The ECNs affecting specification are as follows:

ECN W-320-084

$03300-2,3$

ECN W-320-085

$15493-1,2,4,6,7,8$,

$9,12,13,17,21$

ECN $W-320-805$

$15493-3,14,15,16$,

17,18

ECN W-320-108

02650-2

ECN $H-320-111$

02200-1

$02225-2, ; 4$

ECN W-320-112

$15493-7,15$

ECN W-320-127

$15493-10,11,16,18,21$

ECN W-320-133

$02650-1,2,3$

$15493-7,14$
ECN $W-320-145$

15493-3

ECN $N-320-159$

$16640-6,11,12$

ECN $W-320-178$

02225-2

ECN $\mathrm{H}-320-197$

15500-2

ECN $\mathrm{H}-320-201$

15493-10

ECN $H-320-286$

$15500-4,5$

ECN $W-320-389$

03300-2

ECN $\mathrm{H}-320-413$

$15493-8,19,20,21,22$

ECN W-320-701

TOC $\mathrm{iii}$

$02513-1,2,3,4,5$

ECN H-320-805

$15493-3,14,15,16,17,18$ 


\section{CONSTRUCTION SPECIFICATION}

\section{TANK 241-C-106 SLUICING}

\section{Package I - Sitework/Interfarm Piping System}

Work Order ER4319

Prepared By

ICF Kaiser Hanford Company

Richland, Washington

For the US. Department of Energy Contract DE-AC06-93RL12359
OFFICIAL RELEASE $B Y$ YHW

QATIE

NOV 071994

\section{APPROVED}

TFF Kaisey Hanford Company (ICF KH)

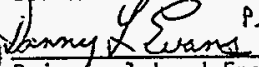

Principal Lead Enginegr

P.E. \$ZEZZOO

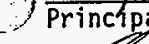

9/2

94

Ma.Tiseher

$\frac{q-28-94}{\text { Date }}$

Sáfety

Cथ Notan

Quality Engineering

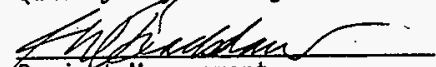

Projett Management
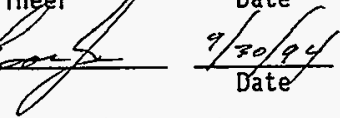

$\frac{9-30-94}{\text { Date }}$

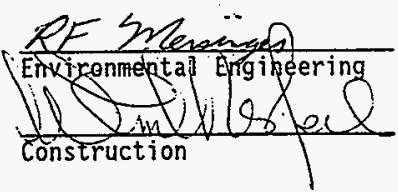

$\frac{9-27 \cdot 96}{\text { Date }}$

$\frac{9-30-94}{\text { Date }}$

Westinghouse Hanford Company (WHC)

therenthe

Projects Department WHC

RELEASED FOR CONSTRUCTION

N/A

US Department of Energy

\section{$\frac{9 / 30 / 94}{\text { Date }}$}

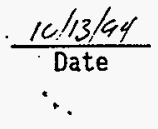

Date

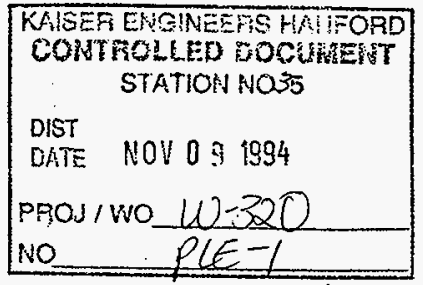


Package I - Sitework/Interfarm Piping System

Prepares by

ICF Kaiser Hanford Company

Richland, Hashington

\section{CERTIFICATION}

I certify that the indicated sections of this Specification were prepared by me or under my supervision and that I am a registered professional engineer under the laws of the State of Washington.
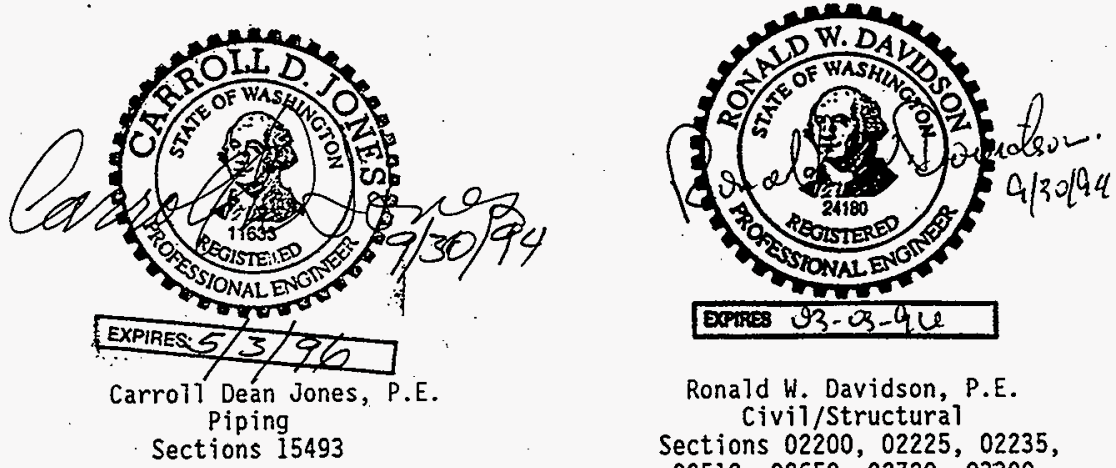

Ronald W. Davidson, P.E.

Civil/Structural

Sections 02200, 02225, 02235, $02512,02650,02720,03300$, $05500,09900,13121$

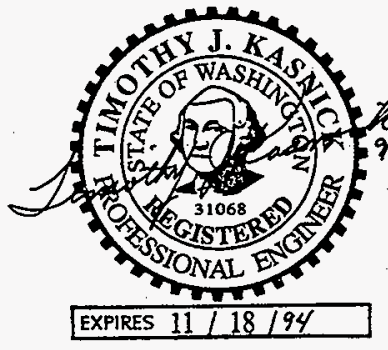

Timothy J. Kasnick, P.E. Electrical

Section 16400

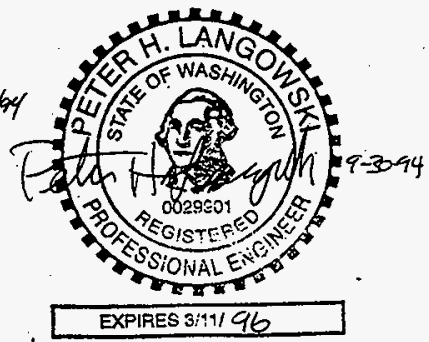

Peter H. Langowski, P.E. HVAC

Section 15500

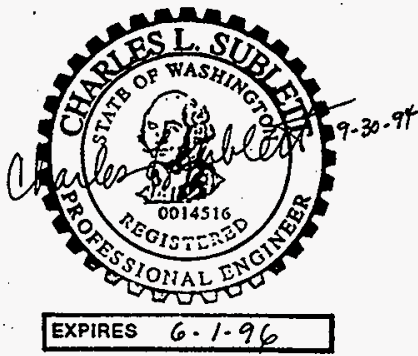

Charles L. Sublett, P.E. Cathodic Section 16640 
Title and Approval Page Certification Page

DIVISION 1 - GENERAL REQUIREMENTS

Section 01010 through Section 01720 Under Separate Cover (W-030-G2)

\begin{tabular}{|c|c|}
\hline $\begin{array}{l}\text { DIVISION } 2- \\
\text { Section } 02200 \\
\text { Section } 02225 \\
\text { Section } 02235 \\
\text { Section } 02512 \\
\text { Section } 02513 \\
\text { Section } 02650 \\
\text { Section } 02720\end{array}$ & $\begin{array}{l}\text { SITEWORK } \\
\text { Earthwork } \\
\text { Excavating, Backfilling, and Compacting for Utilities } \\
\text { Road Subgrade and Granular Base } \\
\text { Hot-Laid Asphaltic Concrete Paving } \\
\text { Cold-Laid Asphaltic Concrete Paving } \\
\text { Piped Utilities } \\
\text { Storm Sewerage }\end{array}$ \\
\hline$\frac{\text { DIVISION } 3-}{\text { Section } 03300}$ & $\frac{\text { CONCRETE }}{\text { Cast-In-Place Concrete }}$ \\
\hline$\frac{\text { DIVISION } 5}{\text { Section } 05500}$ & $\frac{\text { METALS }}{\text { MetaI Fabrications }}$ \\
\hline$\frac{\text { DIVISION } 9}{\text { Section } 09900}$ & $\frac{\text { FINISHES }}{\text { Painting }}$ \\
\hline$\frac{\text { DIVISION } 13 \text { - }}{\text { Section } 13121}$ & $\frac{\text { SPECIAL CONSTRUCTION }}{\text { Metal Building Systems }}$ \\
\hline $\begin{array}{l}\text { DIVISION } 15- \\
\text { Section } 15493 \\
\text { Appendix A } \\
\text { Section } 15500\end{array}$ & $\begin{array}{l}\text { MECHANICAL } \\
\text { Chemical Process Piping Systems } \\
\text { Identification of Piping Systems } \\
\text { Heating, Ventilating, and Air Conditioning }\end{array}$ \\
\hline $\begin{array}{l}\text { DIVISION } 16- \\
\text { Section } 16400 \\
\text { Section } 16640 \\
\text { Appendix A }\end{array}$ & $\begin{array}{l}\text { ELECTRICAL } \\
\text { Service and Distribution } \\
\text { Cathodic Protection } \\
\text { Functional Test of Reference Electrodes }\end{array}$ \\
\hline
\end{tabular}




\section{EARTHWORK}

PART 1 - GENERAL

1.1 REFERENCES

1.1.1 The following documents, including others referenced therein, form part of this Section to the extent designated herein.

1.1.1.1 American Society for Testing and Materials (ASTM)

D 653-90 Standard Terminology Relating to Soil, Rock, and Contained Fluids

1.1.1.2 Washington State Department of Transportation (WSDOT)

M 41-01-93

M 41-10-94
Construction Manua?

Road, Bridge, and Municipal Construction

\subsection{SUBMITTALS}

1.2.1 See Section 01300 of $W-030-G 2$ for submittal procedures.

1.2.2 Approval Required

1.2.2.1 Damage prevention procedure: Before excavation, submit a proposed procedure to prevent overstressing existing structures, or interrupting service to existing facilities.

1.2.3 Approval Not Required: None

PART 2 - PRODUCTS

2.1 MATERIALS

2.1.1 Obtain specified soils from excavation or other designated locations. Obtain onsite ICF KH approval for soils.

2.1.2. Fill or Backfill

2.1.2.1 Structural: Well graded soil mixtures which may contain cobbles up to 3 inches in greatest dimension if uniformly distributed and not constituting more than $20 \%$ of volume of fill.

2.1.2.2 Common: Well graded soil mixtures containing cobbles up to 8 inches in greatest dimension if uniformly distributed and not constituting more than $40 \%$ of volume of fill.

2.1.3 Stabilization: Crushed rock, with a maximum fragment size of 3/4-inch for walkways, and under 2 inches for other areas. 


\subsection{EXCAVATION}

3.1.1 Obtain an excavation permit before performing excavation. Excavation permits will be provided by ICF KH as specified in Section 01065 of W-030-G2. For additional requirements see Section 01110 of W-030-G2.

3.1.2 If cultural properties (eg, bones, artifacts) are encountered during excavation, stop work and notify ICF KH. ICF KH and the Hanford Cultural Resources Laboratory will assess the significance of the find.

3.1.3 Locate and expose underground utilities by hand tools. Use of heavy equipment and machinery requires approval by ICF KH.

3.1.4 Wherever slopes of excavations will intersect existing underground 1ines or structures such as building foundations, underground piping, electrical ducts or direct buried electrical lines, install shoring or other means of support to prevent overstressing existing structure or underground lines or to prevent interrupting service to existing buildings.

\subsubsection{Footings and Foundations}

3.1.5.1 Make excavations for footings to depth shown on the Drawings or additional depth necessary to provide undisturbed surface to receive footing. Make excavations to proper width with allowances made for forms and bracing. Make bottom of excavations compact, level, true, and free of loose material.

3.1.5.2 If over-excavation occurs where footings are designed to be placed on undisturbed earth, correct at time of placing concrete by extending concrete down to undisturbed earth, or by placement of backfill, compacted as specified in 3.2.1.2b, Method $\mathrm{C}$.

\subsubsection{In Situ Soils}

3.1.6.1 Salvage in situ stabilization material and reuse for backfilling and compacting. Contact ICF KH acceptability for backfill material, if required.

3.1.6.2 In-place density tests will be conducted by ICF KH on in situ soils, using nuclear density gage, during excavation. Results of tests will be used by ICF KH for testing compaction of backfill.

3.1.6.3 Excavated material containing concentrations of radioactive materials that can be detected by portable survey instruments normally used for performing radiation surveys is considered contaminated, and shall be sampled and analyzed for content.

3.1.6.4 Excavated material containing radioactive contamination shall be packaged. ICF KH will dispose of the packaged, contaminated soil. 
3.1.7 Where stabilization is required, finish subgrade 3 inches below Page $^{3}$ elevations shown on the Drawings. Stabilize berm as shown on the Drawings.

\subsection{PLACEMENT}

\subsubsection{Fill and Backfill}

\subsubsection{General:}

a. Backfill Permit: Do not start fill or backfill without an approved permit as required by Section 01065 of $\mathrm{W}-030-\mathrm{G} 2$.

b. Remove debris and organic matter from the area to be filled or backfilled.

c. Use only specified materials for fill or backfill. Keep materials free of frozen particles, lumps, organic matter, and trash.

d. Do not place fill or backfill on frozen ground.

e. Filling or backfilling by sluicing or flooding with water will not be permitted.

f. Bring fill or backfill up eventy on sides of walls, structures, and utility lines to avoid unbalanced loading.

g. Do not place fill or backfill against concrete structure or foundation wall less than 14 days after completion of structure or wall unless written permission from ICF KH is obtained. Provide: wall support, where noted on the Drawings, before filling or backfilling.

\subsubsection{Compaction:}

a. Before placement of fill or backfill, demonstrate to ICF KH by physical test at the worksite, that the procedure proposed for placement and compaction of soils will provide the degree of compaction specified. Prepare "Soil Compaction Procedure," Form KEH-0382, in accordance with the instructions.

b. Place backfill in accordance with WSDOT $M$ 41-10, Section 2-03.3(14)C and approved procedure as follows.

1) Use Method C under foundations and slabs.

2) Use Method B under pavements and roads, and within 5 feet of buildings, fences, other structures, or poles supporting electric lines or pipe.

3) Use method specified in 3.2.1.3 to the height specified on the Project Drawings for the berm.

c. Compaction control tests will be in accordance with WSDOT M 41-10, Section 2-03.3(14)D. 


\subsubsection{Common:}

a. Place fill or backfill in layers not more than 12 inches thick, loose measurement.

b. Compact each layer, full width, by at least 1 pass of vibratory or rammer type compactor, pneumatic-tired roller, loaded scraper wheel, grader wheel, or power roller.

c. Mound over top layer of backfill to depth of 1 inch for each

12 inches of trench depth to maximum mound height of 6 inches.

\subsubsection{In situ soils:}

a. Compact backfill by depositing soils in 8 inch Tayers and compacting to density equal to in situ density determined by tests made during excavation. Maintain uniformity of compaction throughout backfi11.

b. Do not use soils containing rocks Targer than 3 inches in greatest dimension for compacted backfili.

\subsubsection{Finish Grading and Stabilization}

3.2.2.1 Rake areas disturbed by work, remove surface stones larger than 6 inches and dispose of excess material and debris at an area designated by ICF $\mathrm{KH}$.

3.2.2.2 Stabilize areas disturbed by work with a 3-inch course of crushed rock specified in 2.1.3. Finish stabilization course to elevations shown on the Drawings.

3.3 FIELD QUALITY CONTROL

3.3.1 Soil Compaction Tests: Sampling and testing of compacted fill and backfill will be performed by ICF KH. Frequency of testing shall be in accordance with WSDOT $\mathrm{M}$ 41-01, page 9-52. 
(KEH-382) 


\section{(KEH-382R)}

END OF SECTION 
EXCAVATING, BACKFILLING, AND COMPACTING FOR UTILITIES

PART 1 - GENERAL

\subsection{REFERENCES}

1.1.1 The following documents, including others referenced therein, form part of this Section to the extent designated herein.

1.1.1.1 American Society for Testing and Materials (ASTM)

D 653-90 Standard Terminology Relating to Soil, Rock, and Contained Fluids

1:1.1.2 Washington State Department of Transportation (WSDOT)

M 41-01-93

Construction Manua 1

M 41-10-94

Road, Bridge, and Municipal

Construction

\subsection{SUBMITTALS}

1.2.1 See Section 01300 of $W-030-G 2$ for submittal procedures.

\subsubsection{Approval Required}

1.2.2.1 Damage prevention procedure: Before excavation, submit a proposed procedure to prevent overstressing existing structures, or interrupting service to existing facilities.

1.2.3 Approval Not Required: None

PART 2 - PRODUCTS

\subsection{MATERIALS}

2.1.1 Obtain specified soils from excavation or other designated locations. obtain onsite ICF KH approval for soils.

\subsubsection{Fill or Backfill}

2.1.2.1 Structural: Well graded soil mixtures which may contain cobbles up to 3 inches in greatest dimension if uniformly distributed and not constituting more than $20 \%$ of volume of fill.

2.1.2.2 Common: Well graded soil mixtures containing cobbles up to 8 inches in greatest dimension if uniformly distributed and not constituting more than $40 \%$ of volume of fill. 
HNF-2532, Rev.0, Pg 8

2.1.3 Bedding for Underground Pipe, Conduit, Cable, and Culvert: Sandageas defined in ASTM D 653, or excavated sandy material having less than $20 \%$ gravel particles, with those particles having a maximum dimension of 1/2-inch.

2.1.4 Stabilization: Crushed rock, with a maximum fragment size of 3/4-inch for walkways, and under 2 inches for other areas.

2.1.5 Plastic Sheet-Marker. 6 inch wide nondeduct ible tape impointed with a warning, sUCh-as "CAUTION BURIEQ INSTALLATION BELOW", at intervats of 4-feet-maximum; Reef-Industries nTerpa Tape."

2.1.5 Plastic Sheet Maker: 2-inch wide, minimum, detectable tape imprinted with a warning, such as "CAUTION - BURIED WATER LINE BELOW" OR "CAUTION - BURIED PIPELINE BELOW" at intervals of 4 feet maximum; Seton Identification Products, or approved substitute.

PART 3 - EXECUTION

\subsection{EXCAVATION}

3.1.1 Obtain an excavation permit before performing excavation. Excavation permits will be provided by ICF KH as specified in Section 01065 of W-030-G2. For additional requirements see Section 01110 of W-030-G2.

3.1.2 If cultural properties (eg, bones, artifacts) are encountered during excavation, stop work and notify ICF KH. ICF KH and the Hanford Cultural Resources Laboratory will assess the significance of the find.

3.1.3 Locate and expose underground utilities by hand tools. Use of heavy equipment and machinery requires approval by ICF KH.

3.1.4 Where slopes of excavations will intersect existing underground lines or structures such as building foundations, underground piping, electrical ducts or direct buried electrical lines, instal1 shoring or other means of support to prevent overstressing existing structures or underground lines or prevent interrupting service to existing buildings.

3.1.5 Make excavations to line and grade shown on the Drawings and wide enough to make connections. Excavate with near vertical sides from bottom of trench up to 1 foot above pipe, conduit, cable, and culvert. Excavate trench deep enough to permit placement of compacted bedding, 4 inches minimum thickness, beneath pipe, conduit, cable, and culvert except where excavation is in undisturbed sand which will serve as bedding or where lines are to be encased in concrete. Pare holes in trench bottoms for pipe couplings so pipe will bear full length of barrel or section. Excavate Trench for Transfer Lines deep enaugh for 6 inches of compacted bedding.

3.1.6 Install shoring to hold materials and surcharge pressure for full depth of trench.

3.1.7 Keep trenches free of standing water when laying is in progress. 
HNF-2532, Rev.0, Pg. 9

3.1.8 If over-excavation occurs, correct by placement of structural bBasf 11 . 
3.1.9.1 Salvage in-situ stabilization material and reuse for backfilling and compacting. Do not use or reuse contaminated material. Contact ICF KH for backtiil material, if required.

3.1.9.2 In-place density tests will be conducted by ICF KH on in-situ soils, using nuclear density gage, during excavation. Results of tests will be used by ICF KH for testing compaction of backfill.

3.1.9.3 Excavated material containing concentrations of radioactive materials that can be detected by portable survey instruments normally used for performing radiation surveys is considered contaminated, and shall be sampled and analyzed for content.

3.1.9.4 Excavated material containing radioactive contamination shall be packaged. ICF KH will dispose of the packaged, contaminated soil.

3.1.10 Where stabilization is required, finish subgrade 3 inches below elevations shown on the Drawings.

3.2 PLACEMENT

3.2.1 Fill and Backfill

3.2.1.1 General:

a. Backfill Permit: Do not start fill or backfill without an approved permit as required by Section 01065 of W-030-G2.

b. Remove debris and organic matter from the area to be filled or backfilled.

c. Use only select materials for fill or backfill. Keep materials free of frozen particles, lumps, organic matter, and trash.

d. Do not place fill or backfill on frozen ground.

e. Filling or backfilling by sluicing or flooding with water will not be permitted.

f. Bring fill or backfill up evenly on sides of walls, structures, and utility lines to avoid unbalanced loading.

g. Backfill the Transfer Line Trench by pushing material parallel to the trench; not by side filling. Backfilling from the side is permissible after the ICF KH has demonstrated that a sufficient depth of backfill has been placed to prevent lateral pipe movement, and damage.

\subsubsection{Compaction:}

a. Before placement of fill or backfill, demonstrate to ICF KH by physical test at the worksite, that the procedure proposed for placement and compaction of soils will provide the degree of compaction specified. 
Prepare "Soil Compaction Procedure", Form KEH-0382, in accordance with Page 11 the instructions.

b. Place backfill in accordance with WSDOT $M$ 41-10, Section $2-\hat{u} 3.2(14) C$ and approved procedure as follows.

1) Use Method $\mathrm{C}$ under pipelines.

2) Use Method B within 5 feet of buildings, fences, other structures, or poles supporting electric lines or pipes.

c. Compaction control tests will be in accordance with WSDOT M 41-10, Section 2-03.3(14)D.

\subsubsection{Common:}

a. Place fill or backfill in layers not more than 12 inches thick, loose measurement.

b. Compact each layer, full width, by at least 1 pass of vibratory or rammer type compactor, pneumatic-tired roller, loaded scraper wheel, grader wheel, or power roller.

c. Mound over top Tayer of backfill to depth of 1 inch for each

12 inches of trench depth to maximum mound height of 6 inches.

3.2.1.4 Underground piping, conduit, cable, and culvert trenches:

a. Bedding placed beneath pipe, conduit, cable, and culvert in trenches shall be material specified in 2.1.3. Place an addionat 6 -inches of beding above Transfer-tines?

b. Place and compact bedding in trench prepared as specified in 3.1 .5 before laying pipes, conduits, cables, and culverts. Compact bedding as specified for structural backfill. Compact bedding and backfill

materials of Transfer Lines to $98 \%$ 95\% of WSDOT 46-01, Section 600, Test Method 606. Do not compact within 5 feet of any buried utility of ECN-111 unknown type or any utility which may be susceptible to damage from compaction efforts. This pertains primarily to process lines, identified on the Drawings.

c. Place backfill over joints in underground pipes only after pressure testing of line has been completed.

d. Backfill under conduit and haunches of pipe, around sides, and up to 1 foot above top of pipe, conduit, cable, and culvert using bedding material specified in 2.1.3. Place and compact material same as specified for structural backfill. Compact with care, to avoid misalignment of pipe and provide uniform bearing along barrel of pipe.

e. Backfill trenches from elevation 1 foot above top of pipe, conduit, cable, and culvert as follows. 
1) Use structural fill or backfill in locations specified in Page 12 3.2.1.2.

2) Use common fill or backfill as specified in 3.2.1.3 for other locations.

f. Do not allow heavy construction equipment to pass over buried lines until at least 2 feet of backfill has been placed over the 7 ine or until bridging has been placed across trenching and approved by ICF KH.

3.2.1.5 In situ soils:

a. Compact backfill by depositing soils in 8 inch layers and compacting to density equal to in-situ density determined by tests made during excavation. Maintain uniformity of compaction throughout backfill.

b. Do not use soils containing rocks larger than 3 inches in greatest dimension for compacted backfili.

3.2.2 Plastic Sheet Marker: Place continuously and directly over buried utility lines, 1 foot below finish grade. Place markers over each outside line of multiple lines, if spacing permits. Place intermediate markers spaced 4 feet maximum.

3.3 FIELD QUALITY CONTROL

3.3.1 Soil Compaction Tests: Sampling and testing of compacted fill and backfill will be performed by ICF KH. Frequency of testing shall be in accordance with WSDOT M 41-01, page 9-52. 
SOIL COMPACTION PROCEDURE

(KEH-382) 
INSTRUCTIONS

HNNF-2532, Rev.0

Page 14

(KEH-382R)

END OF SECTION 


\section{ROAD SUBGRADE AND GRANULAR BASE}

\section{PART 1 - GENERAL}

\subsection{REFERENCES}

1.1.1 The following documents, including others referenced therein, form part of this Section to the extent designated herein.

1.1.1.1 Washington State Department of Transportation (WSDOT)
M 41-01-93
Construction Manual
M 41-10-94
Road, Bridge, and Municipal
Construction

1.2 SUBMITTALS: Not Used

PART 2 - PRODUCTS

2.1. MATERIALS

2.1.1 Subgrade Fill and Backfill

2.1.1.1 Obtain specified soils from excavation or other designated locations. obtain onsite ICF KH approval for soils.

2.1.1.2 Fill or backfill: Well graded soil mixtures which may contain cobbles up to 3 inches in greatest dimension if uniformly distributed and not constituting more than $20 \%$ of volume of fil1.

2.1.2 Granular Base

2.1.2.1 Base course: WSDOT M 41-10, Section 9-03.9(3), Base Course Classification.

2.1.2.2 Leveling course: WSDOT M 41-10, Section 9-03.9(3), Top Course Classification.

2.1.2.3 Crushed gravel shoulder: Same as leveling course.

PART 3 - EXECUTION

\subsection{EXCAVATION}

3.1.1 Before performing excavation, obtain an excavation permit. Excavation permits will be provided by ICF KH in accordance with Section 01065 of W-030-G2.

3.1:2 If cultural properties (eg, bones, artifacts) are encountered during excavation, stop work and notify ICF KH. ICF KH and the Hanford Cultural Resources Laboratory will assess the significance of the find. 
3.1.3 If over-excavation occurs, correct by placement of backfill.

3.2 PLACEMENT

3.2.1 Subgrade Filling and Backfilling

3.2.1.1 Remove debris and organic matter from area to be filled or backfilled.

3.2.1.2 Use only specified materials for fill or backfill. Keep materials free of frozen particles, lumps, organic matter and trash.

3.2.1.3 Do not place fill or backfill on frozen ground.

3.2.1.4 Filling or backfilling by sluicing or flooding with water will not be permitted.

3.2.2 Fill or Backfill

3.2.2.1 Before placement of fill or backfill, demonstrate to ICF KH by physical test at the worksite, that the procedure proposed for $\mathrm{p}$ ? acement and compaction of soils will provide the degree of compaction specified. Prepare "Soi] Compaction Procedure" Form KEH-0382, in accordance with the instructions.

3.2.2.2 Place backfill under roads in accordance with WSOOT M 41-10, Section 2-03.3(14)C, Method B and approved procedure.

\subsubsection{Granular Base}

3.2.3.1 Before placement of granular base, demonstrate to ICF KH by physical test at the worksite, that the procedure proposed for $\mathrm{placement}$ and compaction of base will provide the degree of compaction specified. Prepare "Soil Compaction Procedure" Form KEH-0382, in accordance with the instructions.

3.2.3.2 Construction Requirements: Construction shall be in accordance with following sections of WSDOT M 41-10.

a. Subgrade: Section 2-06.3.

b. Equipment: Section 4-04.3(1).

c. Mixing: Section 4-04.3(3).

d. Placing and spreading: Section 4-04.3(4).

e. Miscellaneous requirements: Section 4-04.3(7).

f. Weather limitations: Section 4-04.3(8).

g. Hauling: Section 4-04.3(9). 
a. Final shaping before compacting shall be accomplished using approved equipment.

b. Compaction control tests wi1l be in accordance with WSDOT M 41-10, Section 2-03.3(14)D.

3.2.3.4 Shoulders: Construct shoulders, of width shown on the Drawings, after placement of asphaltic wearing course.

3.2.4 Finish Grading and Stabilization: Rake area disturbed by work, remove surface stones larger than 6 inches and dispose of excess material and debris at area designated by ICF KH.

$3.3 \quad$ FIELD QUALITY CONTROL

3.3.1 Sampling and testing of compacted fill and backfill will be performed by ICF KH. Frequency of testing shall be in accordance with WSDOT M 41-01, page 9-52. 
(KEH-382) 
INSTRUCTIONS

(KEH-382R)

END OF SECTION 


\section{HOT-LAID ASPHALTIC CONCRETE PAVING}

\section{PART 1 - GENERAL}

\subsection{REFERENCES}

1.1.1 The following documents, including others referenced therein, form part of this Section to the extent designated herein.

1.1.1.1 American National Standards Institute (ANSI)

$$
\text { D6.1-1988 }
$$

Manual on Uniform Traffic

Control Devices for Streets and Highways

1.1.1.2 Washington State Department of Transportation (WSDOT)

M 41-10-94 Road, Bridge, and Municipal

\section{Construction}

\subsection{SUBMITTALS}

1.2.1 See Section 01300 of W-030-G2 for submittal procedures.

1.2.2 Approval Required

1.2.2.1 Laboratory reports: Before delivery, submit laboratory test reports for the following.

a. Asphalt: Show that asphalt used meets the requirements of $A R-4000 \mathrm{~W}$ in accordance with WSDOT M 41-10, Section 9-02.1(4).

b. Aggregate: Show that aggregate used meets the requirements of Sections 9-03.8(2) and 9-03.8(6). Include rice density as established by WSDOT M 41-10, Method 705 .

1.2.3 Approval Not Required: None

PART 2 - PRODUCTS

\subsection{MATERIALS}

2.1.1 Asphalt: In accordance with WSDOT M 41-10, Sections 9-02.1(2) and 9-02.1(4). Grade of paving asphalt for use in asphaltic concrete mixture shall be AR-4000W. Grade of liquid asphalt for prime coat shall be MC- 250 .

2.1.2 Aggregate: Class "B" in accordance with WSDOT M 41-10, Section 9-03.8(1), (2), and (3)B.

2.1.3 Blending Sand: In accordance with WSDOT M 41-10, Section 9-03.8(4). 
2.1.4 Mineral Filler: In accordance with WSDOT M 41-10, Section 9-03.8(5). Page 21

\section{$2.2 \quad$ MIXES}

2.2.1 Proportioning of Asphalt Concrete Materials: In accordance with WSDOT M 41-10, Section 9-03.8(6) Class " $B$ " asphalt concrete.

PART 3 - EXECUTION

$3.1 \quad$ APPLICATION

3.1.1 Perform work in accordance with the following sections of WSDOT M 41-10.

3.1.1.1 Asphalt mixing plants: Section 5-04.3(1).

3.1.1.2 Hauling equipment: Section 5-04.3(2).

3.1.1.3 Asphalt pavers: Section 5-04.3(3).

3.1.1.4 Rollers: Section 5-04.3(4).

3.1.1.5 Existing surface conditioning: Section 5-04.3(5).

3.1.1.6 Asphalt material heating: Section 5-04.3(6).

3.1.1.7 Aggregate preparation: Section 5-04.3(7).

3.1.1.8 Mixing: Section 5-04.3(8).

3.1.1.9 Spreading and finishing: Section 5-04.3(9).

3.1.1.10 Compaction: Section 5-04.3(10).

3.1.1.11 Joints: Section 5-04.3(11).

3.1.1.12 Samples: Section 5-04.3(12).

3.1.1.13 Surface smoothness: Section 5-04.3(13).

3.1.1.14 Heating-planing bituminous pavement: Section 5-04.3(14).

3.1.1.15 Weather 1imitations: Section 5-04.3(16).

3.1.1.16 Asphalt change in grade: Section 5-04.3(18).

3.1.1.17 Driving surface sealing: Section 5-04.3(19).

3.1.2 Permanent Signing: In accordance with ANSI D6.1, Section II and WSDOT M 41-10, Section 8-21.

3.1.3 Pavement Marking: In accordance with ANSI D6.1, Section III and WSDOT M 41-10, Section 8-22. 
3.2.1 Sampling and testing of pavement witl be performed by ICF KH. Frequency of sampling shall be in accordance with WSDOT M 41-01, page 9-52.

$3.3 \quad$ PROTECTION

3.3.1 Traffic Control: Institute and maintain in accordance with WSDOT $M$ 41-10, Section 1-07.23, Subsections (1) through (4).

END OF SECTION 
SECTION 02513

HNF-2532, Rev.0

\author{
COLD-LATD ASPHALTIC CONCRETE PAVING
}

PART 1 - GENERAL

\title{
1.1 REFERENCES
}

1.1.1 The following documents and other referenced therein form part of Contract to extent designated this Section.

1.1.1.1 American National Standards Institute (ANSI)

D6.1-1998

Manual on Uniform Traffic Control Devices for Streets and Highways

1.1.1.2 American Society for Testing and Materials (ASTM)

D 4318-93

Test Method for Liquid Limit, plastic Limit, and Plasticity Index of Soils

1.1.1.3 Fluor Daniel Northwest (FDNW) TWRS Project Procedures Manual (PPM)

Section $2.10 \quad$ Technical Document Control

1.1.1.4 Washington State Department of Transportation (WSDOT)

M 41-10-94

Road, Bridge, and Municipa]

Construction

1.2 SUBMITTALS

1.2.1 See FDNW PPM Section 2.10 for submittal procedures.

1.2.2 Approval Required

1.2.2.1 Asphalt mix certification: Before mixing, submit certification that asphalt mix is in accordance with WSDOT $M$ 41-10 for each car load or other lot of asphalt at time of delivery.

1.2.3 Approval Not Required: None

1.3 SITE CONDITIONS

1.3.1 Install aspha7tic mixture only when weather is clearing or fair. Ensure that surface receiving asphaltic mixture is $50^{\circ} \mathrm{F}$ or greater.

PART 2 - PRODUCTS

2.1 MATERIALS 
2.1.1 Aggregate: WSDOT M 41-10, Section 9-03.8. Ensure that at least $50 \%$ contains fractured face. Grade aggregate as follows.

\section{Sieve}

$5 / 8$ inch square openings

$1 / 2$ inch square opening

$1 / 4$ inch square opening

US No. 10

US No. 200

Asphait
Percentage by Weight Passing Sieves

100

$90-100$

$55-75$

$32-48$

$3-7$

$2.5-5.5$

2.1.2 Asphalt: WSDOT M 41-10. Section 9-02.1(2). MC-250.

\subsubsection{Binder}

2.1.3.1 Use silica sand or crushed stone. Ensure the following gradation.

\section{Sieve}

$3 / 8$ inch square openings

$1 / 4$ inch square opening

US No. 200
Percentage by Weight Passing Sieves

100

$90-100$

10-15

2.1.3.2 Portion passing US No. 40 sieve shall have 7iquid limit of 30 or less and plasticity index of 3 or less when tested in accordance with ASTM D 4318.

\subsection{MIXES}

2.2.1 Proportioning: Contractor shall proportion asphaltic mixture.

2.2.2. Preparation of Material

2.2.2.1 Before proportioning materials, heat aggregate to temperature of 175 to $275^{\circ} \mathrm{F}$. Use rotary heater or drier. Ensure that heater or drier is equipped with fan and dust collector for excess dust removal.

2.2.2.2. Heat asphalt to temperature of 93 to $116^{\circ} \mathrm{C}\left(200\right.$ to $\left.240{ }^{\circ} \mathrm{F}\right)$. Use insulated tank, kett7e, or sump. Ensure that tank, kettle, or sump is designed to provide controlled, uniform heating. Prevent flame from coming into contact with tank, kettle, or sump.

\subsubsection{Mixing}

2.2.3.1 Mix in pug mill. 
2.2.3.2 Place hot aggregate in mixer. After placement of aggregate, add hot asphalt and mix for 30 seconds or as much 7onger as necessary to produce blended mixture.

2.2.3.3 Maintain baich weight within mixer's rated capacity.

2.2.4 Hauling and Stockpiling

2.2.4.1 Use dump trucks for hauling. Before loading mixture, lubricate sides and bottoms of trucks with mixture of water and either light oil or diesel oil. Ensure that truck is free of excess water and oil.

2.2.4.2 Clear stockpile sites of vegetation, trees, brush, rocks, and other debris. Nake uniform ground surface before depositing material.

PART 3 - EXECUTION

3.1 PREPARATION

3.1.1 Sweep aspha7tic surfaces which will receive mixture. Remove loose materials from holes and raveled areas. Cut back overhanging and irregular edges to stable material to form straight lines.

3.1.1.2 Backfill trenches and large holes extending through pavement to base and leveling courses. Use backfill material which is equal to existing construction. Compact backfill materials to density equal to adjacent, undisturbed material as determined by Construction Engineer.

3.1.1.3 Add water to secure compaction. Leave allowance for placement of asphaltic mixture equal to existing surface depth, or 2 inches, whichever is greater.

3.1.1.4 Before application, obtain approval of compaction.

\subsection{APPLICATION}

3.2.1 Asphalt Mix

3.1.2.1 Spread mixture by motor grader or spreader box of design approved by Construction Engineer.

3.1.2.2 Ensure that mixture is in plastic, workable condition when applied to repair area.

3.1.2.3 Where segregation of 7arger pieces of aggregate occurs on surface, correct after first rolling of pavement.

3.1.2.4 Use hand methods to install and finish areas which are inaccessible to grader or spreader box. 


\subsubsection{Compaction:}

a. Immediately the following spreading, compact by rolling with 3-wheeled or tandem power roller weighing at least 8 tons. Compression wheels on 3-wheeled rollers shall be at least 20 inches wide and be shaped or set so rolling surfaces conform with crown specifjed for finished pavement. Start rolling at edges and proceed toward center of pavement. Overlap on successive trips by $1 / 2$ to $3 / 4$ width of 3-wheel roller near wheel. Alternate trips of roller shall be slightly different lengths. Continue rolling until roller marks are eliminated. Roll pavement diagonally in at least 1 direction with tandem roller of sizes described above.

b. Roll areas not accessible to roller of sizes specified in this Section with smaller power roller having weight on rear wheel(s) of at least $175 \mathrm{lb} / \mathrm{in}^{2}$ of roller width. Roll as specified above except that diagonal rolling may be omitted where impracticable.

c. Rollers shall be capable of reversing without backlash and kept in continuous motion, as nearly as practicable, so all parts of pavement receive equal compression. Rollers shall not be left standing on freshly rolled asphaltic mixture.

d. Surface of mixture after compression shall be smooth and true to establish section and grade. Mixture showing excess or deficiency of cement, or uneven distribution of cement due to insufficient mixing, or becomes mixed with dirt or defective, shall be removed and replaced with fresh mixture, and immediately compacted to conform with adjacent surfacing. Compact areas inaccessible to rollers by tamping with iron tampers.

e. Complete rolling of mixture before dark, therefore deposit no mixture on roadway that cannot be rolled before dark.

f. When required by Construction Engineer, backrol7 previous day's work.

\subsubsection{Surface smoothness:}

a. Surface of finished wearing course shall be of uniform texture, smooth, true to crown and grade, and free of defects, and shall blend smoothly into existing surface. Maximum deviation of surface when tested with 10-foot straight edge parallel to centerline of roadway, shall not exceed $1 / 4$ inch. No portion of finished pavement shall be more than $1 / 4$ inch below template cut to crown of existing surfacing, or cross-section drawings showing required corrections, placed on course at right angles to centerline. 
b. Deviations in excess of tolerances shall be corrected by addition or removal of asphaltic material and rolling or tamping.

3.1.3 Road Shoulders: If roadway repair raises pavement edge, add shoulder material to restor shoulders flush with pavement edge. slope shoulders to match existing shoulder slope and compact shoulders to firm, unyielding surface.

PROTECTION

3.3.1 When ordered by Construction Engineer, erect suitable signs and barricades meeting requirements of ANSI D6.1 Part VI. Maintain signs and barricades in place until material has set

sufficiently to allow traffic. Obtain approval of Construction Engineer before removing signs and barricades.

END OF SECTION

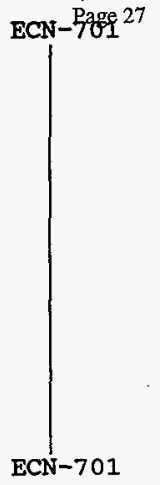




\section{PIPED UTILITIES}

PART 1 - GENERAL

1.1 REFERENCES

1.1.1 The following documents, including others referenced therein, form part of this Section to the extent designated herein.

1.1.1.1 American National Standards Institute (ANSI)

2535.1-1991

Safety Color Code for Marking Physical Hazards

1.1.1.2 American Water Works Association (AWWA)

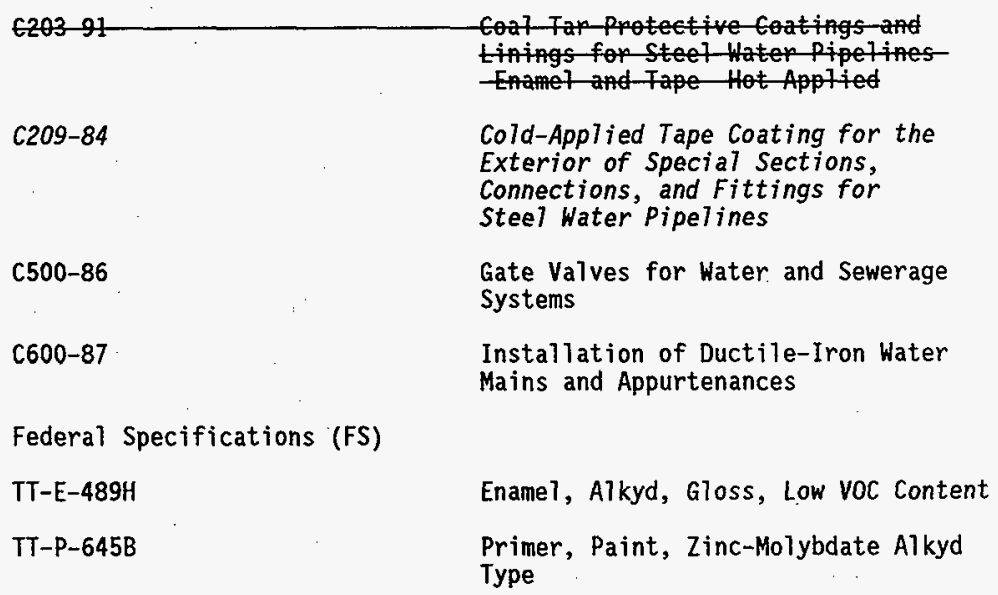

1.1.1.4 International Association of Plumbing and Mechanical officials (IAPMO)

UPC Uniform Plumbing Code

1.1.1.5 Steel Structures Painting Council (SSPC)

SP 3-91 Power Tool Cleaning

SP 6-85 Commercial Blast Cleaning

ECN-133

1.2 SUBMITTALS

1.2.1 See Section 01300 of $W-030-G 2$ for submittal procedures. 
1.2.2 Approval Required

1.2.2.1 Leak/Pressure test procedures: Before testing, submit procedures outlining proposed methods of testing joints in piping systems.

1.2.3 Approval Not Required: None 
1.3.1 Misrepresented Products: See Section 01400 of W-030-G2 for required measures to prevent the use of misrepresented products.

1.3.2 Deliverable Documentation: See Section 15493.

1.4 DELIVERY, STORAGE, AND HANDLING

1.4.1 See Section 01610 of $W-030-G 2$ for general requirements.

PART 2 - PRODUCTS

2.1 SUBSTITUTES

2.1.1 See Section 01630 of W-030-G2 for substitution approvals.

\subsection{MATERIALS}

2.2.1 Pipe and Fittings: See Pipe Code $\mathrm{M-5}$, Section 15493 and details on drawings.

2.2.1.1 Coating for carbon steel piping exposed to earth backfill: Meet or exceed the requirements of AWWA C209 exterior protective coating, consisting of cold-applied primer and Type III prefabricated tape.

2.2.2 Post Indicator Valve (PIV)

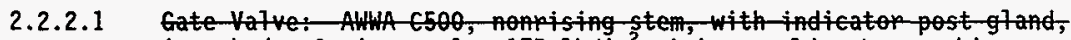
iron boly, 0 - ping seals, $175 \mathrm{lb}$ in ${ }^{2}-\mathrm{minimum}$ cold watep-working pressure, $350-16$ in? AWWA $\mathrm{C500}$, flange by flange, resilient wedge, nonrising stem, with indicator post gland, iron body, 0-ring seals, $17516 /$ in $n^{2}$ minimum cold water working pressure, $350 \mathrm{lb} / \mathrm{in}^{2}$ minimum hydraulic test pressure. ECN-108

2.2.2.2 Indicator post: Adjustable, telescoping barrel type with locking handle and clearly visible, position indicator sign plates, protected by nonbreakable plastic windows. Post shall be matched for assembly to gate valve.

2.2.2.3 Valve position supervisory 1 imit switch for installation on post indicator valve: Tamperproof and designed for use intended. Switch shall be operated during first 2 revolutions of handle in closing direction.

2.2.2.4 Tapping Sleeve: 12 by 4 inch epoxy coated steel, Mueller No. H-616.

2.2.3 Pipe Joint Sealant for Threaded Joints: Pipe compound with Teflon by Bostik Manufacturing, part No. NPBT-8.

2.2.4 Exterior Protective Coating: AWWA C203 9.

ECN-133

2.2.5 Primer: FS TT-P-645; National Lead No. 200-41. 
2.2.6 Paint: FS TT-E-489, Class A, Composition G. Colors in accordance with Page 31 ANSI 2535.1 
PART 3 - EXECUTION

\subsection{INSTALLATION}

3.1.1. General

3.1.1.1 Install piping and piping accessories in accordance with the IAPMO UPC, the Pipe Codes, the Drawings, and this Section.

3.1.1.2 Keep piping systems clean during work. Once fabrication has started on length of pipe, plug or cap open ends when installation is not in progress.

3.1.1.3 Where piping is laid in trench, trench shall be free of frost or frozen earth and standing water.

3.1.2 Carbon Steel Pipe

3.1.2.1 After cutting, ream pipe to nominal inside diameter. Remove burrs from mating threads in threaded piping before assembly.

3.1.2.2 Close or butt nipples are not permitted.

3.1.2.3 Make joints in threaded piping systems with specified joint sealant.

Apply sealant to male threads only.

3.1.3 . Exterior Protective-Couting!-See-Section 15493.Exterior Protective Coating:

ECN-133

ECN-133

3.1.3.1 Prepare carbon steel surfaces by sandblasting in accordance with SSPC $S P$ 6. Where blasting is impracticable, as determined by the Construction Engineer, clean by power wire brushing in accordance with SSPC SP 3.

3.1.3.2 Apply exterior protective coating consisting of cold-applied primer and and prefabricated tape to joints, fittings, and lengths of carbon steel pipe which will be buried in accordance with AWWA C209 and manuf acturer's instructions.

3.1.3.3 After application, test field-applied exterior protective coating materials.

a. Use electric holiday detector in accordance with AWWA C209, Section 4.4.2.

b. Repair damage to coating such as missed places of holidays in accordance with AWWA C209, Section 3.4 .

3.1.4 Install PIV in accordance with AWWA C600, the Drawings, and this Section.

3.1.5 Install post barricades around post indicator valve in accordance with the Drawing and this Section. 
3.1.6 Painting and Marking

3.1.6.1 Surface preparation of materials receiving paint shall be in accordance with SSPC-SP3.

3.1.6.2 Paint upper barrel of indicator post with 1 coat of primer and 2 coats of yellow enamel.

3.1.6.3 Paint entire length of each barricade post with primer and above grade portion with 2 coats of yellow enamel.

3.1.6.4 Color: In accordance with ANSI Z53.1.

3.1.6.5 Painting of instrument air line stub-ups will be done by others.

3.2 FIELD QUALITY CONTROL

3.2.1 Flushing: See Section 15493.

3.2.2 Hydrostatic Pressure Testing: See Section 15493.

END OF SECTION 


\section{STORM SEWERAGE}

PART 1 - GENERAL

\subsection{REFERENCES}

1.1.1 The following documents, including others referenced therein, form part of this Section to the extent designated herein.

1.1.1.1 Washington State Department of Transportation (WSDOT)

M 41-10-94 Road, Bridge, and Municipal Construction

1.2 SUBMITTALS: Not Used

PART 2 - PRODUCTS

\subsection{MATERIALS}

2.1.1 Culvert Pipe: WSDOT M 41-10, Section 9-05.4, steel pipe and arch.

\subsubsection{Drainage Structures}

2.1.2.1 Precast concrete catch basins: WSDOT M 41-10, Section 9-12.5.

PART 3 - EXECUTION

\subsection{INSTALLATION}

\subsubsection{Culverts}

3.1.1.1 P1acing steel: In accordance with WSDOT M 41-10, Section 7-02.3(1)B.

\subsubsection{Drainage Structures}

3.1.2.1 Inlets and catch basins in accordance with WSDOT M 41-10, Section 7-05.3.

3.1.2.2 Adjust catch basins to grade in accordance with WSDOT M 41-10, Section 7-05.3(1). 


\section{CAST-IN-PLACE CONCRETE}

PART 1 - GENERAL

\subsection{REFERENCES}

1.1.1 The following documents, including others referenced therein, form part of this Section to the extent designated herein.

1.1.1.1 American Concrete Institute (ACI)

$117-90$

301-89

306.1-90

318-89 (Revised 1992)

$S P-66-88$
Tolerances for Concrete Construction and Materials

Structural Concrete for Buildings

Cold Weather Concreting

Building Code Requirements for Reinforced Concrete

ACI Detailing Manual

1.1.1.2 American Society for Testing and Materiais (ASTM)
A $615-92 b$
Deformed and Plain Billet-Steel Bars
A $853-91$
for Concrete Reinforcement
C 33-92a
Steel Wire, Carbon, for General Use
C 94-92a
Concrete Aggregates
C $150-92$
Ready-Mixed Concrete
C $260-86$
Portland Cement
C 1107-91a
Air-Entraining Admixtures for Concrete
Packaged Dry, Hydraulic-Cement Grout (Nonshrink)
D. $994-71(1982)$
Preformed Expansion Joint Filler for Concrete (Bituminous Type)

1.1.1.3 Code of Federal Regulations (CFR)

Title 40

Part 249
Protection of Environment

Guidel ine for Federal Procurement of Cement and Concrete Containing Fly Ash 
SS-SS-1996
Sealer, Water and Weather Resistant for Asphalt, Concrete and Masonry Surfaces

1.1.1.5 National Ready Mixed Concrete Association (NRHCA)

Certificate of Conformance for Concrete Production Facilities
Certification of Ready Mixed Concrete Production Facilities

1.1.1.6 Washington State Department of Transportation (WSDOT)

M 41-10-94

Road, Bridge, and Municipal Construction

\subsection{SUBMITTALS}

1.2.1 See Section 01300 of W-030-G2 for submittal procedures.

1.2.2 Approval Required

1.2.2.1 Formwork: Before installation, submit fabrication drawings in accordance with ACI 301 , Sections 4.1 and 4.2. Formwork design and details shall meet the requirements of $A C I 301$, Chapter 4.

1.2.2.2 Block-Oiagram:-Before-installation of forms, stbmit block-diagram of scheduted conerete poups. Itentify pours.

ECN-389

ECN-389

$1.2 .2 .3-2$ Gertifiel-Hateriat Fest Repopts! Before-defirery, submit mantacturep's centified test reports showing-chemical analysis and physical tests made-on the particular heat op heats of steel from-which reinforcement-was-manufactured. Furnish-separate eertificutes fop-ach grotip of items furnished by each-suppliep.

1.2.2.4 Brawings: Before delivery, submit completeinforcing steet fabricution and installation drawings based on the block diagram, in accordance with $A C I-301$, Section 5.1 , including splices not-shown on the Drawings. Reinforeement details shal7 comply with ACI 318 and SP 66 .

1.2.2.53 2 Facility Certification: Before mixing, submit a current legible copy of the NRMCA "Certificate of Conformance for Concrete Production Facilities." The Certificate shall be validated by the signature and seal of a registered Civil Engineer, and the signature of the principal company executive.

1.2.2.64 3 Concrete Data: Before mixing, submit concrete materials, mix design, and mix proportions, in accordance with ACI 301 , Sections 3.8 and 16.7.3. Identify each material to be used in concrete, including the amount, by weight, to be utilized in each yd of plastic mix.

1.2.2.75 4 Curing Procedure: Before mixing, submit a description of materials and methods of curing, in accordance with ACI 301, Section 12.2.
$\left.\right|_{\mathrm{ECN}-084} ^{\mathrm{ECN}-084}$

$\mathrm{ECN}-389$

ECN-389

ECN-84

ECN-84

ECN-84 
1.2.2.86 5 Cold Weather Concreting: Before placement, submit the procedure soks specified in 3.2.2.5, if concrete will be placed during cold weather. If it will not, submit a statement to that effect.

1.2.2.97 6 Hot Weather Concreting: Before placement, submit the procedure $\mathrm{ECN}-84$ specified in 3.2 .2 .5 , if concrete will be placed during hot weather. If it wil] not, submit a statement to that effect.

1.2.3 Approval Not Required: None ECN-84

1.2 .3 .1 Guning-Procelure:-Beforemixing, stbmita deseription of matemiats and methods of etring, in accordance with-ACI 301, section-12.2.

\subsection{QUALITY ASSURANCE}

1.3.1 Contractor's Quality Assurance Program: See Section 01400 of W-030-G2.

1.3.2 Misrepresented Products: See Section 01400 of W-030-G2 for required measures to prevent the use of misrepresented products.

1.3.3 Deliverable Documentation: The following documents and records, required by this Section, shall be delivered to ICF KH in accordance with Section 01720 of W-030-G2.

Document

Pour STip and Trip Tickets

\section{Paragraph}

3.2.2.2

1.4 DELIVERY, STORAGE, AND HANDLING

1.4.1 See Section 01610 of W-030-G2 for general requirements.

PART 2 - PRODUCTS

2.1. SUBSTITUTES

2.1.1 See Section 01630 of W-030-G2 for substitution approvals.

2.2 MATERIALS

2.2.1 Concrete

2.2.1.1 Cement: ASTM C 150, Type II (low alka7i). Fly Ash content is allowable in accordance with the recommendations of 40 CFR 249.12 and 249.13.

2.2.1.2 Aggregates: ASTM C 33, 3/4 inch maximum size.

2.2.1.3 Air-entraining admixture: ASTM C 260; Sika Chemical Company "SIKA AER", Chem-Masters Corporation "Adz-Air", or Protex Industries "AES."

2.2.1.4 Properties:

a. Minimum allowable compressive strength: $40001 \mathrm{~b} / \mathrm{in}^{2}$ at 28 days. 
b. STump: 4 inches in accordance with ACI 301 , Section 3.5 .

c. Air content: In accordance with ACI 301, Table 3.4.1.

d. Proportions: In accordance with ACI 301, Sections 3.8 and 3.9 .

2.2.1.5 Mixing: In accordance with ASTM C 94.

2.2.1.6 Delivery: In accordance with ASTM C 94.

2.2.2 Reinforcing Stee

2.2.2.1 Steel bars: ASTM A 615, deformed, Grade 60 .

2.2.2.2 Tie wire: ASTM A 853 carbon steel, 0.062-inch (16-gage) minimum, annealed.

2.2.3 Joint Materjals

2.2.3.1 Epoxy resin: In accordance with WSDOT M 41-10, Section 9-26, Type II, Grade 2, Class B or C; QCM Company EAS8 Class A, Adhesive Engineering "Concresive 1001 LPL," or Protex Industries "Probond 822."

2.2.3.2 Expansion joint filler: ASTM 0994.

2.2.3.3 Sealant: FS TT-S-00230, Type II.

2.2.4 Nonshrink Grout: ASTM C 1107; Sika Corporation "Sika Grout 212," or Master Builders "Masterflow 713."

2.2.5 Forms: Wood, stee1, plywood, or Masonite Corporation "Concrete Form Presdwood", as required for various specified finishes.

2.2.6 Form Coating Materials: Symons Corporation "Magic Kote," AC Horn Incorporated "Form Shield," or Burke Company "Burke Release No. 1."

PART 3 - EXECUTION

3.1. PREPARATION

3.1.1 Form Construction

3.1.1.1 Insta71 formwork in accordance with ACI 301 , Section 4.2 and approved submittals. Interior shape and rigidity shall be such that finished concrete will meet the requirements of the Drawings within tolerances specified in ACI 117, Section 4.

3.1.1.2 Prepare form surfaces in accordance with ACI 301, Section 4.4 using specified form coating materials, or as described below.

3.1.1.3 Forms for surfaces which will be permanently concealed from view may be saturated with water, before placing concrete, instead of other treatment. In freezing weather forms shall be treated with oil or stearate. 
3.1.1.4 Clean forms of foreign material before placing concrete.

\subsection{INSTALLATION}

\subsubsection{Reinforcing Steel}

3.2.1.1 Fabricate bars to dimensions shown on the Drawings, within tolerances shown in ACI 301, Section 5.6 .

3.2.1.2 Tag in accordance with the bar list.

3.2.1.3 Place as shown on approved drawings, within tolerances specified in ACI 117, Section 2.2.

3.2.1.4 Tie to prevent displacement during placement of concrete.

3.2.1.5 Do not force into concrete after initial set has started.

3.2.1.6 Place with the concrete protection dimension equal to the minimum given in ACI 301, Section 5.7, except where shown otherwise on the Drawings.

\subsubsection{Concrete}

3.2.2.1 Before batching, obtain approval of form work and reinforcement by ICF $\mathrm{KH}$.

\subsubsection{Before placing:}

a. Obtain ICF KH approval of the "Pour Slip." The "Pour Slip" shall include identification of sections of structure to be placed, maximum size of coarse aggregate, and design strength. Obtain "Pour slip" forms from ICF $\mathrm{KH}$.

b. For each truck load, deliver the "Trip Ticket" to ICF KH. "Trip Tickets" shall contain information 7 isted in ASTM C 94, Paragraphs 16.1.1 through 16.1.10, and the water/cement ratio.

3.2.2.3 Place in accordance with ACI 301, Sections 8.1, 8.2, and 8.3. Do not drop (free fall) more than 5 feet. Insert vibrator, vertically if possible, into concrete and reach small distance into concrete in next lower layer. Do not insert vibrators into lower courses that have reached initial set. Take care to avoid allowing head of vibrator to come in contact with forms, reinforcement, or embedded items.

3.2.2.4 Temper only as permitted in ACI 301, Section 7.5.

3.2.2.5 Place nonshrink grout where shown on the Drawings, in accordance with manufacturer's recommendations.

3.2.2.6 Weather conditions: Protect concrete during placement in accordance with ACI 301 , Sections 7.6 and 8.4. Cold weather concreting procedure shall be in accordance with ACI 306.1 . 
3.2.2.7 Construction joints: Make in accordance with ACI 301, Section 6.1, andPage 40 as detailed on the Drawings. Coat joints with epoxy resin, where shown on the Drawings, in accordance with manufacturer's recommendations.

3.2.2.8 Embedded icilli: Install in accordance with ACI 301, Sections 6.4 and 6.5 .

3.2.2.9 Expansion joints: Make in accordance with ACI 301, Section 6.2 and details on the Drawings.

3.2.2.10 Placing concrete against earth: Place on or against firm, damp surfaces free of frost, ice and free water. Do not place until required compaction has been obtained. Dampen earth surfaces to receive fresh concrete.

3.2.2.11 Consolidation: Consolidate concrete slabs in accordance with ACI 301 , Section 11.6.

3.2.3 Form Removal and Concrete Repair

3.2.3.1 Form removal: Remove in accordance with ACI 301, Section 4,5.

3.2.3,2 Cut back form ties and examine concrete surfaces for defects. Repair only after permission for patching is given by ICF KH.

3.2.3.3 Place concrete repair mortar within one hour after mixing. Do not retemper mortar.

3.2.3.4 Repair surface defects in accordance with ACI 301, Sections 9.1, 9.2, and 9.3. Cure concrete repairs the same as new concrete.

3.2.4 Concrete Finishes and Tolerances

3.2.4.1 Formed surfaces: Start finishing following concrete repair and complete within 96 hours after forms have been removed. Finish in accordance with the following ACI 301 sections.
a. Surfaces exposed to earth backfill
b. Interior surfaces
Section 10.2.2
c. Exterior surfaces
exposed to weather
Section 10.2.2
d. Related unformed surfaces
Section 10.5
e. Surfaces to receive special protective coating
Section 10:2.1
Section 10.3 .2

3.2.4.2 Unformed surfaces: Finjsh in accordance with the following ACI 301 sections.

a. Interior floors

Section 11.7 .3 
b. Exterior equipment slabs

c. Exterior slabs subject to

Section 11.7 .4

3.2.5 Sealant

3.2.5.1 Perform sealing using specified materials and proper tools in accordance with the manufacturer's recommendations.

3.2.5.2 Do not apply exterior sealing material when ambjent temperature is below 40 or above $100^{\circ} \mathrm{F}$.

3.2.5.3 Apply materials with guns having proper size nozzles. Use sufficient pressure to fill spaces and voids. Where use of gun is impractical, approved hand tools may be used.

\section{$3.3 \quad$ CURING}

3.3.1 Cure concrete in accordance with ACI 301, Section 12.2. Clear curing compounds shall be tinted or appljed to surfaces marked to show the extent of spraying.

3.3.2 Do not use curing compound on surfaces to receive flooring or special protective coating.

3.4 FIELD QUALITY CONTROL

3.4.1 Concrete Testing: ICF KH will sample and test concrete to ACI 301 , Sections $16.3 .4,16.3 .5,16.3 .6$ and 16.3 .8 .

\section{$3.5 \quad$ PROTECTION}

3.5.1 Protect concrete during extreme weather conditions in accordance with ACI 301 , Section 12.3 .

3.5.2 Protect concrete from mechanical damage in accordance with ACI 301 , Section 12.4.

END OF SECTION 


\section{METAL FABRICATIONS}

\section{PART 1 - GENERAL}

\subsection{REFERENCES}

1.1.1 The following documents, including others referenced therein, form part of this Section to the extent designated herein.

1.1.1.1 American Society of Mechanical Engineers (ASME)

B\&PVC

Section IX
Boiler and Pressure Vessel Code, 1992 Edition

Welding and Brazing Qualifications

1.1.1.2 American Society for Testing and Materials (ASTM)

A 36-91

A $106-91$

A $193-92$

A 194-92a

A 240-92b

A $276-92$

A $307-92 a$

A 500-90a

A 563-92a

A 569-91a
Structural Steel

Seamless Carbon Steel Pipe for High-Temperature Service

Alloy-Steel and Stainless Steel Bolting Materials for High-Temperature Service

Carbon and Alloy Steel Nuts for Bolts for High-Pressure and High-Temperature Service

Heat-Resisting Chromium and Chromium-Nickel Stainless Steel Plate, Sheet and Strip for Pressure Vessels

Stainless and Heat-Resisting Steel Bars and Shapes

Carbon Steel Bolts and Studs, 60000 PSI Tensile Strength

Cold-Formed Welded and Seamless Carbon Steel Structural Tubing in Rounds and Shapes

Carbon and Alloy Steel Nuts

Steel, Carbon, Hot-Rolled Sheet and Strip Commercial Quality 


\section{F 436-92 \\ F $844-90$}

1.1.1.3 American Welding Society (AWS)

A2.4-93

D1.1-92
Hardened Steel Washers

Washers, Steel, Plain (Flat), Unhardened for General Use

\subsection{SUBMITTALS}

1.2.1 See Section 01300 of W-030-G2 for submittal procedures.

1.2.2 Approval Required

1.2.2.1 Drawings: For metal fabrications not shown on manufacturer's data sheets submit fabrication drawings and bill of materials prior to fabrication. Include plans, elevations, details, sections, and connections. Show thickness, type, grade, class of metal, fasteners, anchorage, and accessory items where applicable. Weiding and examination symbols shall be in accordance with AWS A2.4

1.2.2.2 Manufacturer's data: Before delivery, submit copies of manufacturer's specifications, dimensioned diagrams, anchor details, and installation instructions for manufactured items.

1.2.3. Approval Not Required

1.2.3.1 Commercial Grade Item Documentation: Before fabrication/ installation, submit reports of inspections and tests of items specified in 2.3.1.

1.3 QUALITY ASSURANCE

1.3.1 Contractor's Quality Assurance Program: See Section 01400 of W-030-G2.

1.3.2 Misrepresented Products: See Section 01400 of W-030-G2 for required measures to prevent the use of misrepresented products.

1.3.3 Welding Qualification

1.3.3.1 Qualification of welding personnel and procedures: Personnel and procedures for welding structural steel shall have been qualified in accordance with AWS D1.1 before welding. Qual ification in accordance with ASME Section IX may be substituted for this requirement.

1.3.3.2 Extent of application: The above qualification requirements also apply for preliminary fabrication of parts, from materials specified in 2.2, when fabrication is accomplished in shops other than the material suppliers shops, but not necessarily at the worksite. 
1.3.4 Deliverable Documentation: The following documents and records, required by this Section, shall be delivered to ICF KH in accordance with Section 01720 of H-030-G2.

\section{Document}

Expansion Anchor Inspection Results

\section{raragraph}

3.5 .2

1.4 DELIVERY, STORAGE, AND HANDLING

1.4.1 See Section 01610 of $W-030-G 2$ for general requirements.

PART 2 - PRODUCTS

\subsection{SUBSTITUTES}

2.1.1 See Section 01630 of $W-030-G 2$ for substitution approvals.

2.2 MATERIALS

2.2.1 Rolled Steel Shapes, Plates, and Bars: ASTM A 36.

2.2.2 Steel Pipe: ASTM A 106, Grade B, Schedule 80.

2.2.3 Steel Tubing: ASTM A 500, Grade B.

2.2.4 Steel Sheet and Strip: ASTM A 569.

2.2.5 Stainless Steel Plate, Sheet, and Strip: ASTM A 240 TP 304L.

2.2.6 Staintess Steel Bars and Shapes: ASTM A 276 TP 304L.

\subsubsection{Fasteners}

2.2.7.1 Bolts: ASTM A 307, Grade A or B.

2.2.7.2 Nuts: ASTM A 563, Grade A, heavy hex.

2.2.7.3 Washers: ASTM F 844, circular.

2.2.7.4 High Strength Bolts: ASTM A 193, Grade B8.

2.2.7.5 High Strength Nuts: ASTM A 194, Grade 8F.

2.2.7.6 High Strength Washers: ASTM F 436.

2.2.7.7 Expansion anchors: Hilti Fastening Systems "Kwik-Bolt II," or ITH-Ramset "Trubolt Wedge Anchor."

2.2.8 We]ding Electrodes: E70XX.

2.2.9 Nonshrink Grout: See Section 03300.

2.2.10 Paint: See Section 09900. 
2.2.11 Zinc-rich coating: Southern Coating Incorporated "Galvicon", or ZRC Page 45 Products Company "ZRC."

2.2.12 Isolating Tape: Inmont Corporation No. 162.03 Elastic Compound Tape, or Products Research and Chemical Corporation "Kling-Felt No. 213."

2.2.13 Supports: Interchangeable channels, channel spring nuts, and bolts; Unistrut Corporation "Unistrut.".

2.2.13:1 Channels: Sizes as specified on Drawings.

2.2.13.2 Channel spring nuts: Manufacturer's standard.

2.2.13.3 Bolts (for use with channel spring nuts): Manufacturer's standard.

2.2.14 Support Clamps (for rigid steel conduit): Manufacturer's standard.

2.3. FABRICATION

2.3.1 General

2.3.1.1 Verify measurements and take field measurements necessary before

fabrication. Provide miscellaneous bolts and anchors, supports, braces, and connections necessary for completion of metal fabrications. Cut, reinforce, dri71, and tap metal fabrications shown to receive finish hardware and similar items. Weld or bolt connections as shown on the Drawings.

2.3.1.2 Workmanship: Form metal fabrications to shape and size, with sharp lines, angles, and true curves. Drilling and punching shall produce clean, true lines and surfaces. Execute and finish work in accordance with fabrication drawings.

2.3.1.3 Jointing and intersections: Accurately made, tightly fitted, and in true planes with adequate fastenings.

2.3.1.4 Perform welding of steel connections in accordance with AWS D1.1.

2.3.2 Miscellaneous Steel Items: Supply required clips, frames, equipment supports, and other fabrications not specified, but shown on the Drawings. Fabricate parts from standard structural sections or shapes, to sizes required. Wherever miscellaneous parts are exposed, grind edges, corners, and rough cuts smooth and free of snags. Shop paint parts except those to be embedded in concrete or masonry, or those which require other specific finishes.

\subsubsection{Finishes}

2:3.3.1 Prime ferrous metal in accordance with Section 09900. Do not coat members to be embedded in concrete or masonry, surfaces and edges to be field welded, or jtems to be galvanized. 


\subsection{EXAMINATION}

3.1.1 Examine areas where metal fabrications are to be installei and notify ICF KH in writing of conditions detrimental to proper and timely completion of work. Do not proceed with work until unsatisfactory conditions have been corrected.

3.2.1 Prepare setting drawings, diagrams, templates, and instructions for installation of anchorages, such as concrete inserts, anchor bolts, and miscellaneous items having integral anchors, to be embedded in concrete or masonry construction.

\subsection{INSTALLATION}

3.3.1 Install expansion anchors in accordance with the manufacturer's recommendations.

3.3.2 Install metal fabrications plumb, level or as shown on the Drawings.

3.3.3 Make field connections as neatiy as possible with joints flush and smooth. Grind smooth exposed field welds and polish before field painting. Repair welds in galvanized work with 2 coats of zinc-rich coating.

3.3.4 Where dissimilar metals are in contact, or where aluminum is in contact with concrete, mortar, masonry, wet or pressure-treated wood, or absorptive materials subject to wetting, protect surfaces with isolating tape to prevent galvanic or corrosive action.

3.3.6 Torque bolts used with channel spring nuts in support channels and clamps as follows.

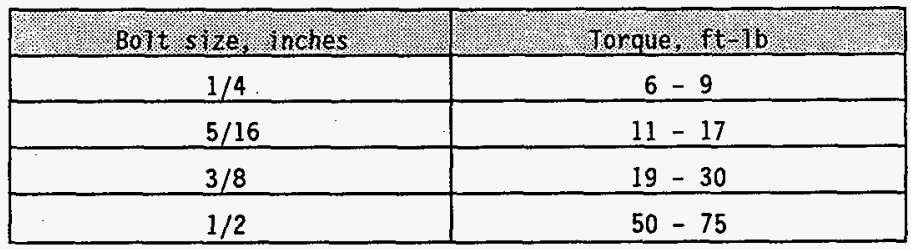

\section{$3.4 \therefore \quad$ APPLICATION}

3.4.1 After installation has been approved, clean and paint connections with primer. Touch-up shop prime coat wherever damaged.

$3.5 \quad$ FIELD QUALITY CONTROL

3.5.1 Expansion Anchor Installations: ICF KH wiTl inspects safety class I and 2 installations and randomly inspect Safety Class 3 and 4 installations. 


\section{PAINTING}

\section{PART 1 - GENERAL}

\subsection{REFERENCES}

1.1.1 The following documents, including others referenced therein, form part of this Section to the extent designated herein.

1.1.1.1 Painting and Decorating Contractors of America (PDCA)

Architectural Specification $\quad 1984$

Manual

\subsection{SUBMITTALS}

1.2.1 See Section 01300 of W-030-G2 for submittal procedures.

1.2.2 Approval Required

1.2.2.1 List of materials: Before delivery, submit 1ist including manufacturers' names, specifications, recommendations, and other data necessary to show compliance with requirements.

1.2.2.2 Color samples: Before delivery, submit samples in form of 3 by 5 -inch color chips. Describe coating material, manufacturer, and color identification on reverse face of each chip. Colors will be selected by ICF KH. Retain one set of approved samples at site for use as quality standard of final finishes.

\subsubsection{Approval Not Required: None}

\subsection{QUALITY ASSURANCE}

1.3.1 Use manufacturers and products 1isted in the PDCA Architectural Specification Manual, Chapter 7.

1.4 DELIVERY, STORAGE, AND HANDLING

1.4.1 See Section 01610 of $W-030-G 2$ for general requirements. Store materials indoors.

\section{$1.5 \quad$ PROJECT CONDITIONS}

1.5.1 Environmental Requirements

1.5.1.1 Temperature: Uniess otherwise recommended by paint manufacturer, apply coatings when ambient and surface temperatures are 45 to $95^{\circ} \mathrm{F}$, except for water-thinned paints and other special coatings.

a. Apply water-thinned paints when ambient and surface temperature is 50 to $90^{\circ} \mathrm{F}$. 
b. Provide temporary heat as required until specified surface and air Page 48 temperatures exist for required time periods. Maintain temporary heat for 24 hours after paint and finish application.

1.5.1.2 Weather: Do no exterior work on unprotected surfaces if it is raining or moisture from other source is present or expected before applied finishes can dry or attain proper cure without damage.

a. Allow surfaces to dry and attain required temperatures and conditions specified before proceeding with work or continuation of previously started work.

b. Do not apply finish in areas where dust is being generated.

c. Humidity: Follow manufacturer's directions for extremes.

1.5.1.3 Ventilation: Provide adequate continuous ventilation required for drying various materials as recommended by the manufacturer.

1.5.1.4 Illumination: Provide temporary lighting to attain minimum surface lighting level of $15 \mathrm{fc} / \mathrm{ft}^{2}$.

PART 2 - PRODUCTS

2.1 SUBSTITUTES

2.1.1 See Section 01630 of W-030-G2 for substitution approvals.

\subsection{MATERIALS}

2.2.1 Furnish materials identified in PDCA Architectural Specification Manual, Chapters 5,6 , and 7 for systems scheduled in 3.5 .

2.2.2 Furnish ready-mixed materiats.

PART 3 - EXECUTION

3.1 EXAMINATION

3.1.1 Examine surfaces scheduled to receive finish for conditions that will adversely affect execution, permanence, or quality of work and which cannot be put into acceptable condition through preparatory work specified in 3.2 .

3.1.2 Report conditions that may affect proper application of finish, in writing, to ICF KH. Do not begin surface preparation or coating application until defects have been corrected, and conditions are made suitable. 


\subsection{PREPARATION}

3.2.1 Protection

3.2.1.1 Protect finished work of other trades and the following.

a. Metal siding on walls.

b. Materials having complete factory finish, such as electrical switchplates, lighting fixtures, and finish hardware.

3.2.1.2 As work proceeds, and upon completion of work, promptly remove spills, splashes, or splatters from products by methods not damaging to affected surfaces.

3.2.1.3 Repair or replace surfaces damaged by painting work as directed by ICF KH.

\subsubsection{Surface Preparation}

3.2.2.1 Prepare surfaces for finish systems specified in accordance with recommendations of finish material manufacturers, the PDCA Architectural Specification Manual, Chapters 3 and $3 R$.

3.2.2.2 Obtain written approval for dry or liquid abrasive biasting from ICF KH. APPLICATION

3.3.1 Do not open containers until approved by ICF KH.

3.3.2 Mix materials in an ambient temperature above $45^{\circ} \mathrm{F}$ in a well ventilated and heated area, in accordance with the manufacturer's recommendations.

3.3.3 Perform work in accordance with manufacturers instructions, PDCA Architectural Specification Manual, and this Section.

3.3.4 Take precautions to prevent fire hazards and spontaneous combustion. Place cotton waste, cloths, and hazardous materials in containers and remove from the worksite daily.

3.4 FIELD QUALITY CONTROL

3.4.1 Inspection and testing will be performed by ICF KH.

3.4.2 Meet the requirements of PDCA Architectural Manual for "CUSTOM" material and work, unless otherwise specified.

3.5 SCHEDULES

3.5.1 Color: Unless otherwise noted, colors for incidental items not specifically scheduled will be selected by ICF KH.

3.5.2 Interior Paint and Finish: Exposed ferrous metal, light and ordinary exposers, Int 12-A, Custom Grade, semigloss. 


\section{METAL BUILDING SYSTEMS}

PART 1 - GENERAL

\subsection{REFERENCES}

1.1.1 The following documents, including others referenced therein, form part of this Section to the extent designated herein.

1.1.1.1 American Institute of Steel Construction, Inc (AISC)

ASD

Allowable Stress Design (Manual of Steel Construction)

1.1.1.2 American Iron and Steel Institute (AISI)

Design of Cold-Formed Steel

Structural Members

1.1.1.3 American Society of Civil Engineers (ASCE)

$7-88$

1.1.1.4 American Society for Testing and Materials (ASTM) Other Structures

Minimum Design Loads for Buildings and
A $446-91$

A 525-91b

C $665-91$

E $90-90$

E 283-84

E 331-86

E 413-87
Steel Sheet, Zinc-Coated (Galvanized) by the Hot-Dip Process, Structural (Physical) Quality

Steel Sheet, Zinc-Coated (Galvanized) by the Hot-Dip Process

Mineral-Fiber $\mathrm{B} 1$ anket Thermal Insulation for Light Frame Construction and Manufactured Housing

Test Method for Laboratory Measurement of Airborne Sound Transmission Loss of Building Partitions

Jest Method for Rate of Air Leakage Through Exterior Windows, Curtain Walls, and Doors

Test Method for Water Penetration of Exterior Windows, Curtain Walls, and Doors by Uniform Static Air Pressure Difference

Classification for Rating Sound Insulation 
1.1.1.5 American Weiding Society (AWS)
A2.4-93
Symbols for Welding, Brazing, and
D1.1-92
Nondestructive Examinations
Structural Welding Code-Steel

1.1.1.6 Builders Hardware Manufactures Association (BHMA)

A156.1-1988

Butts and Hinges

A156.2-1989

Bored and Preassembled Locks and Latches

A156.4-1986

Door Controls--Closers

A156.6-1986

Architectural Door Trim

A156. 18-1987

Materials and Finishes.

1.1.1.7 International Conference of Building officials (ICBO) UBC (1991 Edition) Uniform Building Code

1.1.1.8 Metal Building Manufacturers Association (MBMA)

Low Rise Building Systems

Manual (1986 Edition)

1.1.1.9 Society of Automotive Engineers (SAE)

AMS 5036G-85

Aerospace Material Specification; Steel Sheet and Strip, Aluminum Coated, Low Carbon

1.1.1.10 Underwriters Laboratories (UL)

Building Materials Directory (1993 Edition)

1.2 SUBMITTALS

1.2.1 See Section 01300 of $W-030-G 2$ for submittal procedures.

1.2.2 Approval Required

1.2.2.1 Erection instructions and diagrams: Before delivery, submit documentation necessary to erect building and instali components. Documentation shall include the following.
a. Anchor bolt layouts and sizes.
b. Structural connections.
c. Roofing and siding connections. 
d. Joint sealing and calking.

e. Door frame installation.

f. Wall penetration frame installation.

g. Flashings.

h. Accessory installation.

i. Details and instructions necessary for assembly.

j. Fabrication drawings necessary to supplement instructions and diagrams. Welding and examination symbols shall be in accordance with AWS A2.4.

k. Separate hardware list for each door.

1.2.2.2 Samples: Before delivery, submit color samples from the manufacturer's standard selection.

1.2.3 Approval Not Required

1.2.3.1 Certificate of compliance: With delivery, submit a certificate from manufacturer attesting that materials meet requirements of this Section and referenced documents.

1.3 SYSTEM DESCRIPTION

1.3.1 Metal Building: Single span structure, rigid frame, beam and column type.

1.3.1.1 Primary framing: Rigid frame of rafter beams and columns, braced end frames, end wall columns and wind bracing.

1.3.1.2 Secondary framing: Purlins, girts, eave struts, flange bracing, sill supports, clips and other items required for complete installation.

1.3.1.3 Wall and roof system: Preformed metal panels of vertical profile, insulation, liner sheets, and accessory components.

1.3.2 Design Criteria: Building and component design shall be in accordance with applicable sections of AISC ASD, AISI Design Specification, the MBMA Manua7, and the ICBO UBC.

1.3.2.1 Basic design shall include live, dead, snow, wind, and seismic loads. other design loads, either static or dynamic, shall be considered auxiliary loads.

1.3.2.2 Vertical live and snow loads:

a. Design roof covering for either a $50 \mathrm{lb} / \mathrm{ft}^{2}$ uniformly distributed load, or 200 pound concentrated live load over a 1 by 1 foot area located at the center of maximum roof panel span, whichever produces greater stress. 
b. Design primary framing and purlins for $20 \mathrm{lb} / \mathrm{ft}^{2}$ snow or live load Page 53 uniformly distributed over supported roof area.

1.3.2.3 Wind Toads: Design in accordance with ASCE 7-88, Section 6, using following criteria.
a. Basic wind speed: $70 \mathrm{mi} / \mathrm{h}$.
b. Importance factor: $I=1.07$ (for 100 year recurrence level).
c. Exposure category: $C$.

1.3.2.4 Seismic loads: Based on seismic accelerations of the ICBO UBC, Section 2312, for Seismic Zone 2B.

1.3.2.5 Auxiliary loads: Design roof framing for an auxiliary load of $10 \mathrm{lb} / \mathrm{ft}^{2}$ to accommodate loads imposed on the building from piping, lighting fixtures, heating units, and equipment, including the automatic fire sprinkler system.

1.3.2.6 Maximum deflection in roofing or roof panels shall not exceed 1/180th of spans, and maximum deflection in siding or wall panels shall not exceed 1/90th of spans.

1.3.2.7 Provide drainage to exterior for water entering or condensation occurring within cladding system.

1.3.2.8 Thermal resistance:
a. Wall system: $R$ value of 11 .
b. Roof system: $R$ value of 19 .

1.3.2.9 Weld steel in accordance with AWS D1.1.

1.4 DELIVERY, STORAGE, AND HANDLING

1.4.1 See Section 01610 of $W-030-G 2$ for generat requirements.

1.4.2 Damaged or defaced components may be repaired, if repairs are acceptable to ICF KH.

1.4.3 Store hardware items separately with fasteners and instructions, for individua? use.

$1.5 \quad$ WARRANTY

1.5.1 Buildings shall be warranted against water leaks, caused by normal atmospheric exposure, for a period of 5 years.

1.5.2 Warranty shall start upon final acceptance of Work, or the date the operating Contractor takes possession, whichever is earlier. 
PART 2 - PRODUCTS

\section{$2.1 \quad$ SUBSTITUTES}

2.1.1 See Scction 01630 of W-030-G2 for substitution approvals.

2.2 MANUFACTURED UNITS

2.2.1 Wal1, Roof, and Soffit Systems

2.2.1.1 Sheet steel stock: ASTM A 446, galvanized to ASTM A 525 G 90 . Factory color finished.

2.2.1.2 Wall system: 0.0217-inch (26-gage), exposed fastening panels.

2.2.1.3 Roof system: 0.0276-inch (24-gage), concealed fastening, standing seam configuration.

2.2.2 Insulation and Vapor Barriers

2.2.2.1 BTanket and batt insulation: ASTM C 665. Insulation containing asbestos is not acceptable. Insulation shall be listed in the UL Building Materials Directory, and have a "flame spread" of 25 maximum, and "smoke developed" of 50 maximum.

a. Wall insulation: Type II batts, with minimum thermal resistance of $\mathrm{R}-11$, faced with aluminum foil vapor barrier covering on one side. Insulation shall be capable of fitting into available space without compressing more than $10 \%$ in thickness.

b. Roof insulation: Type II batts, with minimum thermal resistance of R-19, faced with aTuminum foil vapor barrier covering on one side.

2.2.2.2 Vapor barrier for unfaced batt insulation: Polyethylene sheets, $4 \mathrm{mils}$ thick. Vapor barrier shall be listed in the UL Building Materials Directory, and have a "flame spread" of 25 maximum, and "smoke developed" of 50 maximum.

2.2.3 Wall Liner

2.2.3.1 Minimum thickness: 0.0217-inch (26-gage) flush panels, maximum 1 inch profile, zinc-coated (galvanized) to ASTM A 525, G90 with factory precoated finish.

2.2.3.2 Liner shall extend from floor to ceiling. Provide matching metal trim at base of wall liner, top of wall liner, around openings in walls and roof and over interior and exterior corners.

2.2.4 Sealant: Manufacturer's standard elastomeric, nonstaining type.

2.2.5 Fasteners: Manufacturer's standard type, finished to match adjacent surface when exterior exposed. 
2.2.6 Accessories: Flashing, trim, caps, and similar metal accessories shall Page 55 be of same thickness, material and finish used for adjacent wall or roof coverings.

2.2.7 Closure Strips: Formed of compressed rubber, synthetic rubber, bituminous impregnated materials, or metal of same respective type as roof and wall panels, and standard with manufacturer. Molded closure strips shall be free of open voids and shall not absorb or retain water. Closure strips shall be formed to match corrugations or configurations of roofing or siding being used and provided, where shown and necessary, for weathertight construction.

2.2.8 Doors, Frames, and hardware

2.2.8.1 Doors: Minimum thickness; $1-3 / 4$ inches thick, constructed of 0.0396 -inch (20-gage) hot dipped galvanized steel, economy type, meeting STC 34 as tested according to ASTM E 90 and E 413. Air infiltration shall meet ASTM E 283. Water infiltration shal1 meet ASTM E 331 .

2.2.8.2 Door leaf: Futl flush (plain).

2.2.8.3 Door frame: 0.0516-inch (18-gage) galvanized steel. Door frame shall consist of door posts, door jamb, door header, header reinforcement, sill plate, clips and extensions as required. Door frame shall be knock down type with upper ends of members butted to provide square and solid joints for threaded fastener attachments.

2.2.8.4 Door jambs: 5-3/4 inches deep with unequal rabbets (1-15/16 inch, $1-9 / 16$ inch). Face width shall be 2 inches with double return. Jambs shall be retained at floor line by a sill plate with slips welded at each end. Jambs shall have brackets welded at fixed locations for attachment of door posts.

2.2.8.5 Door and frame finish: Manufacturer's standard.

2.2.8.6 Threshold and weatherstripping: Threshold sha1l be BHMA A156.6 aluminum extrusion with mill finish drilled and countersunk for attachment to floor and shall have notched ends to fit the door jamb rabbets; Pemko. Weatherstripping shall be a concealed door sweep of EPDM materia?. Perimeter weatherstripping shall be an adhesive backed press-on flexible black TPE material, factory installed on the frame, astragal or mullion.

2.2.8.7 Door hardware: Closer shall conform to BHMA A156.4, Type C02063; Corbin or an approved substitute. Closer reinforcement sha11 be 0.1084 -inch (12-gage) galvanized steel, field installed in door header. Hinges shal1 be BHMA A156.1, two $1-1 / 2$ pair of $4-1 / 2$ by $4-1 / 2$ inch steel hinges, full mortise 0.134 -inch thick, plain bearing action, with nonremovable button-tip pin; Stanley or an approved substitute. Hinges shall be primed and painted in accordance with the manufacturer's standard.

2.2.8.8 Lock set: BHMA A156.2, Series 1000, Grade 1. Lock set function shal1 be latch bolt retracted by key in the outside knob only. Corbin or an approved substitute. 
2.2.8.9 Lock cylinders: Furnish 5-pin tumbler cylinders with Corbin 67 keyway and 2 keys for each lock set. Key locks to match existing master-key system as directed by ICF KH.

2.2.8.10 Fasteners: Furnish necessary screws, bolts, or other fasteners of suitable size and type to anchor hardware in position. Match hardware finish. Furnish with expansion shields, toggle bolts, or other appropriate anchors.

2.2.8.11 Hardware finish: BHMA AI56.18, 260 du11 chrome finish, unless otherwise noted.

2.2.9 Ventilator (Louver): End wall, ventilator/louver openings to be provided complete with framing and weather flashing in preparation for the installation of the end wall ventilators by others. Construction of the framed openings shall be in accordance with the manufacturer's standard details. The location of openings and all other requirements shall be in accordance with the Project drawings.

2.2.10 Nonshrink Grout: See Section 03300 .

2.2.11 Finish: Precoated enamel on steel with color selected from manufacturer's standards by ICF KH. Provide one quart of each color used to the operating contractor along with recommended application instructions.

PART 3 - EXECUTION

\subsection{INSTALLATION}

3.1.1 Erect in accordance with manufacturer's approved erection instructions and diagrams.

3.1.2 Set structural elements on nonshrink grout.

3.1.3 Insulate dissimilar materials, not compatible when in contact, from each other by gaskets or insulating compounds.

3.1.4 Wall and Roof Systems

3.1.4.1 Exercise care when cutting prefinished material to ensure cuttings do not remain on finish surface.

3.1.4.2 Fasten cladding system to structural supports, al igned level and plumb.

3.1.4.3 Use concealed fasteners for roof system and exposed fasteners for wail system.

3.1.4.4 Apply sealant or gasket materials to prevent weather penetration.

3.1.4.5 Installed systems shall be free of rattles, noise due to thermal movement, and wind whistles.

3.1.5 Attach louvers and ventilators to supporting construction to assure rain-tight installation. 
3.1.6 Anchor doors and windows, including frames and hardware, to supporting Page 57 construction, install plumb and true, and adjust to provide proper operation.

3.1.7 Insulation: Except as ornerwise shown on the Drawings or approved, install insulation against covering and between supporting members to present neat appearance. Lap and fasten blanket insulation facing to provide tight joints.

3.1.8 Fasten wall liner into place to present neat appearance.

\subsubsection{Field Painting}

3.1.9.1 Upon detection, wire brush and touch-up abraded or corroded spots on shop-painted surfaces with the same material used for the shop coat.

3.1.9.2 Paint exposed, shop primed ferrous surfaces on building exterior, and shop primed door and window surfaces with 2 coats of approved exterior ename?.

3.1.9.3 Touch-up factory color finished surfaces, with manufacturer's recommended touch-up paint, as necessary.

END OF SECTION 


\section{CHEMICAL PROCESS PIPING SYSTEMS}

PART 1 - GENERAL

\subsection{REFERENCES}

1.1.1 The following documents, including others referenced therein, form part of this Section to the extent designated herein.

1.1.1.1 American National Standards Institute (ANSI)

A13.1-1981 (R 1985)

Scheme for the Identification of Piping Systems

\subsubsection{American Society of Mechanical Engineers (ASME)}

B16.3-1992

B16.5-1988

B16.9-1993

B31.3-1993

NQA - 1-1989 1994
Malleable Iron Threaded Fittings, Classes 150 and 300

Pipe Flanges and Flanged Fittings

Factory-Made Wrought Steel Buttwelding Fittings

Chemical Plant and Petroleum Refinery Piping

Quality Assurance Program Requirements for Nuclear Facilities Facility Applications

1.1.1.3 American Society for Nondestructive Testing (ASNT)

SNT-TC-1A

Recommended Practice (December 1988 Edition)

1.1.1.4 American Society for Testing and Materials (ASTM)
A $47-90$
Malleable Iron Castings

A $53-90 b$

Pipe, Stee1, Black and Hot- Dipped, Zinc-Coated Welded and Seamiess

A 105-92

Forgings, Carbon Steel, for Piping Components

A $106-91$

Seamless Carbon Steel Pipe for High-Temperature Service

A $197-87$ (1992)

Cupola Malleable Iron 

A 234-92a

A $307-92 a$

A 312-92a

A $403-91$

A. $563-92 \mathrm{a}$

B $62-93$
Piping Fittings of Wrought Carbon Stee]Page 59 and Alloy Steel for Moderate and Elevated Temperatures

Carbon Steel Bolts and Studs, 60000 psi Tensile Strength

Seamiess and Welded Austenitic Stainless Steel Pipes

Wrought Austenitic Stainless Steel

Piping Fittings

Carbon Alloy Steel Nuts

Composition Bronze or Ounce Metal Castings

1.1.1.5 American Waterworks Association (AWWA)

C213-91

1.1.1.6 . Instrument Society of America (ISA)
Fusion Bonded Epoxy Coating for the Interior and Exterior of Steel Water Pipelines

$$
\text { S20-1981 }
$$

Specification Forms for Process Measurement and Control Instruments, Primary Elements and Control Valves

1.1.1.7. Manufacturers Standardization Society of the Valve and Fittings Industry (MSS)

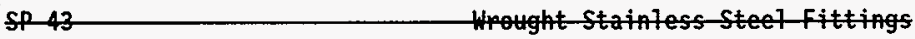

SP-58, 1988

SP-69, 1991

SP-89
Pipe Hangers and Supports - Materials, Design and Manufacture

Pipe Hangers and Supports - Selection and Application

Pipe Hangers and Supports - Fabrication and Installation Practices

1.1.1.8 Steel Structures Painting Council (SSPC)
SP 3-82
Power Tool Cleaning
SP 6-85
Commercial Blast Cleaning

1.1.1.9 American National Standards Institute (ANSI)

A13. 1-1993

Identification of Piping Systems

$\mathrm{ECN}-85$ 
1.1.1.10 Federal Standard (Fed. Std.) FED-STD-595

\subsubsection{Federal Specification (FS)}

$$
T T-E-489
$$

HNF-2532, Rev. 0

Pg. 60 ecte-85

Colors Used in Government Procurement

Ename7, A7kyd, Gloss, Low VOC Content ECN-85 
1.2.1 See Section 01300 of $W-030-G 2$ for submittal procedures.

1.2.2 Approval Required

1.2.2.1 Approval data: Before delivery, submit information listed in the Approval Data List in this Section.

1.2.2.2 Certified material test reports (CMTRs): Before delivery, submit legible reports, certified by responsible manufacturer of materials used in the fabrication of pipe, fittings, flanges, boiting and weid rods for pipe codes below. Report shall present results of chemical analysis and physical test specified by ASME and ASTM codes and standard specifications for production lots and heats of materials. Submit separate reports for the following:

a. Pipe Code M-9; Service, Supernate (SN) and Slurry (SL) lines

b. Pipe Code M-26a; Service, Supernate (SN) and Slurry (SL) I ine encasements

Material traceability to be maintained through fabrication for materials requiring CMTRs.

ECN-145

ECN-145

\subsubsection{Approval not required}

1.2.3.1 Vendor information: Before installation, submit information listed in the Vendor Information. List in this Section.

\subsection{QUALITY ASSURANCE}

1.3.1 Contractor's Quality Assurance Program: See Section 01400 of W-030-G2. (EXCEPTION: For paragraph 1.7 [Schedule of Hold and Witness Points] only 15493-3 [Leak/Pressure Testing] applies.)

1.3.2 Misrepresented Products: See Section 01400 of W-030-G2 for required measures to prevent the use of misrepresented products.

1.3.3 Safety related products: Safety-ass $z$ Safety Significant products shall be procured from qualified suppliers. These suppliers shall have a quality assurance program meeting the ASME. NQA-1 Basic Requirements 1, $2,4,6,7,8,11$ through 15 and 17 .

1.3.4 Welding Qualification

1.3.4.1 Qualification of We]ding Personnel and Procedures: Personnel and procedures for welding pressure retaining components along with attachments thereto, and pipe supports, shall have been qual ified in accordance with ASME B31.3, Paragraph 328.2 (A 328.2) before weiding. 
1.3.4.2. Qualification of Nondestructive Examination (NDE) Personnel:

1.3.4.2 Qualification of Nondestructive Examination (NDE) Personnel:

Page 62

a. Visual weld examinations shalt be performed in accordance

with ASME B31.3. Welding Inspectors (EWI) who have peecived centificition in aceordance with AWS QC1. Certified Associate-Welding-Inspectors (CAWI), certified in aceordance-with- the above-standard, may perform-examinations when theler im diate direction-of CHIS-

b. Welding related examination documentation-shall be-signed, or stamped by individual performing examination. Where-CAlls perform examinations, documentation-shall be-signed-or-stafled by both-CAWI and CWI under-whem-examinations-were-pexformed.

eb. Personnel performing other NDE shall be certified in accordance with Contractor's written practice, which shall meet the requirements of ASAF SNT-TC-IA. USe Level III to interpret test results.

1.3.4.3 Extent-of Application: The above qualification requirements-atso-apply for preliminary fabpication of papts, from matepials specified in 2.2, when fabrication is accomplished in shops other than the material stppliers-shops, but not neessarily, at the-worksite.

1.3.5 Deliverable Documentation: The following documents and records,
required by this Section, shall be delivered to ICF KH in accordance with Section 01720 of W-030-G2.

Document

FTushing/Mechanical Cleaning Verification

Welding Examination Documentation

Leak/Pressure Test Certification
Paragraph

3.2 .2 .5

3.2 .1

$3.2 .3 .1 \mathrm{~b}$

1.4 DELIVERY, STORAGE, AND HANDLING

1.4.1 See Section 01610 of W-030-G2 for general requirements.

PART 2 - PRODUCTS

2.1

2.1 .1

2.2

2.2 .1

2.2 .1 .1

\section{SUBSTITUTES}

See Section 01630 of W-030-G2 for substitution approvals. MATERIALS

Piping and Fittings: See the Pipe Codes in this Section and details on the Drawings.

When approved by the Construction Engineer, integrally reinforced branch connections may be used on 2-inch and larger welded main lines instead of buttwelding tees noted in pipe codes. Material and weight shall correspond to pipe code for particular piping system. 
2.2.1.2 Close or butt nipples are not permitted, unless shown on the Drawings.

Pipe Joint Sealant (Lubricant) for Threaded Joints: For design temperatures up to $500^{\circ} \mathrm{F}$, use nonhardening teflon paste: Chesterton "Goldend" No. 7298, Federal Process Company "JC-30", or Lake Chemical Company. "Siic-Tite."

2.2.3 Protective coating for piping in contact with earth or concrete.

2.2.3.1 Carbon steel piping: Factory and field applied exterior protective coating; AWWA C213, fusion bonded epoxy coating of 14 mils minimum thickness, Scotchkote $206 \mathrm{~N}$ or an approved substitute.

2.2 .4

Paint: See Section 09900, with piping identification as specified in Appendix A.

2.2.5 Nonshrink grout: See Section 03300 .

2.2.6 Pipe supports: Pipe supports shall be as shown on the drawings with standard components selected in accordance with MSS SP-69, that satisfy the criteria of MSS SP-58.

\subsection{EQUIPMENT}

2.3.1 Valves, duplex strainer and back flow preventer: Specified in Pipe Codes, unless shown otherwise on the Drawings.

2.3.2 Flow meter: See the Data Sheet Y-0101.

\section{PART 3 - EXECUTION}

\section{$3.1 \quad$ INSTALL.ATION}

3.1.1 General

3.1.1.1 Fabricate and instal1 pipe in accordance with ASME B31.3 (for normal service), Drawings, and this Section.

3.1.1.2 Cut pipe using methods which result in clean, straight cuts.

3.1.1.3 Ream pipe to nominal inside diameter after cutting. Remove burrs from threads before assembly.

3.1.1.4 Tools marked for stainless steel shall be used on stainless steel only.

3.1.1.5 Bend pipe in accordance with ASME B31.3, and meet tolerances given in ASME B31.3. Use methods and equipment which produce bends free of wrinkles, bulges, or kinks. When wall thickness, diameter, and bend radius indicate possibility of wall collapse during bending, fill pipe with clean silica sand or fusible material similar to Cerro-bend, manufactured by Cerro Corporation. 
a. Application of heat to facilitate a pipe bend shall be brought Page 64 to the attention of the Responsible Engineer for disposition and direction.

b. Cold springing pipe permitted only if specified on the Drawings.

3.1 .1 .6

3.1 .1 .7

3.1 .1 .8

3.1 .1 .8 .1

3.1 .1 .9

bolts.

3.1.1.10

3.1 .1 .11

3.1 .2

3.1.2.1

3.1 .2 .2

3.1.2.3

3.1 .3

3.1.3.1

3.1.3.2
Make joints in threaded piping systems with joint sealant specified. Apply sealant to male threads: only.

Carbon steel embedded in concrete shall be bare.

Piping systems shall be kept clean. Piping systems shall be inspected and checked to be free of debris and foreign materials before, during and after installation.

Once fabrication has started, plug or cap ends of piping when installation is not in progress to prevent entry of dirt and other foreign material. Cap or plug openings in fabricated pipe spool assemblies until installation in piping system. Leave ends of spare lines capped or blind flanged when installation has been completed.

High point vents shall not be provided on $S N$ and $S L$ lines. Provide $E C N-85$ drain taps at low points to ensure complete drainage and drying in piping systems using water for cleaning and leak/pressure testing. Venting may be provided by loosening flanges having minimum of 4

Pipe supports: Install as shown on the Drawings, in accordance with manufacturer's instructions, and applicable recommended procedures of MSS SP-89.

Direction shall be obtained from the Operating Contractor for disposal of waste flushing and testing water.

Underground piping

Trenches: Excavate, backfill, and compact in accordance with Section 02225 .

Place piping supports on undisturbed soil or backfill placed and compacted in accordance with Sections 02200 and 02225 .

Survey piping systems for elevation and location. Complete placement of supports and meet specification and drawing requirements before survey. Elevation and location shall be in accordance with the Drawings. Piping system shall be surveyed for final acceptance.

Weiding

Weld piping, attachments to pressure retaining components, and pipe supports in accordance with ASME B31.3 and Project Drawings.

Protect outdoor welding operation from rain and wind by using barriers to protect weider and weld joint. 
Complete piping welds before tie-in welds to pits, or fixed items. Page 65

3.1.3.4 Remove backing strips if used.

3.1.3.5 Gas Tungsten Arc Welding (GTAW) process shall be used for root pass welds of carbon steel encasement pipes where stainless steel inner pipes cannot be protected from weid splatter.

Weld Identification

3.1 .4 .1

Prepare weld maps using Project Drawings or Sketches identification Arawings, isometric op-spoot, which show relative position of each pressure containing weld and each attachment weld to pressure retaining components.

3.1 .4 .2

Assign and record weld-number to-ach presture-containing-weld and each atta ment-weld to pressure-retaining-components-as-made. Record weld number on weld maps atentification as weld is made.

3.1.4.3 Place the welder identification symbol and weld number adjacent to each weld upon completion. Place the identification symbol

approximately every 3 feet on long seams or large weldments, using one of the marking methods specified in Section 01610.

3.1.4.4 Do not reuse weld numbers. If weld is completely replaced, assign new number.

3.1.4.5 Show heat/lot numbers on weld maps identification-drawing for materials requiring Certified Material Test Reports.

3.1 .5

Perform NDE, flushing, leak/pressure testing specified in 3.2 , before coating application.

3.1 .6

Exterior Protective Coating

3.1 .6 .1

Piping in the water service building shall be painted as specified in Section 09900 and identified as specified in Appendix A.

Protect carbon steel pipe and fittings exposed to earth backfill with specified coating. See Section 02650 for underground raw water ECN-133 service exterior protective coating.

a. Clean carbon steel surfaces to white metal by sandblasting in accordance with SSPC SP 6 . Where blasting is impracticable, clean by power wire brushing in accordance with SSPC SP 3.

b. Apply specified coating in accordance with AWWA C213 and manufacturer's instructions.

3.1.6.3 After installation, examine carbon steel pipe having factory applied exterior protective coating, and joints, fittings, and short lengths of pipe having field applied exterior protective coating materials.

a. Use electrical holiday detector in accordance with AWWA C213. 
b. Repair damage to coating in accordance with AWWA C213. carried and direction of flow as specified in Appendix A. 
$3 . \hat{2} \quad$ FIELD QUALITY CONTROL

3.2.1 Nondestructive Examination (NDE) of Wels welds shall be performed to the extent defined in ASME: B31.3, Paragraph 341.4.

$\mathrm{ECN}-85$

$\mathrm{ECN}-85$

3.2.1.1 Perform NDE for each pipe code listed in the schedule in 3.3.

3.2.1.2 Visual examination: Perform in accordance with ASME B31.3,

Paragraph 344.2. Acceptance criteria shall be per ASNE B31.3, ECN-85

Table 341.3.2A.

ECN-85

3.2 .1 .3

tiquid-penetrant (dye-penetrant) examination-(PT) -process examination in accordance with ASME B31.3, Paragraph 344.4 344.7 .

ECN-85

3.2.1.4 Radiographic examination (RT): Perform in accordance with

ASME B31.3, Paragraph 344.5. Acceptance criteria sha7l be per. ASME B31.3, Table 341.3.2A.

a. Identify radiographic film with weld identification number and project or work order number assigned to work covered by this

Section.

b. Prepare radiographic examination reports as follows:

1) List each radiographic exposure location $(0-1,1-2, \ldots)$ individually on radiographic examination report.

2) Indicate location acceptability or rejectability and note discontinuities whether rejectable or not.

3) When report includes radiographs of welds which have been repaired, indicate which welds are repair welds and how many times each weld has been repaired.

c. If additional welding is performed on weld area which has aiready been examined radiographically, this. area is repair area. Identify subsequent radiographs by "R-1, $R-2$ ", etc.

3.2.1.5 Perform visual examination of piping supports welds safety-Class 3 -systems in accordance with ASME B31.3, Paragraph 344.2.

3.2.1.6-____-Perform-100-pereent-vistal examination of piping supports fop-Safety C7ass-2 systems-in-aceopdance-with-ASHE-B31.3, Paragraph-344.2.

$\mathrm{ECN}-85$

ECN-85

3.2.1.76 NDE documentation:

ECN-85

a. Document examination of pressure containment welds and welds to pressure containing components for piping systems on NDE/Weld Record Form KEH-0433. See Form KEH-0433 for instructions for recording weld 
HNF-2532, Rev. 0

identification drawings, weld numbers, welder identification, weldingPage 68 procedure numbers, weld filler material, visual examinations, nondestructive examinations, and for noting satisfactory completion of leak/pressure testing. 
b. Required NDE shall be completed and documented before start of Page 69 leak/pressure testing.

c. NDE/Weld record information and weid maps

diansisas specified in 3.1.4 may be incorporated on a single format or traveler for a specific work package.

d. Document examination of pipe supports by recording on sketches or NDE/Weld Record form.

3.2 .2

3.2 .2 .1

3.2 .2 .2

3.2 .2 .3

\section{Cleaning and Flushing}

After NDE is complete and before leak/pressure testing system, or before connecting system into existing system, clean piping internal surfaces mechanically or by. flushing.

Mechanical cleaning: Remove loose dirt, scale, and debris by brushing, wiping, high pressure water jetting, or other mechanical method approved by Construction Engineer.

a. When high pressure water jetting or other mechanical cieaning method utilizing water is used, and leak/pressure testing will not be performed immediately after cleaning, dry piping systems by blowing dry oil-free air or nitrogen through Tines.

b. Dry until the relative humidity of discharge air is equal to that of inlet air. Use drain taps at low points of piping system to ensure complete drainage and drying. Cap lines or reconnect to system to maintain cleanliness.

Water flushing:

a. Remove strainer screens before flushing, except those protecting control equipment. Clean screens protecting control equipment before flushing, if necessary, and after flushing is complete.

b. Flush piping with water for 1 minute minimum, and until effluent is clean and contains no visible particulate matter. Flushing pressure shall not exceed maximum operating pressure specified in pipe codes. Flushing water supply shall have sufficient capacity to produce a flow velocity of 4 to $6 \mathrm{ft} / \mathrm{s}$ in largest pipe size, with pipe full. Provide flow measurement in flushing water supply line to be used as basis for verification of flow velocities in piping system by Construction Engineer.

c. When leak/pressure testing will not be performed immediately after flushing, dry tabulated piping systems by blowing dry, oil-free air or nitrogen through lines. Dry until the relative humidity of discharge air is equal to that of inlet air. Use drain taps at low points of piping systems to ensure complete drainage and drying. Cap lines or reconnect to the systems. 
Pneumatic flushing for instrument air (IA) and encasements (ENCs) piping only:

a. Isolate instruments by valving, plugging or disconnecting.

b. Blow lines clean with dry, oil-free air or nitrogen at 20 to $301 \mathrm{~b} /$ in $^{2}$ gage, until discharge air has no visible particulate matter or for 5 minutes minimum. If pipe code maximum operating pressure are lower, use those pressures.

c. If leak/pressure testing is not performed immediately after flushing, cap lines or reconnect to system to maintain cleanliness.

Provide documented evidence that flushing or mechanical cleaning has been performed as specified in this Section.

Leak/Pressure Testing

General :

a. After completion of flushing, perform leak/pressure testing of pipe in accordance with ASME B31.3 and this Section. Use calibrated gages with ranges $1-1 / 2$ to $z 4$ times the test pressure.

b. Document testing of each piping system on "Leak/Pressure Test Certification" Form KEH-1757. Use separate forms to describe and record each piping system. Under "Description" describe piping system in enough detail for correlation to weld identification drawings, shop fabrication drawings, or Project Drawings as applicable. For systems tested segmentally, indicate continuity in "Description" to assure that entire systems have been tested.

c. Pipe joints, fittings, and other potential leak sources to be tested shall be visible and accessible during tests.

d. Install one temporary relief valve during testing. Relief valve shall have a discharge capacity of $125 \%$ of capacity of the pressurizing device, and be set to operate at $1-1 / 3$ maximum of the test pressure for hydrostatic testing and not higher than test pressure plus the lesser of $50 \mathrm{lb} / \mathrm{in}^{2}$ or $10 \%$ of the test pressure for pneumatic testing. Tag each relief valve used to show serial number, inspector, date, and pressure setting.

e. Install necessary restraining devices, before applying test pressure, to prevent distortion or displacement of piping.

$f$. Isolate instruments and other items which could be damaged by test pressures.

g. Continuously maintain test pressure for 10 minutes minimum. Examine joints and connections. Piping system shall show no visual evidence of weeping or leaking. 
h. Visually examine piping joints, fittings, and other potential Page 71 leak sources, including welds which attach wear plates, anchors, etc to piping systems, during testing.

i. Complete testing of piping before field application of protective coating. Pipe with factory applied protective coating shall be considered as having been tested before protective coating application.

3.2.3.2 - Hydrostatic pressure testing:

a. Perform in accordance with ASME B31.3, Paragraph 345.4,

b. Purge air from piping systems during filling, before applying pressure.

c. Coat welded piping joints, fittings, and other potential leak sources, including welds attaching wear plates, anchors, etc, to piping systems, with a mixture of powdered blue chalk and water or isopropyl alcohol. Allow to dry before filling piping with water and inspecting for leaks.

d. Remove water from piping systems after testing and dry by blowing dry, oil-free air or nitrogen through lines. Dry until the relative humidity of discharge air is equal to that of inlet air. Use drain taps at low points of piping systems to ensure complete drainage and drying.

Pneumatic pressure testing: (for instrument air [IA] and encasement [ENC] lines only).

a. Perform in accordance with ASHE B31.3, Paragraph 345.5 .

b. Perform testing with dry, oil-free air or nitrogen on piping systems. 


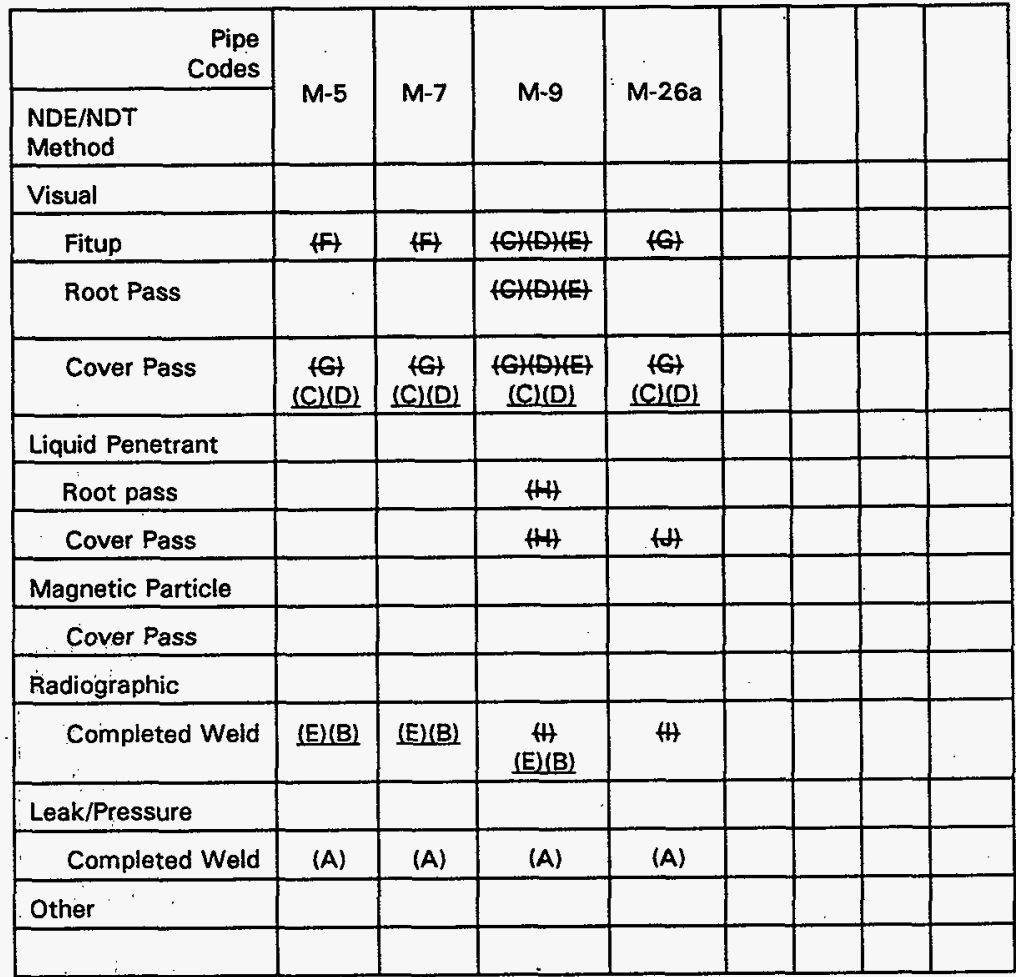

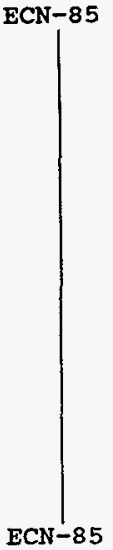


Legend: A. Requires witnessing and acceptance by ICF KH Title III

HNF-2532, Rev, 0

Page 73 Acceptance Inspection prior to recording.

B. Requires acceptance of radiographs and documentation by $\mathrm{KEH}$ Title III Acceptance Inspection prior to recording.

G. Gireumforentiatandongitudinal buttwolds.

Q. Full penotration-wolds an-branomentions.

E.-Atotopipo-

FC. Random visual examination for $5 \%$ of all tengitudinat and circumferential welds, full penetration welds on branch connections and attachment welds to pipe.

GD. $100 \%$ visual examination of longitudinal welds.

H. Liquid penetrant oxamino-allwolds that aro not radiographed.

1E. Random radiography for $5 \%$ of primary alt circumferential butt: welds. In-process examination may be performed in lieu of radiography.

L. Random liquid ponetrant for $10 \%$ of wolds not roliegraphed. 
HNF-2532, Rev. 0

Page 74

ECN-805

ECN-133

$\mathrm{ECN}-133$

$\mathrm{ECN}-133$

(1) Fop inacessible op underground fines use wought-steel buttwelding in aceordance-with-ASHE-B16.9, material in aceordance with ASTM A 234, Grade-WPB, wa77 thickness to match-pipe-

Class 150 malleable iron, ASTM A 47, Grade 32510 or 35018 or ASTM A 197 threaded in accordance with ASME B16.3, bronze to iron seat. (No buried unions.)

Class 150 forged steeT, ASTM A 105, raised face, weld neck, in accordance with ASME B16.5. Bore to match pipe ID. Use flanges for pipe sizes $8^{\text {" }}$ and larger. Use flat face where mating to flat face flanges.

Bolting Alloy steel studs, ASTM A 307, Grade B, and heavy hex nuts, ASTM A 563, Grade A.

Gaskets Compressed fiber, nonasbestos, 1/16" thick sheet; Garlock "Blue-Gard" Style 3100. Use full face gaskets with flat face flanges.

Black steel, ASTM A 53, Type E, Grade B or

Schedute 40, minimum

ECN -133

1

ECN -133 


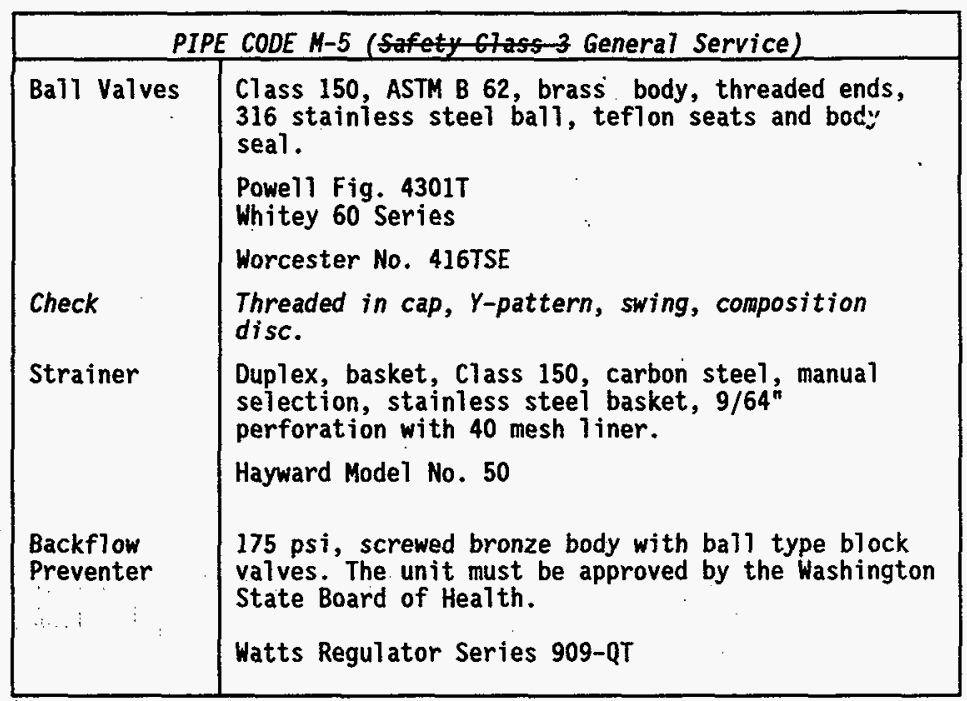




\begin{tabular}{|c|c|}
\hline \multicolumn{2}{|r|}{ PIPE CODE M-7 (Safety-Class-3 General Service) } \\
\hline server & 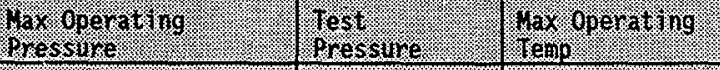 \\
\hline 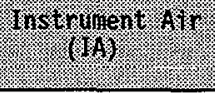 & 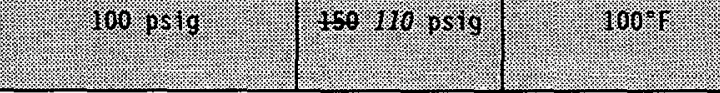 \\
\hline Sizes & $1-1 / 2^{\prime \prime}$ and smaller \\
\hline Pipe & $\begin{array}{l}\text { Carbon stee1, ASTM A } 53 \text {, Type E, Grade B or } \\
\text { ASTM A } 106 \text {, Grade B. }\end{array}$ \\
\hline Wal1 Thickness & Schedule 40 \\
\hline Nipples & Schedule 40 , close or butt not permitted. \\
\hline Fittings (1) & $\begin{array}{l}\text { Class } 150 \text { malleable iron, ASTM A } 47 \text {, Grade } 32510 \text { or } \\
35018 \text { or ASTM A } 197 \text { threaded in accordance with ASME } \\
\text { B16.3. }\end{array}$ \\
\hline Unions & $\begin{array}{l}\text { Class } 150 \text { malleable iron, ASTM A } 47 \text {, Grade } 32510 \text { or } \\
35018 \text { or ASTM A } 197 \text { threaded in accordance with ASME } \\
\text { B16.3, bronze to iron seat. (No buried unions.) }\end{array}$ \\
\hline $\begin{array}{l}\text { (1) For inacc } \\
\text { buttwelding in } \\
\text { accordanc } \\
\text { 234, Grade WPB }\end{array}$ & $\begin{array}{l}\text { sible or underground lines use wrought steel } \\
\text { with ASME B16.9, material in accordance with ASTM A } \\
\text { wall thickness to match pipe. }\end{array}$ \\
\hline
\end{tabular}


I ^әу 7 L!ng-s

โว-0ZE-M

980-NOE

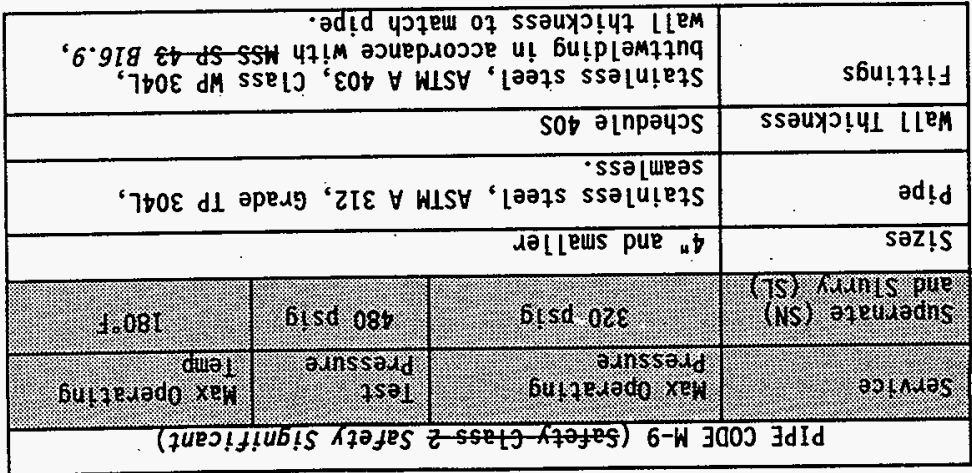




\begin{tabular}{|l|l|l|l|}
\hline \multicolumn{3}{|c|}{ PIPE CODE M-26a (Safety Class 3 General Service) } \\
\hline Service & $\begin{array}{l}\text { Nax. } \\
\text { Operating } \\
\text { Pressure }\end{array}$ & $\begin{array}{l}\text { Test } \\
\text { Pressure }\end{array}$ & $\begin{array}{l}\text { Max. Operating } \\
\text { Temperature }\end{array}$ \\
\hline $\begin{array}{l}\text { Supernate line } \\
\text { Encasement (ENC) and } \\
\text { Slurry Line } \\
\text { Encasement (ENC) }\end{array}$ & 320 Psig & $\begin{array}{l}480352 \\
\text { Psig }\end{array}$ & $180^{\circ} \mathrm{F}$ \\
\hline Size & All & \multicolumn{1}{|c|}{} \\
\hline Pipe & Carbon steel, ASTM A 106, Grade B \\
\hline Wall Thickness & \begin{tabular}{l} 
Schedule 40 \\
\hline Fittings
\end{tabular} & $\begin{array}{l}\text { Wrought carbon steel, ASTM A 234, Grade WPB, } \\
\text { butt welding in accordance with ANSI B16.9 } \\
\text { (schedule to match pipe). }\end{array}$ \\
\hline
\end{tabular}

ECN-805

ECN-127 


\section{FURBIAE FLOWHETEAS}

(Based-on ISA S20.24)

HEFER

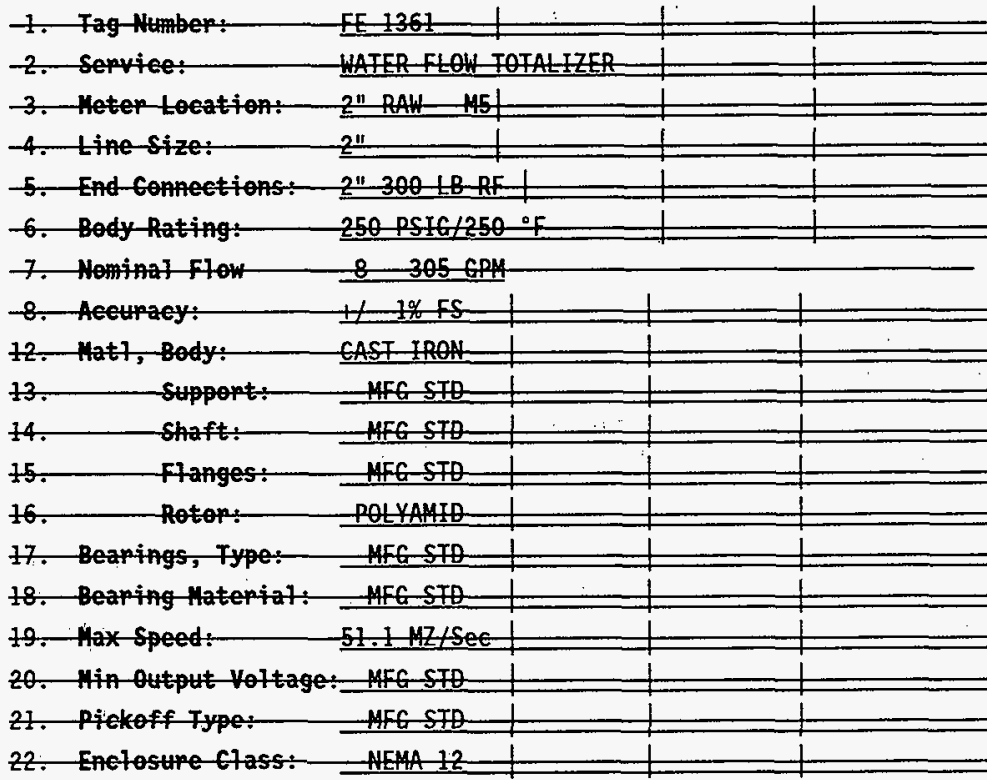

fHUIO DATA

24.-Fruid:

25.-Min/Hax-Flow Rate: \& to 305 CPHI

26. Noma7 Flow:

27:- Opep-Presstrpe: 160-Psio

29. Hin/Hax-Opep Temp:-40 100 of

30. Operating-Sp-6m-1.0 at-60\% 
HNF-2532, Rev. 0

Y-0101

Sheet 1 of 2 ECN-413

POSITIVE DISPLACEMENT METERS

(Based on ISA \$20.25)

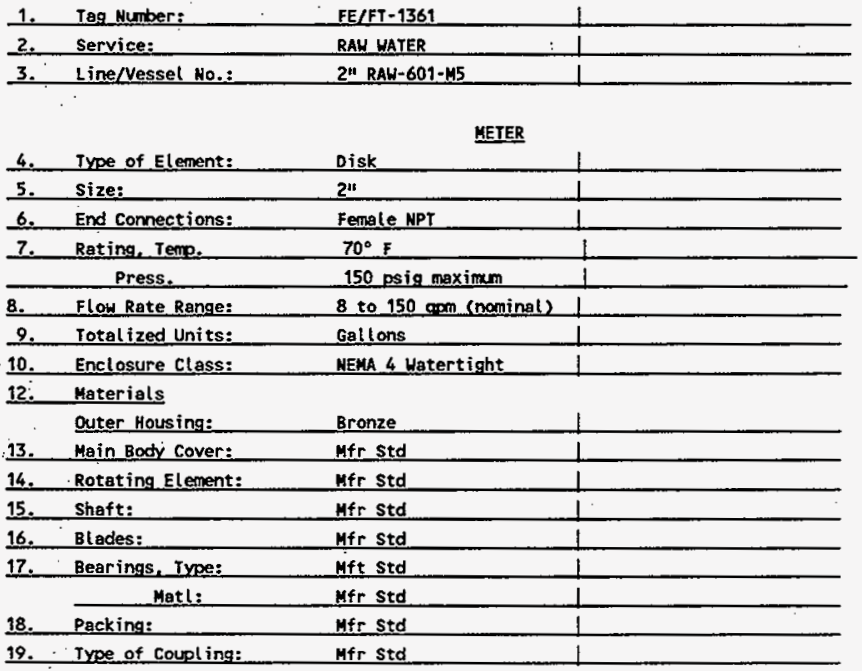

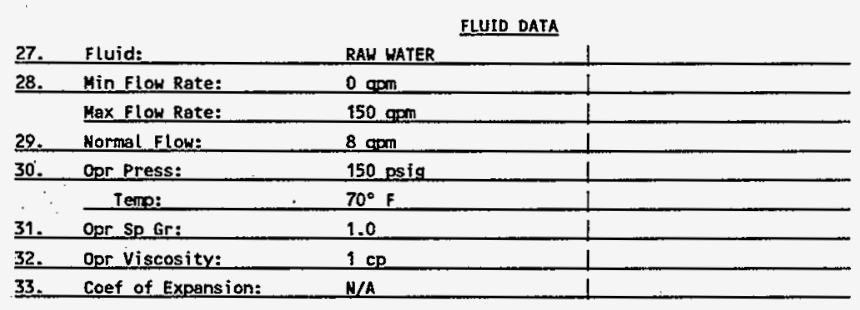

\begin{tabular}{|c|c|c|}
\hline \multirow[b]{2}{*}{34.} & \multirow[b]{2}{*}{ Flow Units: } & OPTIONS \\
\hline & & Gallons \\
\hline 38. & Transmitter Type: & Frequency converter \\
\hline \multirow[t]{2}{*}{39.} & Iranemitter & \\
\hline & output: & 4-20 mA de \& pulse output (open col lector transistor) \\
\hline 42. & Enclosure: & WEMA 4 Watertight \\
\hline
\end{tabular}


HNF-2532, Rev. 0

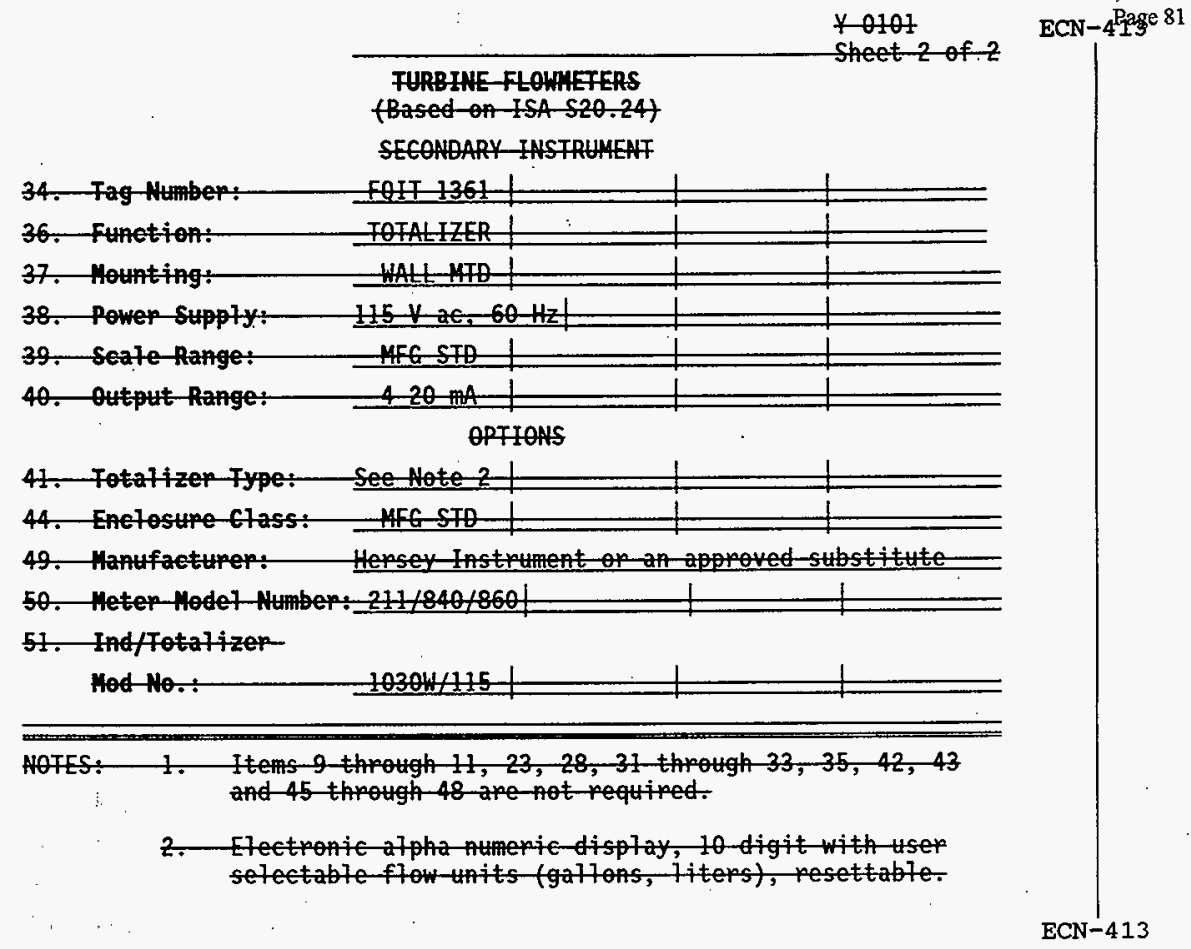


POSITIVE DISPLACENEKT -METERS

(Based on ISA S20.25)

43. Molessing:

Integral with meter

44. Electrical conn: 1/2" NPT

45. Manufacturer:

Badger Meter Inc/Industrial |

46. Model Number: M-120 W/PFT420

1

NOTES:

1.

Items $3,11,20$ through 26,35 through 37,40 and 41 are not required. 2. Accuracy: $\pm 2 x$ of full scale.

HNF-2532, Rev. 0

$Y-0101$ ECN-4 Page 82

Sheet 2 of 2 
NDE/WELD RECORD

(KEH-0433.00)

HNF-2532, Rev. 0

Page 85 
NONDESTRUCTIVE EXAMINATION/TESTING REQUIREMENTS FOR PIPING SYSTEMS

HNF-2532, Rev. 0

(KEH-0433.00R)

Page 86 
END OF SECTION 


\section{GENERAL}

The identification of piping systems shall be in accordance with the American Standard Scheme for the Identification of Piping Systems, ANSI A13.1, as supplemented herein.

\section{LOCATION}

a. Except as provided below, identification shall be located adjacent to outlets, valves, flanges, unions, changes-in-direction, where pipes pass through walls, floors, or ceilings, and along an uninterrupted length of pipe at maximum intervals of 50 feet. Each 1 ine or branch in a room shall have at least one identification.

b. Where a number of outlets, valves, flanges, unions, or changes of direction make identification at each item impracticable, they may be spaced at approximate 6 foot intervals, preferably adjacent to valves.

c. Legend shall be located on the pipe so that it can be read easily from the operator's normal viewing position. Labels shall be placed on the readily visible lower quadrant of overhead pipes, and on an upper quadrant of pipes below normal eye level. Above ceilings, labels shall be placed in locations most readily visible from access positions.

3. LEGEND

a. Positive identification of a piping system content shall be by lettered legend giving the name of the content in full or abbreviated form. Legends may also be as specified on drawings or in other specifications.

b. Abbreviation of words in the legend may be used onty where unavoidable due to space limitations.

c. The legend shall include the nominal operating pressure for steam, compressed air, and when specified, the pressure or temperature for other materials.

d. An arrow indicating the direction of flow shall be placed near the legend on pipes normally having a flow in one direction only. The color and size of the arrow shall be consistent with the color and size of the legend letters.

e. Legend shall be located on or adjacent to the classification color band. 
a. Legend and color classification may be accomplished by the use of approved labels conforming to this Standard and which are suitable for the temperature of the surface to which they are to be applied. Approved labels include the following.
ALL-TEMPERATURE PIPE MARKERS
W. H. Brady Company
727 West Glendale Avenue
Milwaukee, Wisconsin 53201
TEL-A-PIPES
Westline Products Division
Thomas \& Betts Company
220 South Rose Street
Los Angeles, California 90012

b. Single-word labels may be combined to form complete legends.

Individual-letter labels shall not be so combined.

c. Labels shall be installed after painting is complete.

\section{CLASSIFICATION COLOR}

a. When use of classification colors is specified, they shall conform to Table 1.

\begin{tabular}{|c|c|c|c|}
\hline \multicolumn{4}{|c|}{ Table 1} \\
\hline massiractar on & Band or w was & fegendrorow & $\begin{array}{l}\text { Approximate } \\
\text { Cofor No } \\
\text { (AED STO-595) }\end{array}$ \\
\hline Dangerous & Yellow & B7ack (17038) & 13655 (ye $110 w$ ) \\
\hline Safe & Green & Black (17038) & 14260 (green) \\
\hline
\end{tabular}

b. Paint, if used, shall conform to FS TT-E-489, Class A, for synthetic gloss enamel.

c. Classification colors shall conform to Table 2 .

\begin{tabular}{|c|c|}
\hline Table 2. Classification Colors. \\
\hline Iater tal & Collor \\
\hline Steam & Yellow \\
\hline Sanitary Water (SW) & Green \\
\hline Process Sodium Hydroxide (NaOH) & Yellow \\
\hline Raw Water (RW) & Green \\
\hline
\end{tabular}

END OF APPENDIX 
HEATING, VENTILATING, AND AIR CONDITIONING

PART 1 - GENERAL

1.1 REFERENCES

1.1.1 The following documents, including others referenced therein, form part of this Section to the extent designated herein.

1.1.1.1 Air Movement and Control Association (AMCA)

$210-85$

1.1.1.2 Underwriters Laboratories (UL)

Building Materials Directory

1993

1.2 SUBMITTALS

1.2.1 See Section 01300 of W-030-G2 for submittal procedures.

1.2.2 Approval Required

1.2.2.1 Approval data: Before delivery, submit information listed in the Approvat Data List in this Section.

1.2.3 Approval Not Required

1.2.3.1 Vendor information: Before installation, submit information 1 isted in the Vendor Information List in this Section.

1.2.3.2 Test data: Within 10 days after completion, submit the test data report specified in 3.2.1, dated and signed by the contractor who performed testing.

1.3 QUALITY ASSURANCE

1.3.1 Contractor's Quality Assurance Program: See Section 01400 of W-030-G2. Hold and Witness Point Schedule para 1.7 is not applicable to this Section 15500 work.

1.4 DELIVERY, STORAGE, AND HANDLING

1.4.1 See Section 01610 of W-030-G2 for general requirements.

1.4.2 Damaged or defaced equipment may be repaired, if repairs are acceptable to ICF KH. 


\subsection{SUBSTITUTES}

2.1.1 See Section 01630 of W-030-G2 for substitution approvals.

\subsection{EQUIPMENT}

2.2.1 Centrifugal Wall Ventilator (FN-1363): $1 / 8 \mathrm{hp}, 1640 \mathrm{rpm}, 478 \mathrm{ft}^{3} / \mathrm{min}^{2}$ minimum at $3 / 8$ in $_{2} \mathrm{O}$. The ventilator shall be the direct drive type. The motor shall be Class 1, Group D, explosion proof. Bearings shall be permanently lubricated and sealed. The ventilator shall be AMCA certified, licensed to bear the AMCA seal, and UL listed. COOK Type ACW-D Model No. 100W15DM with bird screen, or an approved substitute.

2.2.2 Exhaust Damper: Frame shall be 21 by 21 inches, 0.0516 -inch (18-gage) gaivanized steel, flangeless for indoor ductwork, with an adjustable return spring. Greenheck Model WD-400 or an approved substitute.

2.2.3 Electric Thermostat (TC 13629 8): Adjustable between 6040 and $12090^{\circ} \mathrm{F}$; Chromalox Model WR-80EP or an approved substitute.

2.2.4 Intake Damper: Operated by pressure differential to open, and adjusted to open when pressure differential in building drops below 0.1 in $\mathrm{H}_{2} \mathrm{O}$. Damper frames shall be 18-gage galvanized steel with prepunched mounting holes. Unit shall be 16 inches wide by 16 inches high. Frame shall include 16 inches high by 16 inches wide by 7 inch extension. Extension will provide filter sleeve, equipped with a 2 inch Farr $30 / 30$ filter. (F-1366), or approved substitute, with filter access door and snap latches. Blades shall be 0.025 roll formed aluminum with vinyl seals on the closing edges. Axles shall be 3/16-inch diameter zinc plated steel mounted in acetal bushings. Greenheck Model WD-400 or an approved. substitute.

2.2.5 Wall Mounted Space Heater (HC-1363): UL 1isted, $120 \mathrm{~V}, 2 \mathrm{KW}$, with. adjustable thermostat that can be set from 4055 to $90105^{\circ} \mathrm{F}$. Chromalox Type HVT-24XX or an approved substitute.

2.2.6 Air Inlet Louver: Stationary type, 16 by 16 inches with flange. Each factory assembled louver section shall have been designed to withstand $25 \mathrm{lb} / \mathrm{ft}^{2}$ wind loading. Louver shall be equipped with a framed, removable, rear mounted screen of 3/4- by 0.051 -inch expanded, flattened aluminum, and have a standard mill finish. Greenheck Model ESJ-201 or an approved substitute.

2.2.7 Equipment nameplates: Laminated plastic, 1/16-inch thick with white surface and black core. Edges beveled and smooth. Engraved nomenclature sharp and clear. Provide nameplates for FN-1363, TC-13616, and $\mathrm{HC}-1363$. 
2.2.8 Nameplate Attachments: Use screws or rivets where drilling will not Page 93 cause damage, otherwise use cement. If plastic nameplate is not suitable for installation directly on equipment, use twisted wire, using enough wire to produce 1 -inch minimum installed lengths.

PART 3 - EXECUTION

\subsection{INSTALLATION}

3.1.1 Instal1 equipment where shown on the Drawings, in accordance with manufacturer's instructions.

3.1.2 Wire the thermostat to the ventilator.

\subsection{FIELD QUALITY CONTROL}

\subsubsection{Testing HVAC Systems}

3.2.1.1 Before operating equipment perform a thorough check verifying that systems have been properly cleaned and equipment has been properly installed, lubricated, and serviced.

3.2.1.2 After the ventilator fan system is installed, place ventilator in operation in accordance with manufacturer's instructions. Verify ventilator is fully operational by resetting the temperature set point so that ventilator is in operation. After verification, return the temperature setpoint to $85^{\circ} \mathrm{F}$.

3.2.1.3 After Electric Heater is installed, adjust thermostat control and verify unit is fully operational. After verification, return the thermostat control setpoint to $50^{\circ} \mathrm{F}$.

3.2.1.4 Prepare a test data report. 


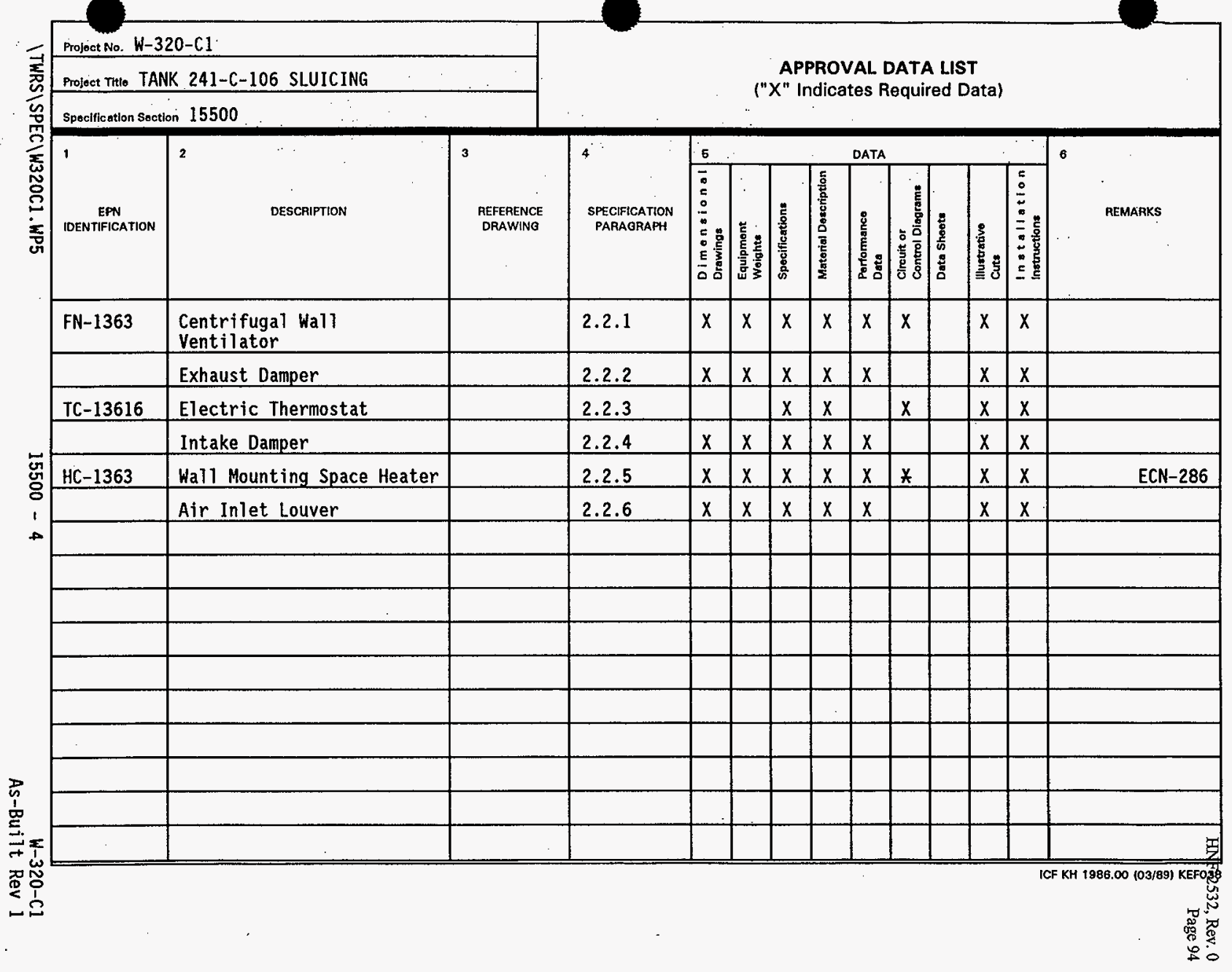




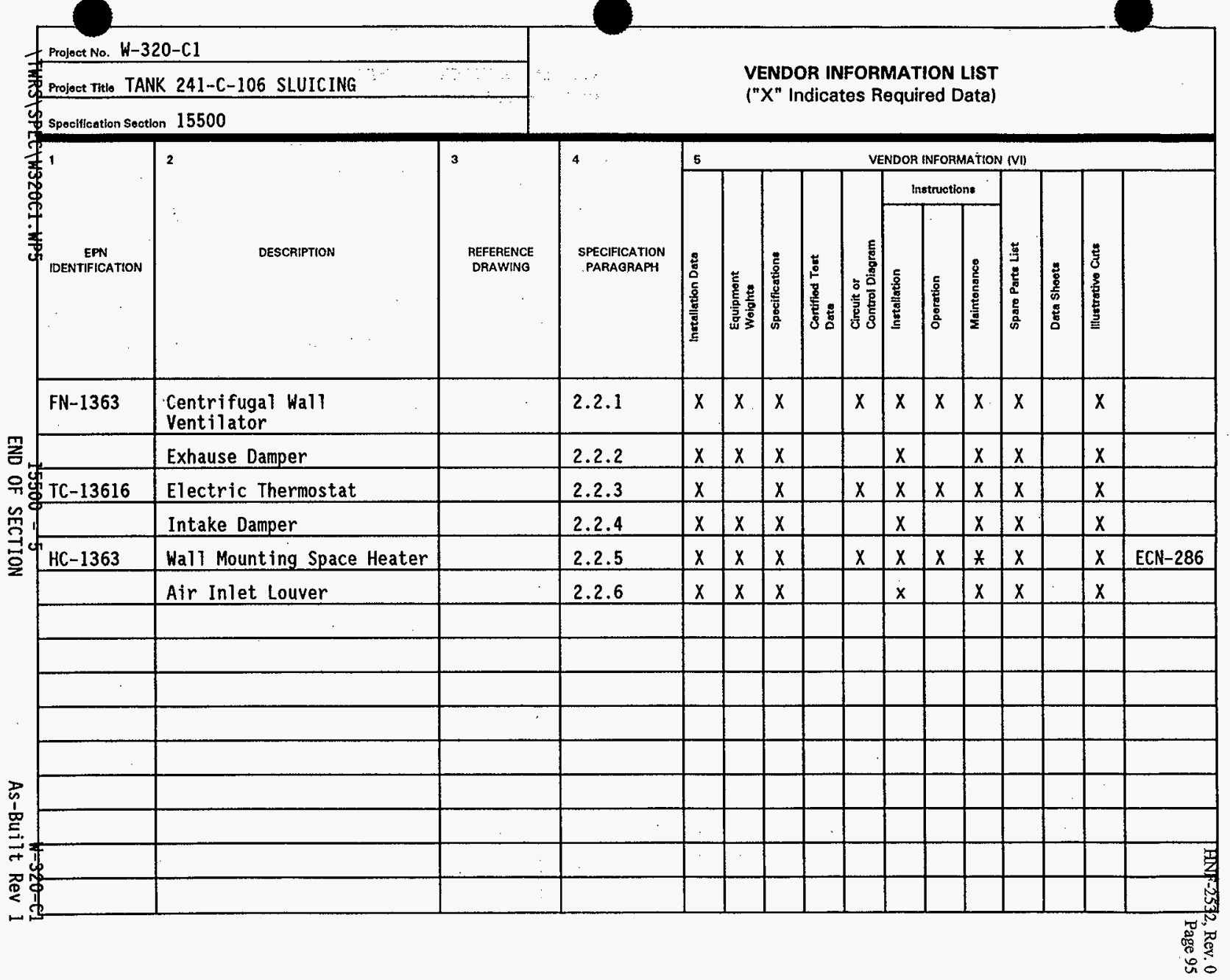




\section{SERVICE AND DISTRIBUTION}

PAKI I - GENERAL

1.1 REFERENCES

1.1.1 The following documents, including others referenced therein, form part of this Section to the extent designated herein.

1.1.1.1 American National Standards Institute (ANSI)

C80.1-1990

C80.3-1983

C82.1C-1990

1.1.1.2 Factory Mutual System (FM)

Approval Guide

1993 Edition

1.1.1.3 Federal Specifications (FS)

H-C-375B/

NOT 1

W-F-406E

W-S-896E

AMD 2

NOT 1

TT-S-00230

WW-C-566C

Circuit Breakers, Molded Case; Branch Circuit And Service

Fittings For Cable, Power, Electrical And Conduit, Metal, Flexible

Switches, Toggle (Toggle And Locks), Flush Mounted (General Specification)

Sealing Compound: Elastomeric Type, Single Component (For Calking, Sealing, And Glazing In Buildings And other Structures)

Conduit, Metal, Flexible

1.1.1.4 Institute of Electrical and Electronic Engineers (IEEE)

587-1980

Guide for Surge Voltages in Low-Voltage AC Power Circuits

1.1.1.5 National Electrical Manufacturers Association (NEMA)

FB 1-1988

Fittings, Cast Metal Boxes, and Conduit Bodies for Conduit and Cable Assemblies

FU $1-1986$

Low Voltage Cartridge Fuses 
ICS 6-1988

Rev. 1

KS $1-1990$

RN 1-1989

ST 20-1986

WD 1-1983 (R 1989)
Enclosures for Industrial

Controls and Systems

Enclosed Switches

Polyvinyl-Chloride (PVC)

Externally Coated Galvanized Rigid

Steel Conduit and Intermediate Metal

Conduit

Dry-Type Transformers for General

Applications

General Requirements for Wiring Devices

1.1.1.6 National Fire Protection Association (NFPA)

$70(1993)$

101 (1994)

1.1.1.7 Underwriters Laboratories (UL)

Electrical Appliance and

Utilization Equipment Directory

Electrical Construction

Materials Directory

Fire Resistance Directory

797-1993
National Electrical Code

Code for Safety to Life From Fire in Buildings and Structures
1993 (Vol I \& II)

Electrical Metallic Tubing

\section{$1.2, \quad$ SUBMITTALS}

1.2.1 See Section 01300 of $W-030-G 2$ for submittal procedures.

1.2.2 Approval Required: None

1.2.3 Approval Not Required

1.2.3.1 Vendor information: Before installation, submit information 1isted in the Vendor Information List in this Section.

1.3 QUALITY ASSURANCE

1.3.1 Contractor's Quality Assurance Program: Sée Section 01400 of W-030-G2.

1.3.2 Electrical/Electronic Product Acceptability

1.3.2.1 Products shali. be identified (1isted) for their intended use in one of the following, and bear the organization's label.

a. UL Electrical Construction Materials Directory 
b. UL Electrical Appliance and Utilization Equipment Directory

c. FM Approval Guide

In the abseñce of a label, submit documentation that verifies product listing.

1.3.2.2 When products with one of the above listings are not available, products tested and certified by another agency are acceptable, provided that the following conditions are satisfied.

a. The agency has been qualified for product testing in accordance with a national code or standard, and is nationally recognized.

b. Product testing was accomplished in accordance with a national code or standard.

1.3.3 Misrepresented Products: See Section 01400 of W-030-G2 for required measures to prevent the use of misrepresented products.

1.3.4 Deliverable Documentation: The following documents and records, required by this Section, shall be delivered to ICF KH in accordance with Section 01720 of W-030-G2.

Document

Electrical Test Results

\section{Paragraph}

3.3 .1 .1

1.4 DELIVERY, STORAGE, AND HANDLING

1.4.1 See Section 01610 of $W-030-G 2$ for general requirements.

PART 2 - PRODUCTS

2.1 SUBSTITUTES

2.1.1 See Section 01630 of W-030-G2 for substitution approvals.

2.2 MATERIALS

2.2.1 Solderless Connectors and Terminal Lugs: Pressure type, rated for use with copper or aluminum conductors, with insulating caps or covers rated for system utilization voltage. Connectors shall be types specified below.

2.2.1.1 For conductors No. 8 AWG and smaller:
a. Idea] Industries, Incorporated "Wire-Nuts."
b. Thomas and Betts Company "Sta-Kon."
c. 3M Company "Scotchlok." 
2.2.1.2 For conductors No. 6 AWG and larger:

a. Burndy Engineering Company "Screw Pressure Connectors" or "Hydent."

b. Thomas anci Betts Company "Lock-tite."

2.2.2 Conduit, Fittings, and Boxes

2.2.2.1 Conduit: ANSI C80.1, C80.3, FS WW-C-566C, and UL 797.

2.2.2.2 PVC coating on rigid steel conduit: NEMA RN 1, Type A-40, factory applied.

2.2.2.3 Flexible metal conduit shall have an integral ground conductor.

2.2.2.4 Fittings for rigid steel and EMT conduit: NEMA FB 1. Use compression type, threadless fittings with EMT.

2.2.2.5 Fittings for flexible metal conduit: FS W-F-406E, squeeze type.

2.2.2.6 Use "Myers" type watertight fittings, or sealing type locknuts, for conduit entries into side or top of the NEMA ICS 6 Type 4 enclosure,

2.2.2.7 Interior lighting fixture outlet boxes: 4-inch octagonal pressed steel.

2.2.2.8 Exterior lighting fixture outlet boxes: Cast with threaded hubs.

2.2.2.9 Interior light switch and receptacle boxes: 4 by $2-1 / 8$ by $2-1 / 8$-inches

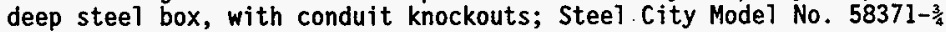
(WESCO No. 78-5991-17955).

2.2.3 Conductors: Stranded copper with Type THWN/THHN or XHHW insuTation, of type and AWG size specified on the Drawings.

2.2.4 Wiremarkers: Imprinted tubular plastic.

2.2.5 Wire Pulling Compound: Electro Compound Company "Y-er Eas," or American Polywater Corporation "Polywater."

2.2.6 Tape

2.2.6.1 Plastic insulating tape: 3M Company "Scotch No. 33+."

2.2.6.2 Conduit protection tape: 3M Company "Scotchrap No. 50."

2.2.7 Insulating Putty: 3M Company "Scotchfil," General Electric Company No. 8389, or Kearney Company "Airseal." .

2.2.8 Duct Sealing Compound: Porcelain Products Company "Sealex."

2.2.9 Penetration Sealants: RTV Silicone foam; Semco "PR855 RTV", Dow Corning "Type 3-6548 RTV", or General Electric "Type RTV 800." 
2.2.10.1 Individual conduit hangers: Factory made springable wrought steel clamps, or malleable iron split and hinged rings.

2.2.10.2 Lighting fixture and equipment supports: 1-1/2-inch channe1; Unistrut or Kindorf.

2.2.10.3 Expansion Anchors: Hilti Fastening Systems "Kwik-Bolt II", or ITW-Ramset "Trubolt Wedge Anchor."

2.2.11 Equipment Nameplates: Laminated plastic, 1/16-inch thick with white surface and black core. Edges beveled and smooth. Engraved nomenclature sharp and clear.

2.3 EQUIPMENT

2.3.1 Electrical equipment shall be $\mathrm{PCB}$ free.

2.3.2 Equipment enclosures: NEMA ICS 6 Type 3, 3R or 4 as shown on the Drawings.

2.3.3 Mini-Power Center: Rated as shown on the drawings, with manufacturer's standard fuil capacity taps and insulation, in accordance with UL 1062. Surface mounted as shown on the Drawings.

2.3.3.1 Provide with main circuit breaker.

2.3.3.2 Branch circuit breakers: FS W-C-375B molded case manufacturer's type, with thermal magnetic trips. Number, rating, and arrangement are shown on the Drawings.

a. Permanently number branch circuits. Number tabs shall not be attached to, or be part of, circuit breaker.

b. Branch circuit breaker positions marked "space": Bussed for future circuit breakers. Provide removable single pole filler plates for spaces shown on drawings.

c. Provide a directory card holder and card for branch circuit load identification.

2.3.4 Disconnect Switches: NEMA KS 1, fusible heavy duty Type HD, horsepower rated for $600 \mathrm{~V}$ ac as noted on the Drawings. Building Service

Disconnect shall be 3-pole with grounding lug and solid neutral assembly in NEMA 4 enclosure and rated as service entrance equipment. 
2.3.5 Lighting Fixtures: Furnish with parts and fittings necessary to instal Page 101 in accordance with manufacturer's instructions:

2.3.5.1 Fixture types:

a. Indoor: Industrial type fluorescent fixture with two $40 \mathrm{~W}$ lamps, rapid start ballast, and gasketed acrylic prismatic lens suitable for use in wet or corrosive atmospheres, as shown on the Drawings.

b. Outdoor: Low Pressure Sodium lamp with $120 \mathrm{~V}$ ballast, globe, guard and bracket mounting as shown on the Drawings.

2.3.5.2 Photoelectric cell controls: Diecast aluminum weatherproof housing with hermetically sealed light sensitive element, having manually adjustable light level slide with turn-on range of 2 foot-candles.

2.3.6 Receptacies: NEMA WD 1 Designation 5-15R, duplex, ivory, GFCI, weatherproof, rated $15 \mathrm{~A}, 120 \mathrm{~V}$, 3-wire, grounding type, with screw terminals arranged for side wiring. Self-grounding receptacles may be used.

2.3.7 Toggle Switches: FS W-S-896E, weatherproof, rated $20 \mathrm{~A}, 277 \mathrm{~V}$, with conventional handles, and screw terminals arranged for side wiring; Perfect Line Model No. SW20-1 (WESCO No. 78-5055-20062).

2.3.8 Receptacle Plates: Vertical device mount cover, for GFI single receptacle; Red Dot Model No. CCGV (WESCO No. 04-2269-35022).

PART 3 - EXECUTION

$3.1:$ PREPARATION

3.1.1 Field Measurements: Drawings show desired approximate 1ocations of equipment. Actual locations, distances, and levels shall be governed by field conditions.

\section{$3.2 \quad$ INSTALLATION}

\subsubsection{General}

3.2.1.1 Perform work in accordance with NFPA 70.

3.2.1.2 Fasten equipment to structural members of building or metal supports attached to structure, or to concrete surfaces.

a. Use clamping devices for attaching to structural steel, or, when clamping is impracticable, obtain written permission from ICF KH to weld, drill, or cut structural members for attachments.

b. Fasten equipment to concrete or masonry with expansion anchors.

c. Attach to drywall by screws into studs, and to metal wall panels by weld studs, bolts, or self-tapping metal screws. 
d. Locate equipment, boxes, and conduit approximately where shown in Page 102 relation to equipment served.

e. Do not install conduit raceways and boxes in positions that interfere with work done by other trades.

f. Identify components with nameplates bearing legends shown on the Drawings.

g. Attach nameplates on or near equipment, with metal screws. Attach panelboard nameplate on front, above door.

3.2.1.3 Use appropriate calibrated special tools, recommended by manufacturers, when installing unusual or unique devices or systems.

3.2.2 Grounding Systems

3.2.2.1 Underground conductors, electrodes, and connections: Install in accordance with the Drawings. Make joints connecting copper and galvanized steel conductors above grade and in dry locations.

Connections may be made with exothermic welds or ground rod clamps.

3.2.2.2 System and equipment grounding: Solidly ground the neutral conductor of 3-wire, 1-phase and 4-wire, 3-phase, wye-connected distribution systems. Ground equipment in accordance with NFPA 70.

3.2.2.3 Static grounding: Ground steel building columns to the grid, as shown on the Drawings.

\subsubsection{Conduit}

3.2.3.1 Use rigid steel where subject to mechanical damage, or installed in concrete floors and walls, or exposed to weather. Electrical metallic tubing may be used elsewhere.

3.2.3.2 Install concealed conduits as directly as possible and with bend radii as long as possible. Install exposed conduit parallel with or at right angles to building lines.

3.2.3.3 Make elbows, offsets, and bends uniform and symmetrical. Bend conduit with approved bending devices.

3.2.3.4 Cut conduit ends square, ream, and remove burrs. Conduit shall be clean, dry, and free of debris. Immediately after installation, plug or cap exposed ends with standard accessories until wires are installed.

3.2.3.5 Use 1-hole clamps equipped with clampbacks, or Unistrut with clamps, to secure conduits.

3.2.3.6 Flexible conduit:

a. Use to make connections to motors and other equipment subject to vibration. Use liquidtight flexible metal conduit where conduit and fittings are installed outdoors or exposed to moisture or chemical fumes indoors. 
b. Use in 4 foot maximum lengths for other equipment, with approval ofage 103 ICF KH.

c. Use for fluorescent lighting fixtures in lengths up to 6 feet.

3.2.3.7 Seal openings around conduit at exterior wall penetrations and penetrations of walls which form boundaries between adjoining ventilation zones, using specified sealant. Make seals waterproof, and finish sealant flush with surrounding wall surfaces.

3.2.3.8 Where routing is parallel with hot water or steam pipes, maintain 6 inches minimum clearance from pipe covering. Where not run parallel with pipe, it is acceptable to run closer than 6 inches, providing conduit does not touch pipe covering.

3.2.3.9 Insta11 PVC coated conduit in accordance with manufacturer's recommendations. Repair coating, damaged during handling or installation using PVC paint recommended by conduit manufacturer.

3.2.4 Boxes, Enclosures, and Wiring Devices

3.2.4.1 Install boxes firmiy in position and plumb.

3.2.4.2 Install extension ring with blank cover on flush mounted junction boxes where box serves permanently installed equipment.

3.2.4.3 Flush mount junction boxes served by concealed conduit.

3.2.4.4 Install dust covers on junction, pull, and outlet boxes, and other types of wiring outlets at initial installation. Replace with permanent covers or devices after wires are installed.

\subsubsection{Conductors}

3.2.5.1 Do not bend cables installed in wireways to less than manufacturer's recommended minimum bending radii. Bind power and control circuits separately with nylon cable ties, at 18-inch intervals. Lay cables in wireways in straight parallel lines, and avoid crossing.

3.2.5.2 Identify conductors, by wire numbers shown on the Drawings, with wiremarkers. Attach wiremarkers at termination points within 2 inches of wire terminations. Marker nomenclature shall be visible without moving wires or markers.

3.2.5.3 Paint or pressure-sensitive colored tape may be used for coding conductors instead of colored insulation on No. 8 AWG and larger wire for phase (ungrounded) conductors, and No. 4 AWG and larger wire for neutral (grounded) conductors and equipment grounding conductors only. Maintain phase color coding, in accordance with the following table, for branch and feeder circuits up to and including equipment connections. Use colored tape to properly code existing conductors whose color does not comply. 


\begin{tabular}{|c|c|c|}
\hline . concuct or or g g gr & 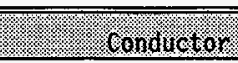 & Wrsulat on co or \\
\hline $\begin{array}{l}480 Y / 277 \mathrm{~V}, 3 \text {-phase } \\
\text { systems, transformers, } \\
\text { panels }\end{array}$ & $\begin{array}{l}\text { Phase A } \\
\text { Phase B } \\
\text { Phase C } \\
\text { Neutral } \\
\text { Equipment ground }\end{array}$ & $\begin{array}{l}\text { Red } \\
\text { Orange } \\
\text { BTack } \\
\text { White or Gray } \\
\text { Green (or bare) }\end{array}$ \\
\hline $\begin{array}{l}120 / 240 \mathrm{~V}, \\
\text { single-phase } \\
\text { transformers, panels, } \\
\text { switchboards, etc. }\end{array}$ & $\begin{array}{l}\text { Hot Number } 1 \\
\text { Hot Number } 2 \\
\text { Neutral } \\
\text { Equipment ground }\end{array}$ & $\begin{array}{l}\text { Black } \\
\text { Red } \\
\text { White or Gray } \\
\text { Green (or bare) }\end{array}$ \\
\hline
\end{tabular}

3.2.5.4 Use lubricant recommended by the cable manufacturer, or wire pulling compound specified, when pulling wire and cable through conduit.

3.2.5.5 Do not install or handle wires with thermoplastic insulation or jacket when ambient temperature is $15^{\circ} \mathrm{F}$ or below.

3.2.5.6 Install and mark direct burial cable in accordance with the Drawings.

3.2.6 Splices, Taps, and Cable Terminations

3.2.6.1 Make splices and taps in building wire with solderless connectors specified in 2.2.1. Use connectors in accordance with the manufacturer's instructions.

3.2.6.2 Use plastic insulating tape for uninsulated splices and taps. Apply tape to thickness at least equal to conductor insulation. Where bolted splice or connection presents irregular surface, apply insulating putty to joints before taping.

3.2.6.3 Use crimp-on type ring or spade lugs with turned up legs for wire terminations of stranded conductors to binder screw or stud type terminals. Lugs shall have insulated sleeves.

3.2.7 Lighting Fixtures: Mount suspended fixtures as shown on the Drawings. Use fixture stud if lighting fixture is suspended from outlet box.

3.2.8 Motor Operated Equipment: Connect fan in accordance with the Drawings, this Section, and manufacturer's instructions. Install wiring to devices which do not appear on the Drawings, but are included in installation shown on the manufacturer's drawings.

3.3 FIELD QUALITY CONTROL

3.3.1 Testing

3.3.1.1 Furnish equipment and instruments required to perform testing.

3.3.1.2 Test equipment and wiring for continuity and unintentional grounds, and verify proper phase sequence and voltage at equipment served before attempts are made to operate equipment. Notify ICF KH before start of tests. Record the results. 
HNF-2532, Rev. 0

a. Megger conductors rated $600 \mathrm{~V}$ and used for services, feeders or Page 105 branch circuits over $150 \mathrm{~V}$ to ground, phase-to-phase, and phase-to-ground. Minimum acceptable value of insulation resistance is 200 megohms. The megger manufacturer's instruction booklet, furnished with megger, shall be used for conducting tests. Disconnect devices not capable of withstanding voltage or current of megger test, such as indicating instruments, relays and lamps, before test is made. Voltage output of megger shall be $1000 \mathrm{~V}$ : dc nominal.

b. Test wiring operating at less than $150 \mathrm{~V}$ to ground for continuity and unintentional ground. Resistance shall not exceed 1 ohm on continuity checks.

3.3.1.3 Motors: Check for correct rotation.

3.3.2 Reconnect devices disconnected during testing. 


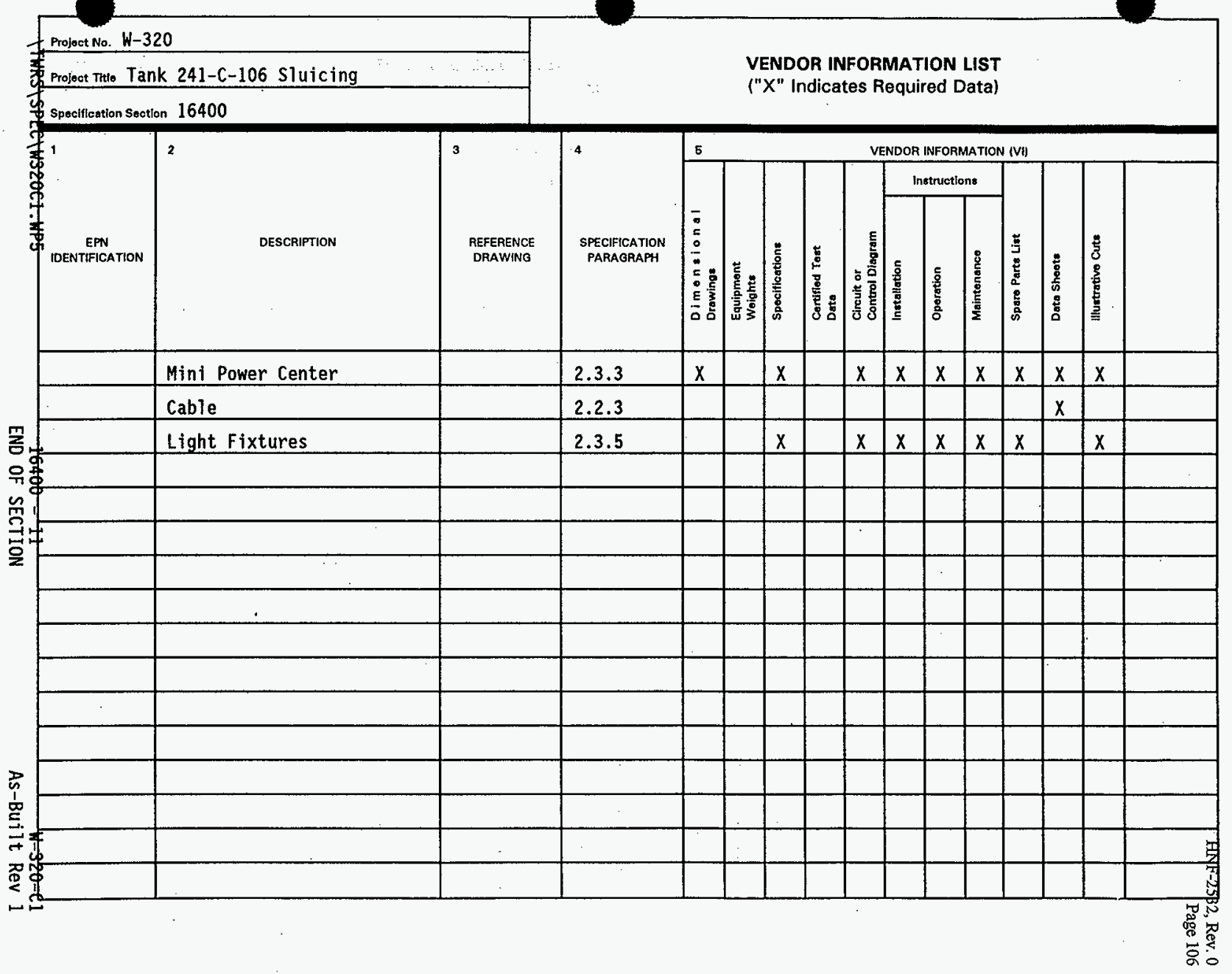


SECTION 16640

\section{CATHODIC PROTECTION}

PART 1 - GENERAL

\subsection{REFERENCES}

1.1.1 The following documents, including others referenced therein, form part of this Section to the extent designated herein.

1.1.1.1 American National Standards Institute (ANSI)

C80.1-1990

Rigid Steel Conduit--Zinc Coated

1.1.1.2 American Society for Testing and Materials (ASTM)
B $8-90$
Concentric-Lay-Stranded Copper
Conductors, Hard, Medium-Hard, or Soft
C 518-91
Test Method for Steady-State Heat Flux Measurements and Thermal Transmission Properties by Means of the Heat Flow Meter Apparatus
D 1621-73 (1979)
Test Method for Compressive Properties of Rigid Cellular Plastics
D $1622-88$
Test Method for Apparent Density of Rigid Cellular Plastics
D 2842-69 (1990)
Test Method for Water Absorption of Rigid Cellular Plastics
D 2856-87
Test Method for Open Cell Content of Rigid Cellular Plastics by the Air Pycnometer

1.1.1.3 Factory Mutual System (FM)

Approval Guide

1993 Addition

1.1.1.4 Federal Specifications (FS)

W-C-1094A

Conduit And Conduit Fittings Plastic, Rigid

$W-F-406 E$

Fittings For Cable, Power, Electrical And Conduit, Metal, Flexible 
TT-S-00230C

AMD 2
Sealing Compound: Elastomeric

Type, Single Component (For Caulking, Sealing, And Glazing In Buildings And Other Structures)

WH-C-566C

1.1.1.5 National Electrical Manufacturers Association (NEMA)

FB 1-1988

FU $1-1986$

ICS 6-1988

Rev. 1

KS 1-1990

RN 1-1989

WC 5-1973 (R 1985)
Fittings, Cast Metal Boxes, and Conduit Bodies for Conduit and Cable Assemblies

Low Voltage Cartridge Fuses

Enclosures for Industrial

Controls and Systems

Enclosed Switches

Polyvinyl-ChToride (PVC)

Externally Coated Galvanized Rigid

Steel Conduit and Intermediate Metal Conduit

Thermoplastic-Insulated Wire and Cable for the Transmission and Distribution of Electrical Energy

1.1.1.6. National Fire Protection Association (NFPA)

70 (1993)

National Electrical Code

1.1.1.7 Underwriters Laboratories (UL)

Electrical Appliance and 1993

Utilization Equipment Directory

Electrical Construction

Materials Directory

1.2 SUBMITTALS

1.2.1 See Section 01300 of W-030-G2 for submittal procedures.

1.2.2 Approval Required

1.2.2:1 Approval data: Before delivery, submit information listed in the Approval Data List in this Section.

1.2.2.2 Test Station Sketches: Before installation, submit sketches required in 3.2.3.3. 
1.2.3 Approval Not Required

1.2.3.1 Vendor information: Before installation, submit information 1 isted in the Vendor Information List in this Section.

\subsection{QUALITY ASSURANCE}

1.3.1 Contractor's Quality Assurance Program: See Section 01400 of W-030-G2.

1.3.2 Electrical/Electronic Product Acceptability

1.3.2.1 Products shall be identified (1isted) for their intended use in one of the following, and bear the organization's label.
a. UL Electrical Construction Materials Directory
b. UL. Electrical Appliance and Utilization Equipment Directory
C. FM Approval Guide

In the absence of a label, submit documentation that verifies product listing.

1.3.2.2 When products with one of the above listings are not available, products tested and certified by another agency are acceptable, provided that the following conditions are satisfied.

a. The agency has been qualified for product testing in accordance with a national code or standard, and is nationally recognized.

b. Product testing was accomplished in accordance with a national code or standard.

1.3.3 Misrepresented Products: See Section 01400 of W-030-G2 for required measures to prevent the use of misrepresented products.

1.3.4 Deliverable Documentation: The following documents and records, required by this Section, shall be delivered to Construction Document Control in accordance with Section 01720 of W-030-G2.

Document

Existing Pipe Exothermic

Weld Documents

New Pipe Exothermic Weid Documents

Functional Test of Reference Electrodes
Paragraph

3.2.6.1c

$3.2 .6 .2 \mathrm{c}$

Page 109 


\section{$2.1 \quad$ SUBSTITUTES}

Z.1.1 See Section 01630 of $W-030-G 2$ for substitution approvals.

2.2 MATERIALS

2.2.1 Terminal Lugs: Crimp type with ring tongue and insulated sleeve, for wire sizes No. 10 AWG and smaller, non-insulated sleeve for No. 8 AWG and larger, rated for use with copper conductors.

2.2.2 Compression Splice Connectors: For use with cable splice or cable tap, size as required. Burndy Company "Crimpit."

2.2.3 Exothermic Fusion Weld Mold, Low Emission Type with electric starter, Erico Products "Cadweld," Part Number XLB971A1.

2.2.3.1 Existing Pipe: For connection of pipe test conductors. Size and type as required, Erico Products "Cadweld" or an approved substitute.

a. Exothermic weld metal: Low-emission type as recommended by the weld mold manufacturer.

2.2.3.2 New pipe: For connection of pipe test conductors, bonding jumpers, and negative return cables. Erico Products "Cadweld," Mold Part No. XLLMCEGIH.

a. Exothermic weld metal: Low-emission type, "Cadwe Id" No. XL No. 90 with igniters and filters.

b. Sleeve for use with No. 8 AWG conductor: "Cadweld" No. CAB-133 11 .

2.2.4 Pipe Ground Clamp Connector: Bronze, size as required, Teledyne Penn-Union, Catalog No. GPL.

2.2.5 Conduit and Fittings

2.2.5.1 Outdoor above ground: ANSI C80.1.

2.2.5.2 Underground power: ANSI C80.1, PVC coated in accordance with NEMA RN 1, Type A-40, factory applied.

2.2.5.3 Underground: For use with test stations and anode junction boxes, FS W-C-1094A, Type II PVC (ScheduTe 40), 6 inch.

2.2.5.4 Flexible metal and fittings: FS WW-C-566 and FS W-F-406.

2.2.5.5 Fittings for rigid steel conduit: NEMA FB 1 . 
2.2.6.1 Direct current (dc): ASTM B 8 and NEMA WC 5 stranded copper, $600 \mathrm{~V}$ rating, high molecular weight low density polyethylene, Type "CP." Size as specified on the Drawings.

2.2.6.2 Alternating current (ac): Stranded copper, $600 \mathrm{~V}$ rating, Type THHN/THWN insulation. Size as specified on the Drawings.

2.2.6.3 Grounding: Bare solid copper, No. 6 AWG.

2.2.7 Ground Rod: Galvanized stee1, $5 / 8$ inch by 8 foot minimum.

2.2.8 Conductor Splice Kit: Scotchcast Brand, Catalog No. 82-B1 and 90-B1.

2.2.9 Tape

2.2.9.1 Plastic insulating: $3 / 4$ inch wide, Scotch No. $88,3 M$ Company.

2.2.9.2 Electrical splice insulating: Self-vulcanizing rubber, $3 / 4$ inch wide.

2.2.10 Plastic Sheet Marker: Yellow warning tape, 6 inches wide, no printing on tape, Reef Industries.

2.2.11 Insulating Boot: Splice insulator, Thomas and Betts, Type MSC.

2.2.12 Wiremarkers: Tubular plastic, imprinted or typed with indelible ink, or plastic tags typed with indelible ink, fastened securely to wire with plastic wire ties.

2.2.13 Cable Marker: Metal auger, flush with grade type, 17-inch long by 6-inch circular top with raised words "CATHODIC PROTECTION." A.B. Chance Company, Catalog No. C554-0001 with installation tool, Catalog No. CWFA.

2.2.14 Rigid Polyurethane Insulation: Sprayed foam-in-place 2-component system with minimum apparent overall density of $2.4 \mathrm{lb} / \mathrm{ft}^{3}$ in accordance with ASTM D 1622, approximately $95 \%$ closed cells in accordance with ASTM D 2856, water absorption approximately $0.05 \mathrm{lb} / \mathrm{ft}^{2}$ of surface area in accordance with ASTM D 2842, "k" factor of approximately

$0.15 \mathrm{Btu} \cdot$ in $/ \mathrm{h} \cdot \mathrm{ft}^{2} \cdot{ }^{\circ} \mathrm{F}$ at $75^{\circ} \mathrm{F}$ after aging 10 days at $140^{\circ} \mathrm{F}$ in accordance with ASTM C 518, and minimum compressive strength of $45 \mathrm{lb} / \mathrm{in}^{2}$ parallel to rise and $27 \mathrm{ib} / \mathrm{in}^{2}$ perpendicular to rise when tested in accordance with ASTM D 1621. Polythane Systems, Incorporated urethane foam PSI-S200-25 systems, Polymer Development Laboratories, Incorporated 110 system, $3 \mathrm{lb} / \mathrm{ft}^{3}$ density, or Burtin Urethane Corporation "Buc 114 ", $3 \mathrm{lb} / \mathrm{ft}^{3}$ density.

2.2.15 PVC conduit coating touch-up compound: "Plastic-Bond."

2.2.16 Survey Marker Nameplate: Brass, 2-inch diameter, 5/8-inch by 2-1/2-inch shank, Surveyors Service Company.

2.2.17 Sealant: FS TT-S-00230, clear RTV silicone. 
2.2.18 Connector: Split bolt. (For use in anode junction boxes.)

2.2.19 Duct Sealing Compound: "Sealex," Porcelain Products Company.

2.2.20 Equipment Nameplates: Laminated plastic, 1/16-inch thick with white surface and black core. Edges beveled and smooth. Engraved nomenclature sharp and clear.

2.2.21 Liquid epoxy coating, Scotchkote 312 by $3 M$ Company or approved substitute.

\subsection{EQUIPMENT}

2.3.1 Electrical equipment shall be PCB free.

2.3.2 Anodes: High silicon, chromium iron, 2-3/16 by 24 inch with No. 8 AWG stranded copper lead wire having high molecular weight, poiyethylene (HMW PE) insulation. Lead length 20 feet. Anodes prepackaged in 8 by 48 inch steel canister with coke breeze backfill. Durichlor 51 Anode Company, Type TAB.

2.3.3 Disconnect Switch: NEMA KS 1, heavy duty type, fusible, $240 \mathrm{~V} \mathrm{ac}, 30 \mathrm{~A}$ rating, 2-pole with NEMA ICS 6 Type 3R enclosure. Fuses shall be in accordance with NEMA FU 1, cartridge type, dual element, UL Class RK5. Provide with one $15 \mathrm{~A}$ fuse and slug for neutral fuse clip.

2.3.4 Test station, high impact plastic housing, 9 terminal removable plastic terminal board, removable green cover, $7-3 / 4$ inches in diameter, 5 inches high, Street Fink $C P$ Test Station, manufactured by Cott Manufacturing Company or an approved substitute.

2.3.5 Anode Junction Box: Same as Test Station, except terminal board not required.

2.3.6 Permanent Underground Reference Electrode: Saturated gelled copper-copper sulfate with cotton bag and backfill mix, 30 year design life, EI Electrochemical Devices, Incorporated, EDI Model UL-CUG-LWO20 or an approved substitute. Provide with 20 feet of No. 14: AWG HMW/PE insulated lead wire.

\subsubsection{Rectifier}

2.3.7.1 General requirements: Rectifier and associated equipment shall operate and deliver rated capacity, without exceeding temperature 1 imitations specified, when operating in following environment.

a. Operating Environment

1) Location: Outdoors in direct sunlight.

2) Ambient temperature range: -20 to $131^{\circ} \mathrm{F}$.

3) Relative humidity: 100\%. 
4) Dust: Exposure to dust particulate (sandstorm). 
5) Precipitation: Driving rainstorm.

6) Snow: Accumulation of sleet or snow.

\subsubsection{Design Requirements}

\section{a. Rating}

1) Line input voltage: $120 \mathrm{~V}$ ac.

2) Line frequency: $60 \mathrm{~Hz}$.

3) Number of phases: Single-phase.

4) Output voltage: $24 \mathrm{~V} \mathrm{dc}$.

5) Output current: $12 \mathrm{~A}$.

b. 0il-immersed type.

c. Suitable for mounting on concrete slab.

d. Transformer: Separate primary and secondary windings futly rated for maximum capacity. Electrostatic shield between primary and secondary windings.

e. Silicon stacks: Connected in full wave bridge circuit configuration, and rated a minimum of 800 peak inverse volts. Provide voltage surge protection with ac and dc lightning arresters and metal varistors across secondary lines to the stack, and across the dc output of the rectifier. Provide heat sinks sized to keep diode junction and case temperatures below temperatures that could cause failure.

f. Efficiency filter: Incorporate in rectifier to increase efficiency of unit.

g. Enclosure: NEMA ICS 6, Type 4.

h. Current carrying pressure connections, such as terminal studs and current shunt connections, shall have thin layer of conductive grease applied to contact surfaces to prevent oxidation.

\subsubsection{Construction requirements}

a. Construct to permit transformer, stacks and other internal components to be immersed in oil. Inside of enclosure shall be accessible through cover mounted on top. Attach cover to cabinet by hinges and provide with quick-release clamps and padlock clasp or other means of locking cabinet. Provide stop to limit swing of lid when opened. Provide positive, oil-resistant, compressible sealing lid gasket. Cork and sponge materials are not acceptable. Gasket joints shall not have gaps. 
b. Provide panel for mounting terminals, circuit breakers, shunts, Page 115 etc. Board inside panel shall be micarta or similar insulating material, supported on 4 edges.

c. Enclosure anủ apiurtenances: Approved for use in specified environmental conditions. Materials and methods used in construction and fabrication of rectifier shall be in accordance with NEMA requirements for specified service. Internal components and connections of rectifier shall be immersed under 3 inches of 0il, minimum.

d. Enclosure shall be steel, provided with oil drain plug. 0il level shall be clearly marked.

e. Finish enclosure inside and outside with 1 coat of epoxy red oxide primer and 2 coats of gray baked enamel.

f. Provide engraved, manufacturer's standard nameplates on rectifier. Nameplate information shall include specified rating data.

\subsubsection{Instrumentation}

a. Combination digital volt-ammeter or separate digital voltmeter and ammeter, rectangular. Scale shall be linear, and range from 0 to $125 \%$ minimum of rated voltage and current.

b. Meter circuit shall have momentary-off-momentary disconnect switch which may be closed by operator when readings are being taken.

c. Ammeter shunt: Size in accordance with ampere rating of the rectifier.

2.3.7.5. Voltage and current control

a. Output voltage manually controlled. Transformer taps shall have tap-changing devices for manual operation to permit 18 equal steps minimum of adjustment.

b. Power supply pulse generator for instant-off potential measurements, $115 \mathrm{~V}$ ac, $60 \mathrm{~A}$ rating, with terminal lugs sized for No. 4 AWG minimum conductors. MC Miller Company, Catalog No. WFA005 (mount in rectifier control panel).

2.3.7.6 Protection: Furnish with following protective devices and equipment.

a. AC thermal magnetic input circuit breaker: Mounted within control panel to provide short-circuit and overload protection.

b. DC fuse: Installed in positive lead. Fuse shall be accessible from front of panel.

c. DC valve-type arrester: For $150 \mathrm{~V}$ maximum line-to-ground fault voltage. 
d. AC input surge (lightning) arresters.

e. Ground lug: Installed on cabinet so cabinet may be connected to grounding system. Size ground lug for No. 6 AWG copper ground cable.

2.3.7.7 Output terminals

a. 2 negative and 4 positive stud type terminals mounted on front of control panel, appropriately marked.

b. External shunts on output (positive and negative) circuits indicated above. Output shunts of same rating as ammeter external shunt.

2.4 SOURCE QUALITY CONTROL

2.4.1 Factory test and inspect the rectifier specified in 2.3.6 to establish that design and construction are in accordance with this Section and applicable standards, and to determine that equipment is free from electrical or mechanical defects.

\section{PART 3 - EXECUTION}

\section{$3.1 \quad$ PREPARATION}

3.1.1 Field Measurements: Scale dimensions on the Drawings show desired and approximate location of equipment, actual locations, distances, and levels shall be governed by field conditions.

\subsection{INSTALLLATION}

\subsubsection{General}

3.2.1.1 Perform work in accordance with NFPA 70.

3.2.1.2 Use appropriate calibrated special tools when installing devices for which special installation tools are recommended by manufacturer.

3.2.2 Anodes: Install to depth of 7 feet, \pm 6 inches.

3.2.2.1 Use subsurface radar scanning machine to locate underground structures before auguring. Hand auger holes for anodes that are located above or within 4 feet from underground tanks or structures. Power auger may be used for other anodes. Maximum auger size, 12 inches.

3.2.2.2 Lower anodes to bottom of holes by rope, and center within holes. Do not use lead wires to lower anodes. If temporary casings have been used, slowly withdraw casings while backfilling.

3.2.2.3 Backfill by sluicing with water.

3.2:2.4 Repair damaged anode lead wire insulation by encapsulation with epoxy resin using conductor splice kit. 
3.2.2.5 Connect anode lead conductor to anode header cable using compression Page 117 splice connector and conductor splice kit.

3.2.3 Test Station or Anode Junction Box: Install where shown on the Drawings. Stamp or engrave survey marker nameplate, using $3 / 16$ inch minimum ietters, TEST STATION $T$ (numbers shown on the Drawings) or ANODE JUNCTION BOX AJB (number shown on the Drawings).

3.2.3.1 Identify terminals in the test station with nameplates. Engrave with pipe designation or words "Reference Electrode." Character height $1 / 8$ inch. Secure nameplates to the terminal board by use of clear RTV silicone sealant.

3.2.3.2 Place the test station or anode junction box in the 6-inch PVC conduit, and seal as shown on the Drawings.

3.2.3.3 A field sketch of each test station shall be made to show the configuration of new pipes, and existing pipes exposed by the excavation. This sketch shall also show the proposed connection of pipe test conductors, the location of pipe bonding jumpers (if required by the Drawings) and the location of the reference electrode.

3.2.4 Permanent Underground Reference Electrode: (See Appendix A for testing before installation.)

3.2.4.1 Follow manufacturer's instaliation instructions. Do not allow the reference electrode to freeze.

3.2.4.2 Install reference electrode horizontally, 6 to 12 inches below the outer surface of pipe. For configuration of 2 parallel pipes, install in center of configuration, and not adjacent to or touching any pipelines. The Construction Engineer will assist in positioning reference electrodes if required.

3.2.4.3 Bring lead wire to top of hole for termination in test station and install wire marker with words: REFERENCE ELECTRODE.

3.2.4.4 Repair damaged lead wire insulation using conductor splice kit.

3.2.4.5 Backfill in accordance with Section 02225 .

3.2.5 Pipe Test Conductors, Bonding Jumpers and Negative Return Cables

3.2.5.1 Existing pipes

a. Before work commences, have the Construction Engineer verify usage of each pipe to which conductors are to be connected. If pipes are coated, cut window in coating large enough to accommodate exothermic weld mold. Wire brush each pipe and file to bright metal surface, free of $0 i 1$ and dirt. Make exothermic welds of conductors to pipe in accordance with approved manufacturer's instructions, or use ground clamp connectors on nonprotected piping as directed by the Construction Engineer. If ground clamp connectors are used, coat connections using the same materials and installation methods as for exothermic welds. Install bonding jumpers across mechanical pipe joints (such as threaded 
couplings or bell and spigot connections) that have test conductors Page 118 attached with No. 4 AWG copper wire and exothermic welds. Extend bonds to a point 50 feet from the nearest anode.

b. After weld is made, test integrity of connection by tapping side of weld material with hammer. If weld fails, make another weld at least 3 inches from previous attempt.

c. Document pipe test conductor exothermic welds recording identification of test station, pipe identification, and performance of an acceptable visual examination and integrity test.

4. At pipe-connection, apply-clear-RIV-silicone-seałant-on exposed-copper wipe, weid-material and-bared pipe. Overtap-seatant on-copper-wipe-insulation, on any pipe couting op on bared pipe-a minimum of 1 - inch. Smooth-seatant by hand.

d. At pipe connection, apply liquid epoxy coating on exposed copper wire, weld material and bared pipe. Overlap coating on any pipe coating or on bared pipe a minimum of 1 inch. Wrap exposed copper conductors with electrical splice insulating tape and plastic insulating tape.

e. Conductor size specified on the Drawings.

f. Repair damaged pipe test conductor insulation with 2 half-1 apped layers of electrical splice insulating tape and 2 half-lapped layers of plastic insulating tape.

g. Make repairs of foam insulation on pipe with sprayed polyurethane as follows. procedure.

1) Install in accordance with manufacturer's recommended

2) Side-wall retainer may be used to assure uniform width and height of sprayed insulation. Obtain approval of retainer wall installation and materials from the Construction Engineer.

3) Repair opening in flexible duct liner with plastic sheet material similar to existing.

h. Identify the end of each conductor using specified wiremarker with typewritten or imprinted pipe number to which conductor is connected. Label pipe test conductors connected to unidentifiable pipes with pipe size followed by words "U. G. LINE."

i. Use terminal lugs for conductor terminations in test station.

j. Backfilt in accordance with Section 02225.

\subsubsection{New pipes}

a. Wire brush each pipe conductor standoff bracket and file to bright metal surface, free of $0 i 1$ and dirt. Make exothermic weld of conductors 
to standoff bracket in accordance with approved manufacturer's

HNNF-2532, Rev. 0 instructions. 
b. After weld is made, test integrity of connection by tapping side of Page 120 weid material with hammer. If weld fails, make another weld.

c. Document exothermic welds as follows:

1) Pipe test conductors: Identification of test station, pipe identification, and performance of an acceptable visual examination and integrity test.

2) Bonding jumpers and negative return cable: Pipe identification and performance of an acceptable visual examination and integrity test.

4.-Apply-CTeap-RTY silicone-seatant on-exposed-eopper-wipe, weld matepial and baped conductor standoff bracket Overiap seatant on coppep wipe instlation, on-any pipe-coating op on bared surface-a minimum-of 1 infh. Smooth-seatant-by hand.

d. Apply liquid epoxy coating on exposed copper wire, weld material and bared conductor standoff bracket. Overlap coating on any pipe coating or on bared surface a minimum of 1 inch. Wrap exposed copper conductor with electrical splice insulating tape and plastic insulating tape.

e. Conductor size specified on the Drawings.

f. Repair damaged pipe test conductor insulation with 2 half-lapped layers of electrical splice insulating tape and 2 half-lapped layers of plastic insulating tape.

g. Identify the end of each conductor using specified wiremarker with typewritten or imprinted pipe number to which conductor is connected.

h. Use terminal lugs for conductor terminations in test station.

i. Backfill in accordance with Section. 02225.

3.2.6 Conductors: Install anode header, anode loop, and negative return cables as follows:

3.2.6.1 Place in trenches prepared in accordance with the Drawings.

3.2.6.2 Identify cables, using specified wiremarkers, at terminations except at inaccessible underground locations. Nomenclature shall be as shown on Drawings.

3.2.6.3 Terminate anode header and anode loop cables at anode junction boxes. Use terminal lugs for conductor terminations. Coil negative return cable and anode header, and loop cables at the future rectifier Tocation.

3.2.6.4 Repair damaged cable insulation by using conductor splice kit.

3.2.6.5 Cover cable ends with plastic electrical tape until ready for termination. 
3.2.6.6 Cable marker: Install as noted on Drawings. 
3.2.7 Conduit: Install underground power conduits where shown on the Drawings. Cut conduit square, ream and deburr. Repair damaged PVC coating on conduits with touch-up compound. Seal conduits that enter control panels or boxes with duct sealing compound.

3.3 FIELD QUALITY CONTROL

3.3.1 Testing, General

3.3.1.1 Furnish instruments and equipment required to conduct testing.

3.3.1.2 Use test instruments which bear valid calibration stamps showing date of calibration and expiration dates of stamps. Calibration and accuracy of test instruments shaT1 be certified by an independent testing laboratory having standards traceable to the National Institute of Standards and Technology.

\subsubsection{Wiring Systems}

3.3.2.1 Test wiring operating less than $150 \mathrm{~V}$ to ground for continuity and unintentional grounds.

3.3.2.2 See Appendix A for Functional Test of Reference Electrodes. 


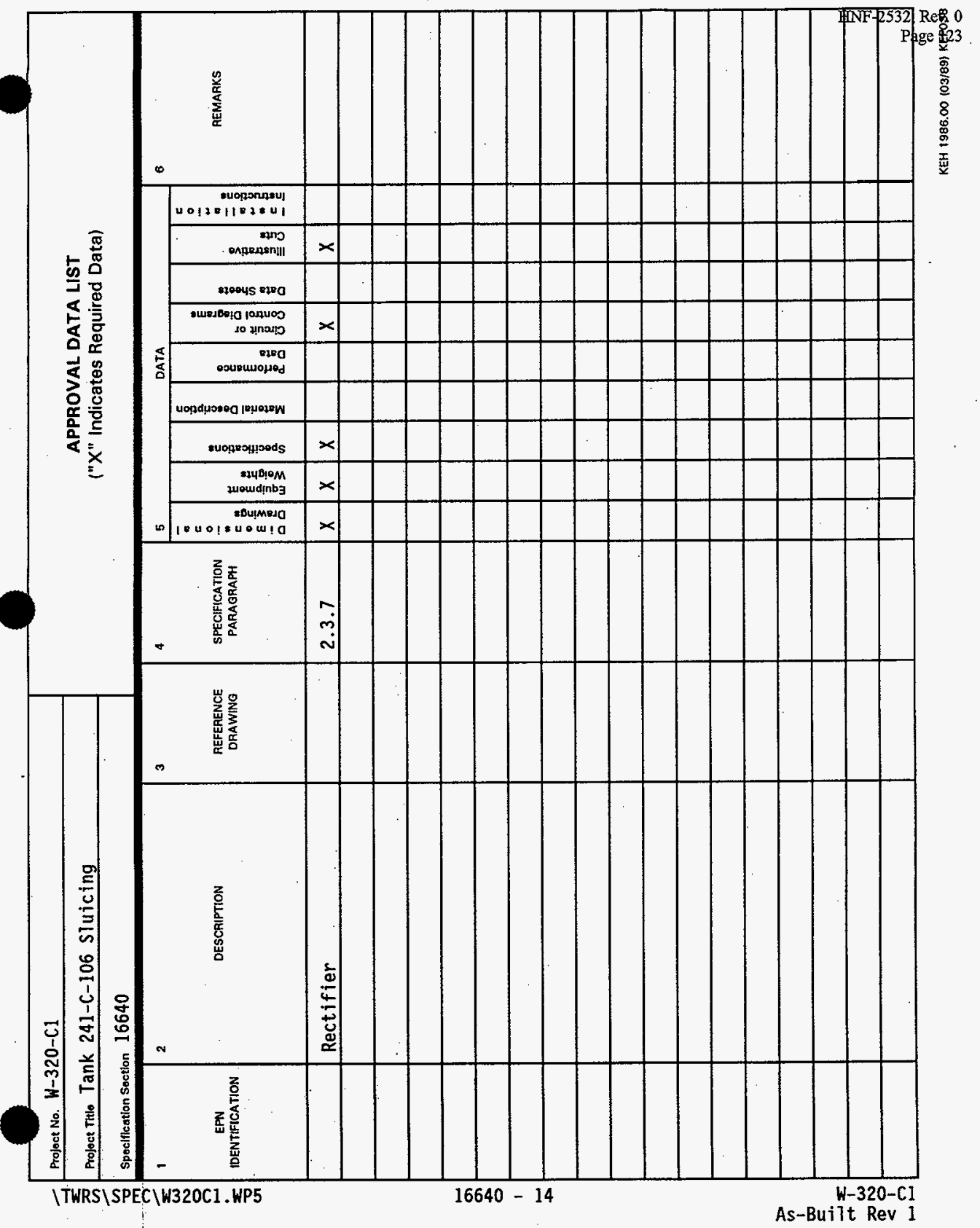




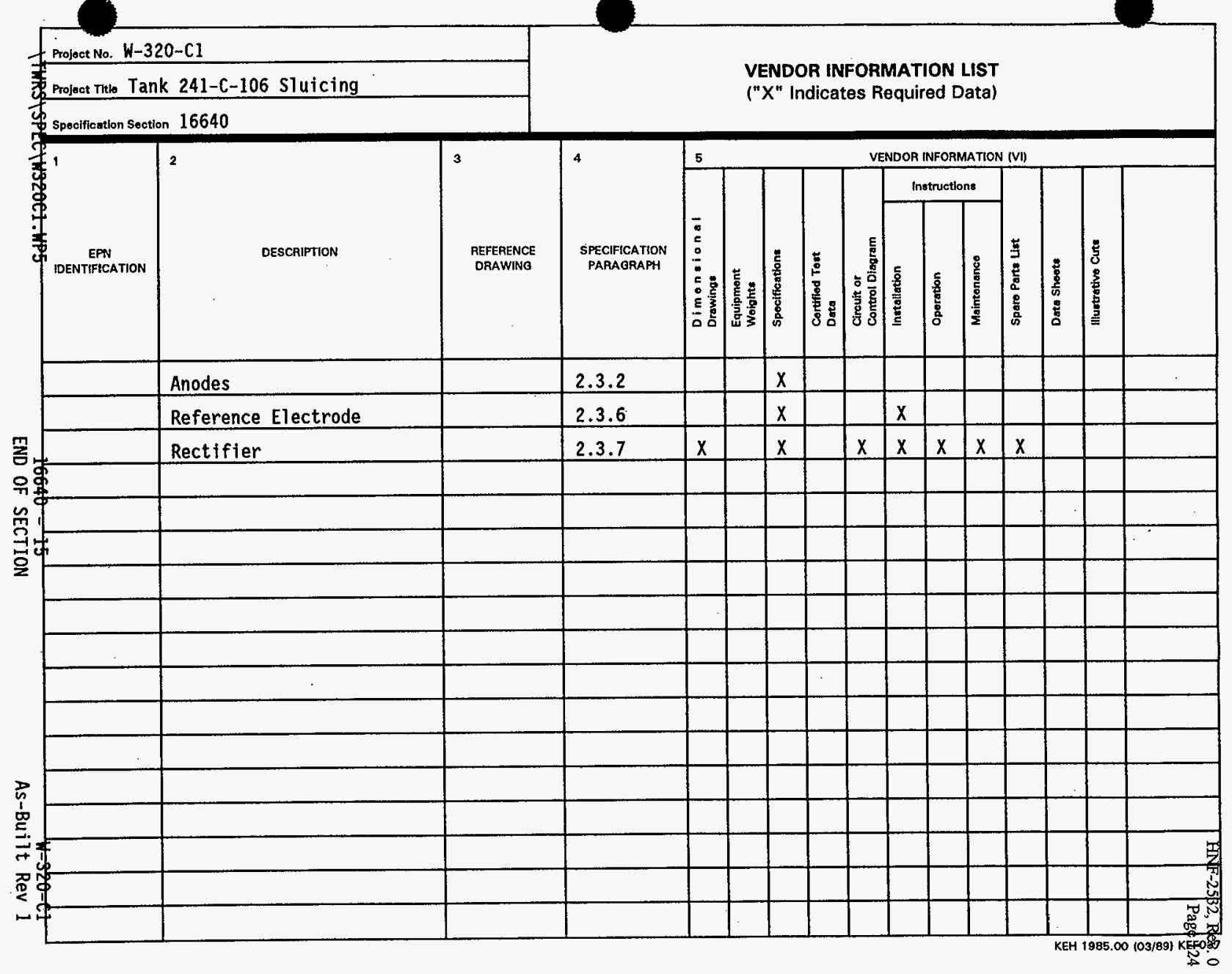




\section{FUNCTIONAL TEST OF REFERENCE ELECTRODES}

Test each new permanent underground reference electrode just prior to installation in earth as follows:

1. Place the permanent reference electrode to be tested in a plastic bucket filled with tap water and soak for at least 3 hours:

2. Use an M.C. Miller, Model RE-5 portable reference electrode that has been tested for accuracy (see method below). Place end in the water in the plastic bucket or touch end of portable reference electrode to outside bag of permanent reference electrode.

3. Using a digital voltmeter, measure the voltage between the two reference electrodes and verify that the value is less than $50 \mathrm{mV}$.

4. If difference is equal to or greater than $50 \mathrm{mV}$, discard and replace tested permanent reference electrode with another and repeat steps 1 through 5. Record the results on the data sheet.

5. Report deficiencies to the Construction Engineer.

Accuracy Test: Place end of two M.C. Miller, Model RE-5 portable reference electrodes in a plastic bucket filled with tap water. Using a digital voltmeter, measure the voltage between the two reference electrodes and verify the value is less than $2 \mathrm{mV}$. Drive a 3 foot section of No. 4 or 6 steel reinforcing rod vertically into the earth leaving approximately 3 inches above grade. Using a digital voltmeter, measure the voltage between the rod and one of the portable reference electrodes placed on the ground approximately 3 feet from the rod. Record voltage: . Repeat same test using second portable reference electrode. Record voltage Verify difference is less than $50 \mathrm{mV}$. Utilize either one of these reference electrodes as the portable reference electrode in the test above. 
HNF-2532, Rev, 0

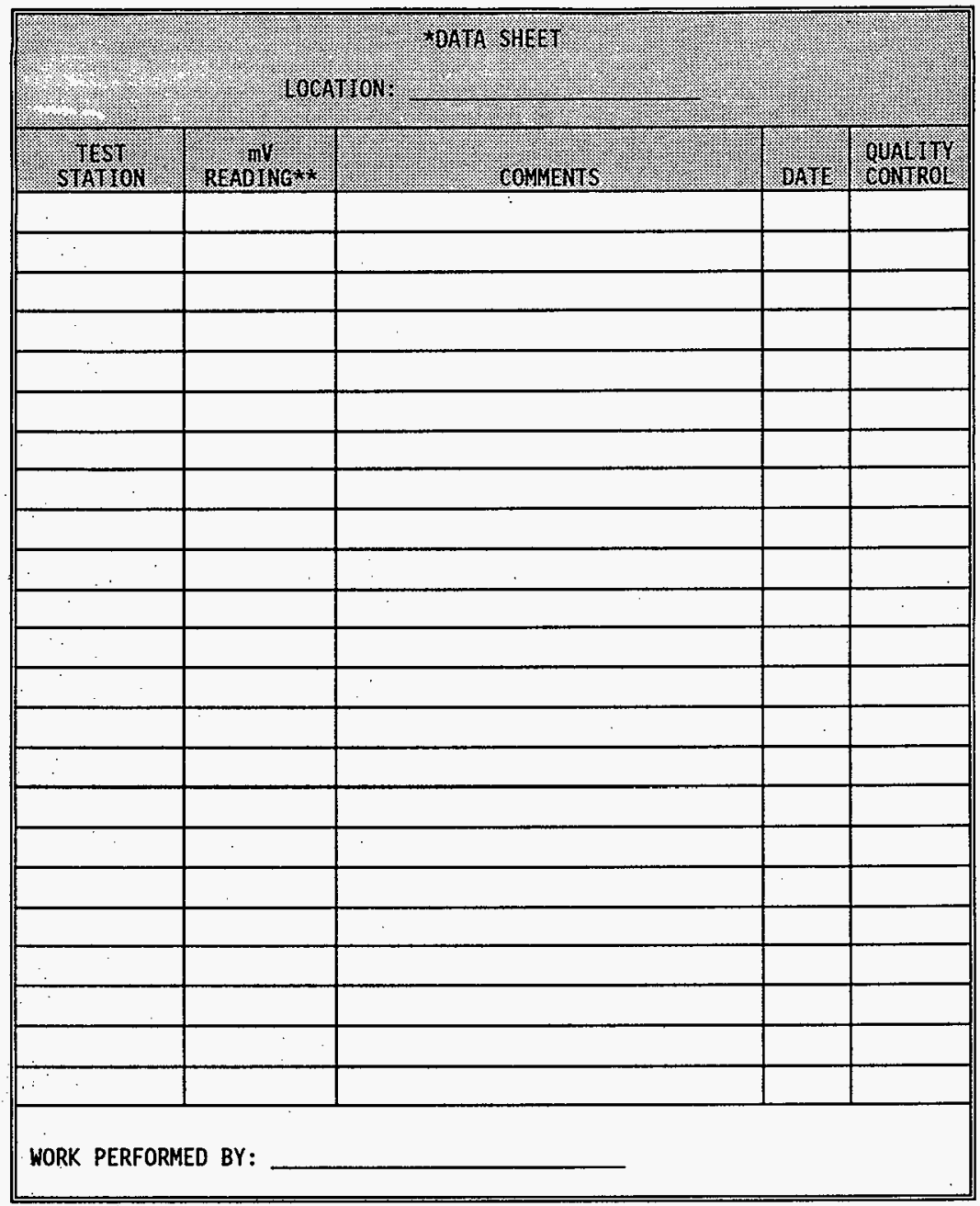

NOTES: *0btain additional sheets from the Quality Control Inspector. **Between Portable Reference and Permanent Reference Electrodes

END OF APPENDIX 


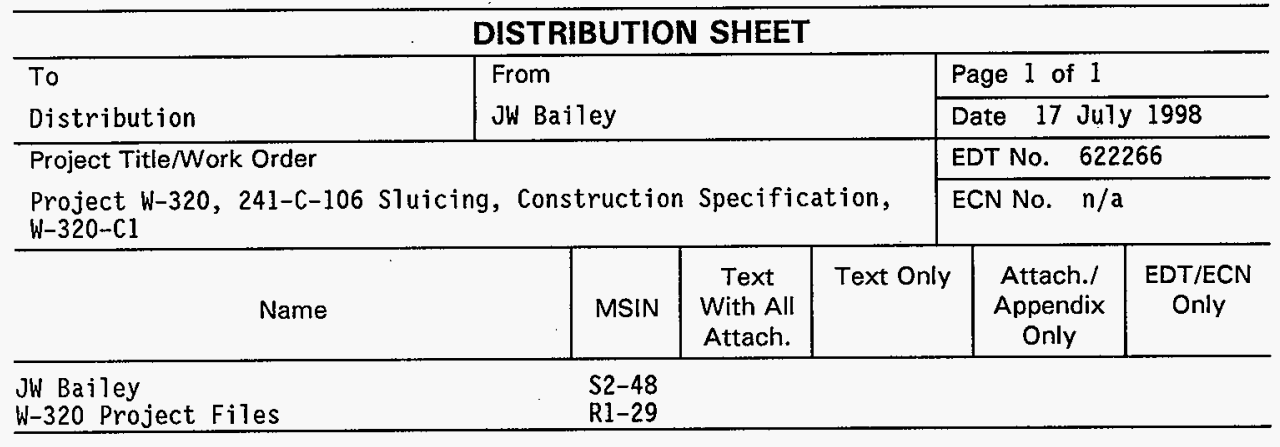

